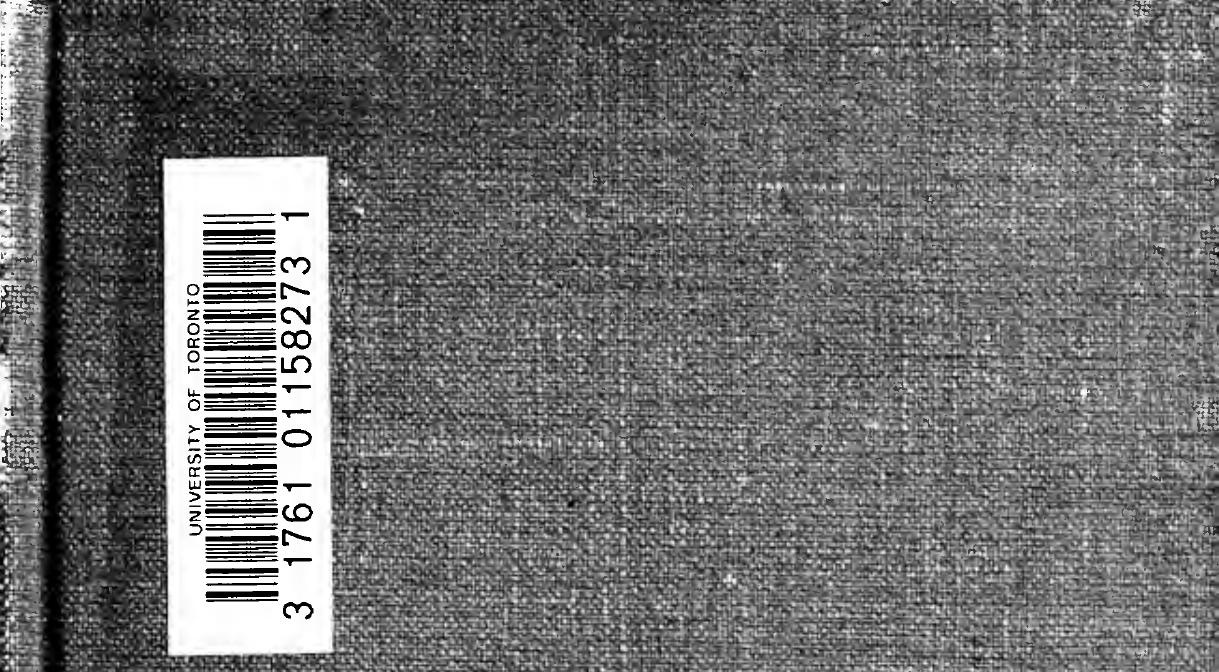

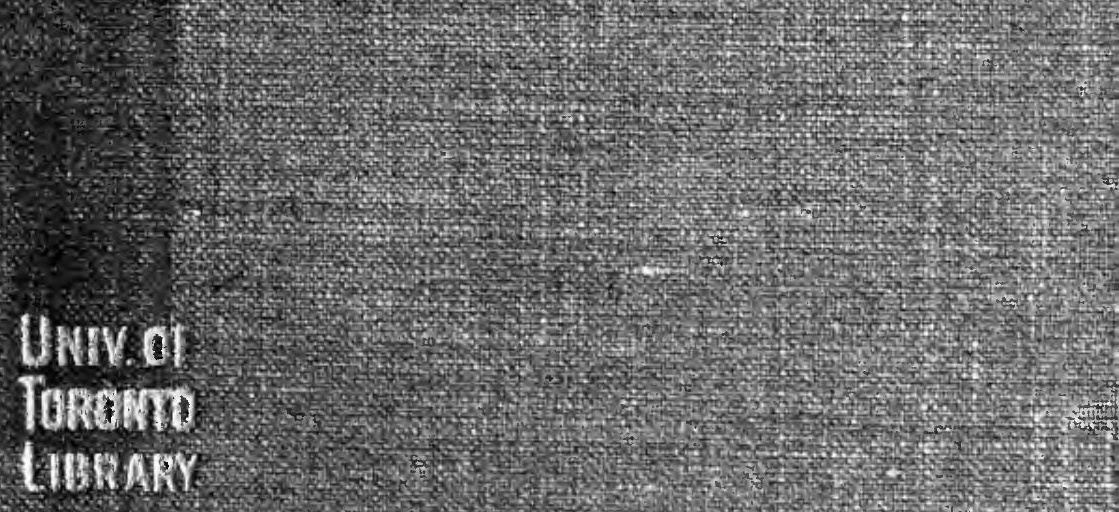

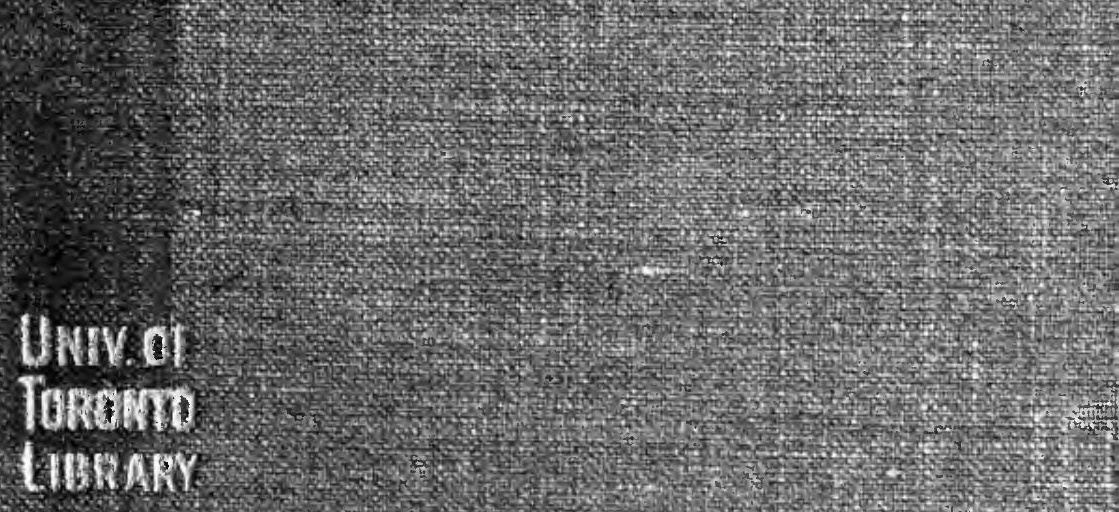

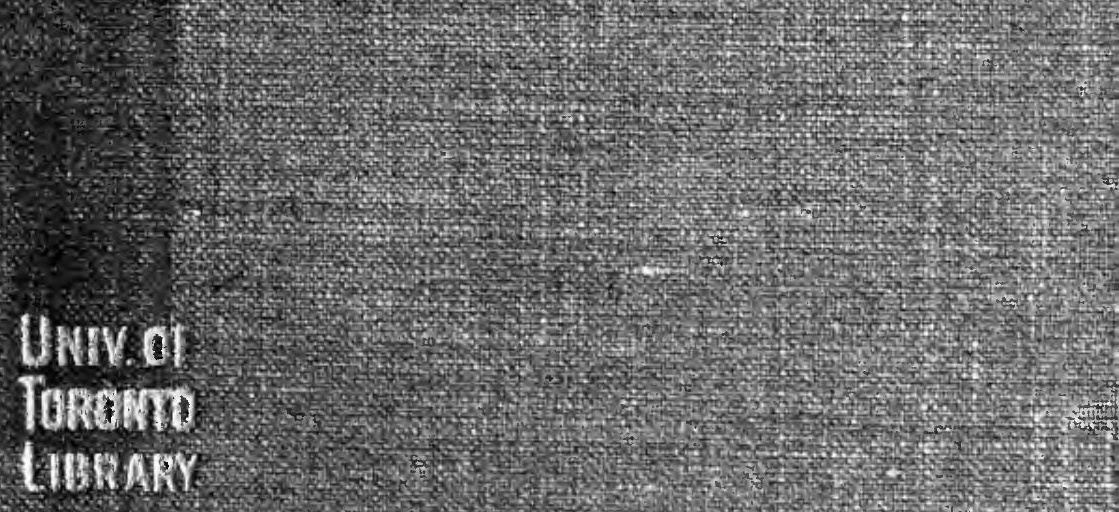

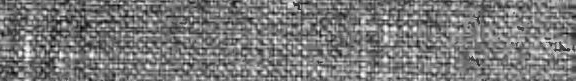




Digitized by the Internet Archive in 2011 with funding from University of Toronto 
A RABBINICAL COMMENTARY ON THE

\title{
BOOK OF PROVERBS
}

\author{
DRIVER
}


Ilonon

HENRY FROWDE

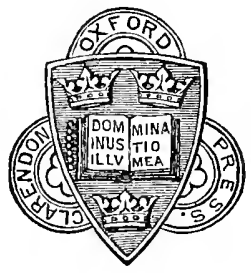

OXFORD UNIVERSITY PRESS WAREHOUSE

7 PATERnOSTER ROW 


\title{
A COMMENTARY
}

\author{
ON THE
}

\section{BOOK OF PROVERBS}

ATTRIBUTED TO ABRAHAM IBN FZRA

EDITED

FROM A MANUSCRIPT IN THE BODLEIAN LIBRARY

BY

S. R. DRIVER, M. A.

Fellowe of tiew College, axford

Q 1 *ford

AT THE CLARENDON PRESS

M ICCC LXXX

[All rights reserical] 



\section{PREFACE.}

FOR some years past it has been generally admitted "that the Commentary upon the Proverbs of Solomon, printed in the Rabbinical Bibles under the name of Ibn Ezra, is in truth not from his hand, but is the work of Hoses Kimchi, brother, uf the more celebrated David Kimchi. The merit of having first recognized this belongs to Jacob Reifmann, a born critic $^{2}$, whose native genius enabled him to overeome great disadvantages of birth and position, and who has since made himself known as the author of a series of acute suggestions on the text both of the Old Testanent itself and of later Jewish writings ${ }^{3}$. This scholar, in $18+1$, communieated the opinion which he had formed to Abraham Geiger, at the same time drawing his attention to the internal evidence supporting it; and a short account of the correspondence between them appeared in the Hebrew periodical Zion for $18+1, p \cdot 7^{6}$. In the Orient for the same year, p. $75^{\circ}$, Reifmam indicated more explicitly the nature of the grounds by which he had been guided, pointing out, for example, that certain grammatical expressions occurring in the Commentary are not those employed by Ibn Ezra (e.g. 'מושך שים עמו, בלומ, the introduction

${ }^{1}$ Friedländer, Essays on the Writings of Abraham Ibn Ezra (I8;-), p. I4 2 .

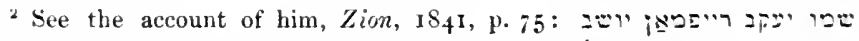

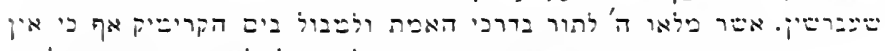

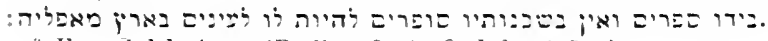

3 E. g. Suleh Aram (Berlin, 18;1), Or boker (1879). 
of a biblical quotation by שנ:מר); and that the exegesis also is such as frequently to contradict the opinions of Ibn Ezra as expressed elsewhere. In the following year the question was taken up by another student of Ibn Ezra's works, Gabriel Hirsch Lippmamn, who, in a series of articles published in the same periodical $Z$ ion ( 1842 , pp. I I 3 , I 29, I 55, I 7 I , I85), demonstrated, in greater detail than had been attempted by Reifmarn himself, the truth of the conclusion at which he had arrived ${ }^{1}$. Of these articles, the two first shew that, both grammatically and lexically, the views expressed by the author of the Commentary are at variance with those held by Ibn Ezra to an even greater degree than had before been supposed: the third adds largely to the number of grammatical terms peculiar to this Commentary, but unknown to the gennine works of Ibn Ezra: while in the two remaining papers additional reasons are brought forward in support of the opinion that the actual author was Moses Kimchi. That this opinion is correct there can indeed be no doubt. Not only (as Lippmann remarks, p. I72) are there numerous resemblances in style with the Commentaries upon Ezra and Nehemiah which, though similarly ascribed to Ibn Ezra, are known (from the acrostic at the beginning) to be the work of Moses Kimchi, but David Kimchi, in his Book of Roots, s.v. שגה, cites expressly, under the name of his brother Moses, an interpretation of Prov. 5, 19, agreeing verbally with that which is given in the printed Commentary. And, more recently, MSS. have been discovered assigning it to him distinctly ${ }^{2}$.

1 Comp. his words, p. II3: מרי צברי על ספרי החכם הגרול רבי אברהם

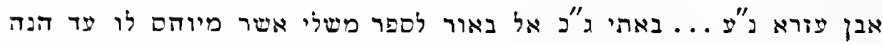

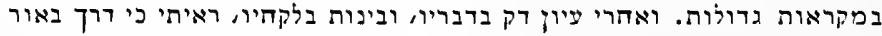

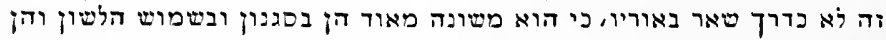

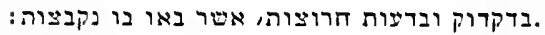

2 See Leopold Dukes, Orient, 1847 , p. 25 f. ; A. Berliner, in the periodical Jeshum (edited by Kobak), I868, p. I02 : comp. also Geiger, Ozar Nechmad. ii. $(1857)$, p. 2 I f. 
That Ibn Ezra composed a Commentary upon the Proverbs is certain: not merely (on Ruth 3, r I) does he promise to

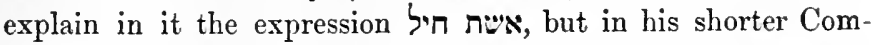
mentary on Exodus (Prag, I840, p. 96) he remarks 'משלי פרשתי ההפרט בין חבמה ורעת ותבונה of his other Commentaries, like those on the former Prophets, on Jeremiah and Ezekiel, on the Chronicles ${ }^{2}$, it must at an early date have become lost, while-as in the parallel case of Ezra and Nehemiah-that of Moses Kimchi obtained circulatiru under his name. Nor, strangely enough, is this the only one which was substituted. For, as was noticed by Geiger ${ }^{3}$, Raymundus Martini, in his Pugio Fidei, written about the year. I275, cites, under the name of Ibn Ezra, expositions of two passages (Prov. 2, 7 and $\mathrm{I}$ 4,34) which in fact are found verbatim in the Commentary of Joseph Kimchi, the father of Moses and David Kimchi. The extracts in Martini read as follows:

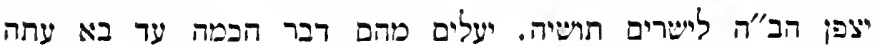

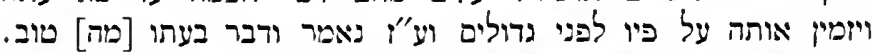

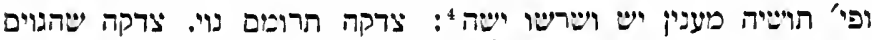

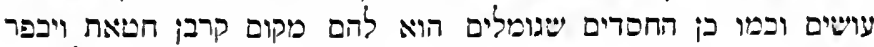
: עליהם. These words are not to be found in the Commentary of Moses Kimchi attributed to Ibn Ezra in the Rabbinical Bibles, nor, it may be added, are they in the Commentary here published; lut both passages occur in the Commentary on Proverbs by Joseph Kimchi ${ }^{6}$. And to the two works which were thus independently mistaken for the lost Commentary-

${ }^{1}$ Cf. Halberstan, Sepher Ha-ibbur (Lyck, I874), p. 8.

${ }^{2}$ Friedländer, Essays, etc., p. I 42.

- Ozar Nechmad, l. c., p. z3.

4. P. 666 (ed. Le Voisin); p. 855 (ed. Carpzov).

5. P. 79 (ed. Le Voisin); p. 925 (ed. Carpzov).

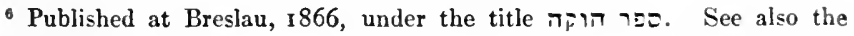
MS. in the Bod!eian Library (Neubauer's Catalogue, No. 333), pp. $2^{\text {b }}, 13^{\text {a }}$. 
one of them within little more than a hundred years of Ibn Ezra's own death - must now be added a third.

The MS. containing the Commentary here published (Opp. Add. 8o. 48 , Catal. No. 2487 ) belonged formerly to M. Soave, of Venice, from whom it was obtained by Dr. Neubauer, at the beginning of the present year, for the Bodleian Library. It is a paper MS., ff. I 7 , of large octavo size, written in the Italian Rabbinic character, and belonging probably to the sixteenth century. Ff. $\mathrm{I}-5^{\mathrm{a}}$ are occupied by Moses Kimchi's Commentary on Ezra and Nehemiah ${ }^{\mathrm{r}}$ ff. $5^{\mathrm{b}-\mathrm{I}} 7^{\mathrm{a}}$ claim to be that of Ibn Ezra on Proverbs: the title (it should be remarked) being evidently in the same hand as the rest of the MS. It is neatly and legibly written: the corners of the leaves are occasionally somewhat injured by damp, but in no instance has there been any serious doubt as to the reading, except, indeed, in cases such as those between $工$ and 2,7 and $7, v$ and 19 , etc., from which, probably, no Hebrew MIS. was erer entirely free. All abbreviations have been faithfully reproduced, except that for the Tetragrammaton, which is uniformly written $6 . \therefore$. A word, or letter, missing has been supplied, in the text itself, between brackets; misquotations and other obvious faults have been as a rule corrected in the text likewise, the MS. reading being indicated in a note; a few irregularities (chiefly of gender) have been suffered to remain ${ }^{2}$, and some passages have been left untouched, in which, however the sense might be difficult or obscure, the MS. was unmistakeable ${ }^{3}$. For the punctuation I am exclusively responsible, as also for the frequently recurring dots, which indicate, for the convenience of the reader, that

1 Attributed, howerer, to Ibn Ezra, as in the printed Bibles.

2 E.g. 4, 33. 14, 25. 20, 25 היה ראי 31, I5. 24.

3 E.g. I 2, 25. 14, 26 היא. I5, 2 end. 16, 24. I7, I 2. I8, 8. 20.2 I, I6. 22, 5; 8, I8 ארות seems supported by 8, 30. 16, 7 end. The plena scriptio also is very general, even in such words as אוניה

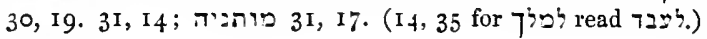


a text is not cited continuously, but which represent no mark of omission whatever in the MS.

The Commentary, then, purports to be the work of Ibn Ezra : and although the internal evidence, as a whole, fails to support this claim, yet, as it does not point entirely in one direction, I may be allowed here to recapitulate it briefly in some of its more obvious bearings.

That the promise given in the note on Ruth 3 , I I is unfulfilled is of no great moment; for. Ibn Ezra is guilty of similar omissions elsewhere ${ }^{1}$ : it is a more serious difficulty that in none of the three passages $(2,7.3,19 \mathrm{f} .24,3 \mathrm{f}$.) where דעת are found in juxtaposition is any distinction. drawn between them, such as the one referred to in his note on Ex. 31, 3. Secondly, some of the identical expressions are made use of (notably ' 2 , כלומ', which are objected to by Reifmann and Lippmann equally, in their criticisms on the printed Commentary, as not occurring in the acknowledged writings of Ibn Ezra. Thirdly, as the following list will shew, instances are not wanting, in which the interpretations diverge, more or less widely, from those given by Ibn Ezra in other

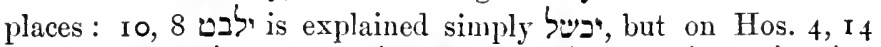

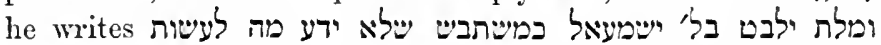

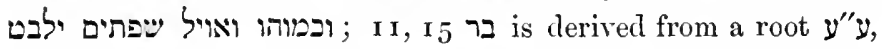
whereas on Ps. 2, I2 such a view is rejected; with the note on 14,13 comp. on Ps. 84, 4 גם כמו גם בישחוק יבאב לב שטמו

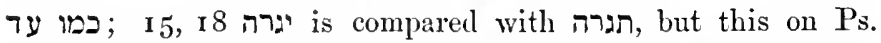

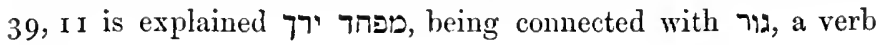

1 See Isa. 26, 4; and comp. Friedländer, Essays, p. г 36.

${ }^{2}$ One or two other formulae often recurring here are ... והכל שפבין;

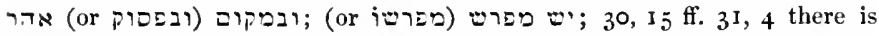
als? the phrase ריכת אריכוה. A singular use of in cases where $E$ would naturally be expected (unless this is to be attributed to a copyist), may also be noted: 3, 21. 14, 23. I5, 23. 20, 5. $21,5.14 .24,15.31 .25,20.26,21$. $30,13 \cdot 31,15$. 
I'ע; $15,22^{b}$ - the standard example ${ }^{1}$ of Ibn Ezra's principle that every form of the verb involves implicitly, though it may not be expressed, the corresponding verbal noun-we are surprised to be told to supply מחשבת, rather than word used elsewhere; I6, 6 the alternative פו פעול comes strangely from the author of Zachoth, 58 עוצומים is interpreted with reference to men, but on Isa. 4 I, 2 I we read עיפומותיכם כמו ריבכם ובן ובין עצומים יפריר; 23, 5 in support of the meaning Job II, I7 is referred to, where, however, we read תעופה י"א תסתכל וכיך

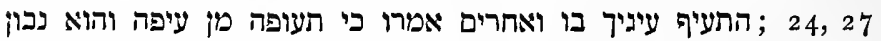

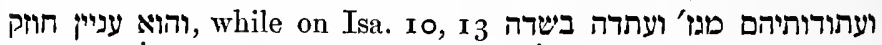
לד הממון שיומן הארם ישימציאנו לעתיר מימיו ; with the notes on 24, 28 והפתית comp. Moznaim (Venice, r546), pp. $2 \mathrm{IO}^{\mathrm{b}}, 229^{\mathrm{a}} ; 28, \mathrm{I}$ יבת מרת appears to be referred to כפיר, although Ibn Ezra more than once elsewhere actually quotes the verse in illustration of the construction ואורריך ארור , ואוכליו עונו ישור (Lev. I9, 8. Num. 24, 9) ; 29, I 8 יפרלך לאחור is explained, but on Ex. 5, 4 (shorter Comm.) he interprets למה תשנו, and on

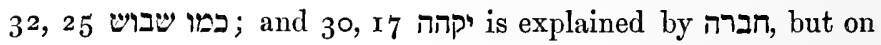
Gen. 49, Io by משמעה. It may be remarked that frequently the Commentary agrees with that of Joseph Kimchi : e.g. 6, 2 I. I 2, 27. I 8, I9. 20, II ${ }^{2} .25,20.26,8$.

Doubtless, to a certain extent, these objections might be met. With regard to the first, it might, for instance, be thought that the Commentary is not before us in its original shape: the notes on the earlier chapters seem disproportionately brief as compared with those on the later portions of the book, and an omission must certainly be assumed between 27,9 and 27,26 . Or, again, Ibn Ezra himself, having in his mind, as he wrote

1 E. g. on Isa. $7,7 \cdot 5^{6,2} ;$ Zachoth (Fürth, 1827 ), p. $71^{\mathrm{b}}$; see Friedländer, p. $\mathrm{x} 34$.

${ }^{2}$ See David Kimchi, Book of Roots, s.v. נכר. 
his note on Exodus, a clear sense of the difference between the three terms in question, and recollecting how they occurred together in the Proverbs, might be supposed, not unreasonably, to have been under the impression that he had distinguished them in his Commentary on that book more explicitly than was actually the case: we know that he wrote hastily, and quoted habitually from memory ${ }^{1}$. Secondly, it might be urged, that Ibn Ezra is not everywhere uniform in his terminology, that expressions which are of frequent occurrence in one Commentary are met with seldom or never in another ${ }^{2}$; and that, though there may be two or three exceptions, most of the grammatical terms, including some characteristic ones (see below), are unquestion-ably those which he was accustomed to employ. Thirdly, on points of philology, as most readers will have observed, Ibn Ezra is far from being uniformly consistent with himself: and cases have even been quoted in which at one time he adopted a view which at another he had emplatically rejected ${ }^{3}$. Does not this consideration, it might be asked, weaken materially the conclusiveness of the list of discrepancies which has been cited above? And indeed, as a matter of fact, if it be examined in detail, the cogency of several of the instances will be found to be very slight. Thus, with reference to 10,8 the Commentary on the Proverbs was composed many years earlier than that on the Minor Prophets, at a time when the Arabic parallel for לבט might not yet have suggested itself to Ibn Ezra; $\mathbf{5}_{5}, \mathbf{1} 8$ if the note on Ps. 39 be inconsistent with that on Prov. 15 , r8, it is inconsistent also with that on Deut. 2, 5, where תת is not compared with גור, but explained עניין תנועה ושבוש

1 Friedländer, p. 139. A similar case might be appealed to, occurring in the shorter recension of the Commentary on Exodus 32, 4; for the note on Isa. 8, I contains no adequate explanation of הרטי, such as it is there implied has been given.

2 Friedländer, p. I 5 I.

s Friedländer, p. I 39, to whose instances additions might be made. 
explanation is only in appearance divergent from that implied elsewhere: the עצה which is to form the subject of תום being in the first instance conceived by him precisely as the text here represents it, viz. as the object to ${ }^{-1}{ }^{1}:$ I 8 , I 8 the alternative in the note on Isa. 4 I, 2 m must not be forgotten ויתבן היותו מגורת עצום on Job $x x, x 7$ was not probably the one in which he finally acquiesced, for subsequently ${ }^{2}$ (on Ps. 90, Io ונעופה) he connects

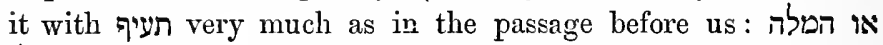
מגו' עפעף כמו תעופה כבקר תהיה התעיף עיעיך בו ואיננו ובאילו תעופה היו ימיפו. And the instances which remain might be thought to be not incapable of a fair explanation upon the same principle, even though the actual proof of a fluctuating exegesis on the part of Ibn Ezra were not in each separate case forthcoming.

But though particular arguments might thus be shewn to be inconclusive, there remain others the force of which cannot be evaded; and, taken as a whole, internal evidence forbids us to suppose that the Commentary is a genuine work of Ibn Ezra's. Not merely is there a combination of suspicious circumstances against it (and amongst them some which weigh seriously ${ }^{3}$ ), but the style is deficient in firmness, and in the exegesis we miss generally that terseness and point which is such a marked feature in Ibn Ezra's own writings. Who the

I See the note on Gen. 3, I 4 in the French recension published by Fried-

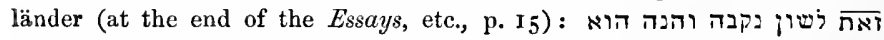

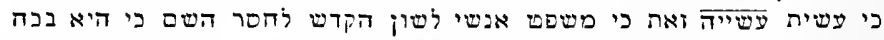

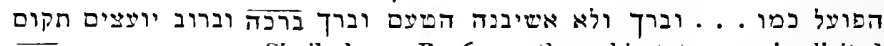

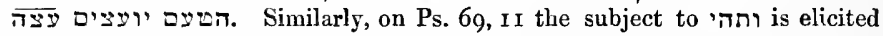
from the preceding ואבנה בכיה) בכיה ואביה (היתה להרפות לי (ה)

2 The Commentary on the Psalms is of later date than that on Job; Friedländer, pp. I75, 195 .

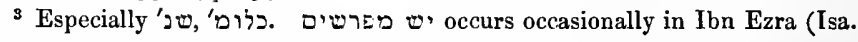
32, 17. 53, 9. Ps. 7, 1. Job 4, 2I); but he usually has שממרים'. 
author may be it is impossible to say, though, from the language in which, more than once ${ }^{1}$, he explains a Hebrew word, it may be inferred that he was a Spaniard. R. Yonah (Abulwalid) and Rashi are the only authorities cited by name ${ }^{2}$. Whether it is possible to draw any definite inferences from the points of similarity with the Commentaries of Joseph or Moses Kimchi, I do not venture to determine: as we learn from his son David Kimchi's note upon the passage, Jnseph Kimchi agreed with Ibn Ezra in supposing an ellipse before rמpur in $2 \mathrm{Sam} . \mathrm{I}_{3}, 20$. No positive grounds appear to exist for attributing to the author of the Commentary a fraudulent design : if it was his intention to personate Ibn Ezra, he at any rate neglected some obvious* precautions in carrying it out. The grammatical expressions which it has in common with Ibn Ezra suggest, indeed, that it was written by one familiar with his principles of interpretation, and even that it may embody genuine fragments of his exegesis (handed down traditionally?); and the missing work itself being doubtless in request, this very fact may have caused it to be bona fide mistaken for it.

The following is a list of points of agreement which I have noticed between the Commentary here published and those of Ibn Ezra; a few are included to which the reader will find his attention directed in the foot-notes. On 2, 22 we meet with an illustration of one of Ibn Ezra's best known grammatical principles; 5,5 are cited two of his regular examples for the omission of $\beth^{3}$; with the notes on 5,20 and $\mathbf{I}, 17$ compare those on Ps. 7, I. 78, 20 respectively; 7, 20 the explanation of agrees with that given by him on Ps. 81, 4, where, after

1 On 6, 3. I3. 23,32 .

2 Appeal is constantly made to the sense borne by a word in Aramaic, and passages from the Targums are quoted in proof : Arabic is referred to but rarely.

${ }^{3}$ Friedländer, p. $3_{32} 2^{2}$ : see also Gen. 3, I $_{5}$, French recension, and Zachoth $7^{\text {I }}$ bottom. 


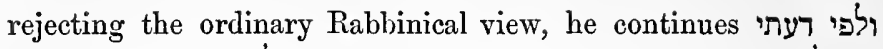
שמלת כסה כמו זמן קבוע או מוער ירוע וכבה ליום הבסא יבוא ביתו 7, 22 comp. Isa. 3, 16; with the note on 8, 23 comp. that on Ps. II9, I00 (יותר מהזקנים: : so Zachoth 28b), and more especially

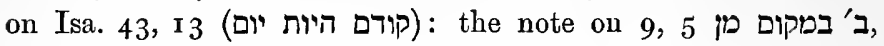
although as referred to on Ps. 22, 8 the $ב$ would be explained differently (דרך צחות: cf. also on 55, 19. 80, 6), expresses nevertheless a view held by Ibn Ezra (Zachoth, p. $15^{\text {a }}$ (כמו והנותר בבשר ובלחם 14,7 the explauation of Gen. 49, 25

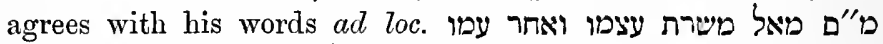
(cf. on Isa. I5, וב"ית בראשיו ימשר אחר עמו כמ"ם מאל אמות אביך;

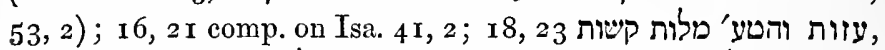

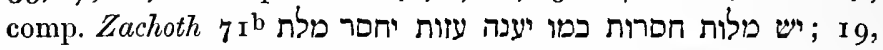
27 Ibn Ezra inclines towards the same interpretation in his

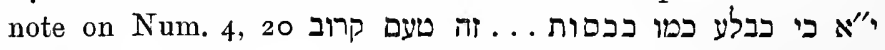
מהראשון; 20, 2 (cf. 19, I 2), comp. (though the expression is not

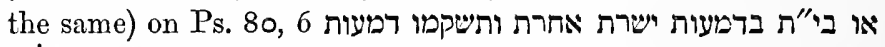
או 21, 2 comp. on Ex. I, Io (shorter Comm.) (אי תחסר מלת וצרה, and Zachoth $7 \mathbf{I}^{\mathrm{b}}$, where the passage

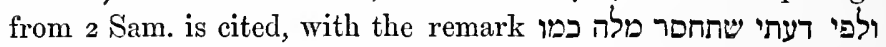
עצובה והדומה לה (cf. also $2 \mathrm{I}^{\mathrm{a}-\mathrm{b}} ;$ Saphah Berurah $3^{0^{\mathrm{a}}}$ ); 26,6 comp. on Hab. 2, 10; 26 , 18 agrees substantially with Sephath

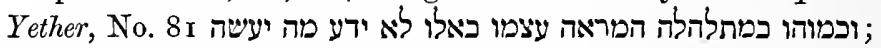

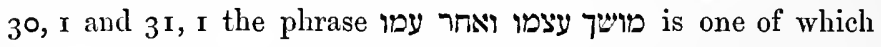
Ibn Ezra makes most constant use (e.g. Isa. 10, 34. 60, r $_{4}$. $65,2)^{1} ; 31,33$ מל מל 3 is explained from the Aramaic, as in אלקום ... במו אל לקום comp. on Isa. 24, 20 and Zachoth $5^{8 \mathrm{~b}}$ אנשי הדקרוק רק הוא שם הפועל כמו בידי לא אוכל קום

I have only, in conclusion, to record my obligations to Dr. A. Neubauer, Sub-Librarian of the Bodleian Library, whose wide and varied learning is always at the disposal of his friends,

1 Friedländer, p. I $3^{I^{3}}$. 
and who by his counsel and assistance has materially aided me in preparing this MS. for publication. Through him, also, the sheets, as they passed through the Press, have had the advantage of being submitted to Dr. Steinschneider, S. J. Halberstam, and Dr. Friedländer; and several corrections, suggested by them, have been incorporated into the text. Dr. Friedländer, I am at liberty to add, who has made Ibn Ezra's works his special study, expressed decidedly the opinion that this Commentary was not by his hand.

S. R. D.

August, I 880. 


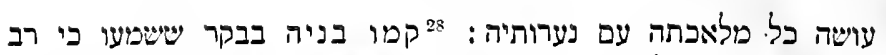

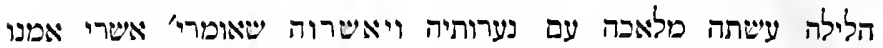

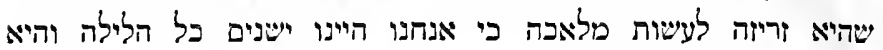

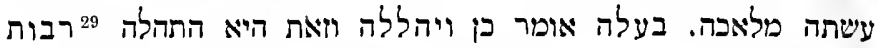

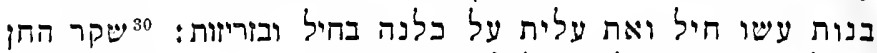

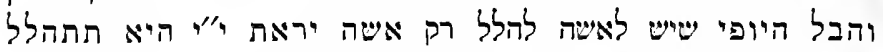

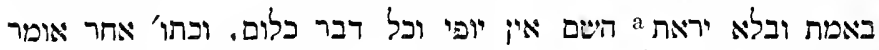

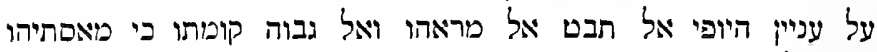

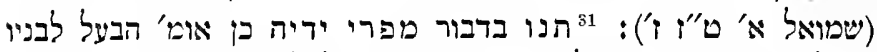

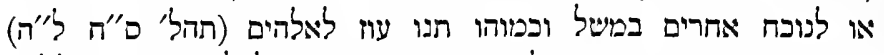

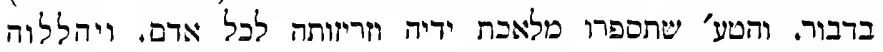

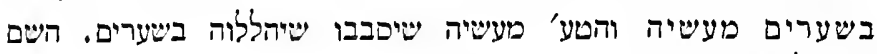
יינכנו לעשות מעים מעותיו:

בעזרת אל אדמה על

בריך רחמנא צואל
נשלם פירושי מישלי מעותי בלימה תולה פירה משי

דסייען אמן סלה

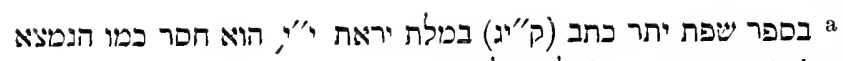

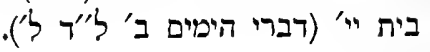




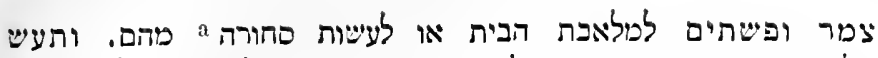

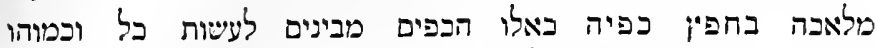

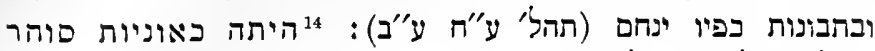

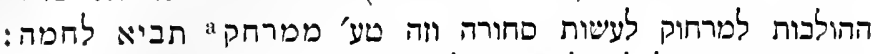

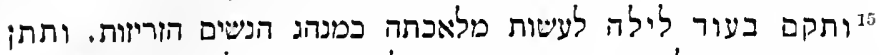

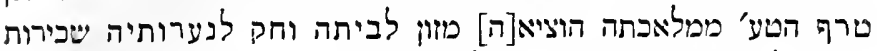

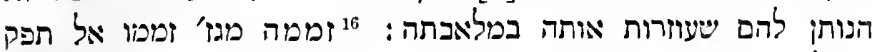

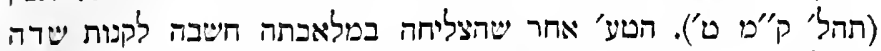

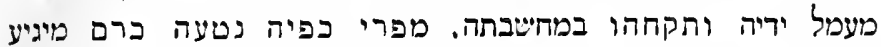

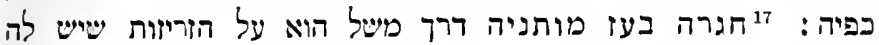

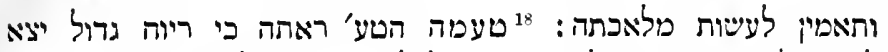

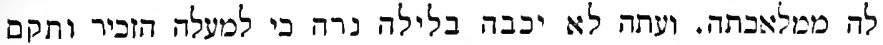

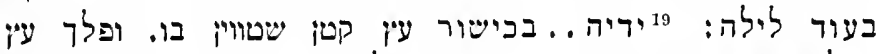

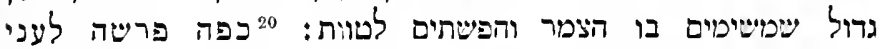

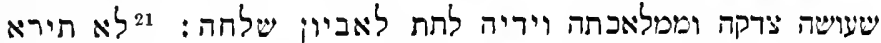

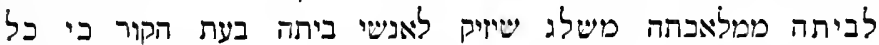

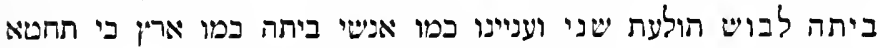

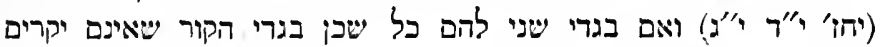

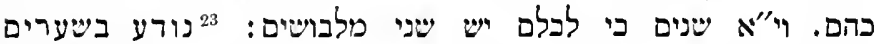

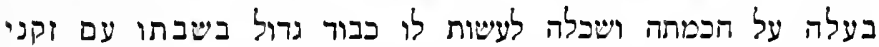

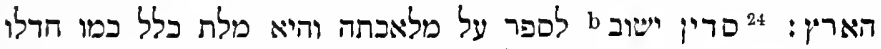

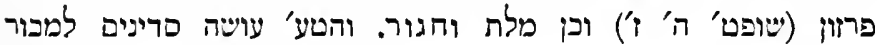

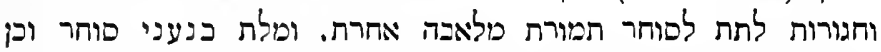

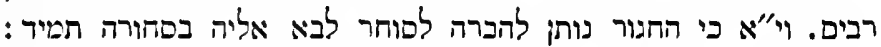

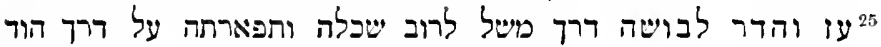

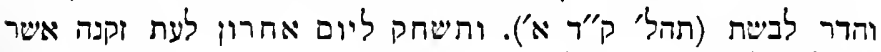

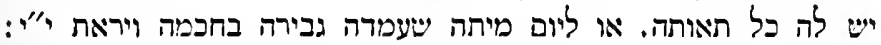

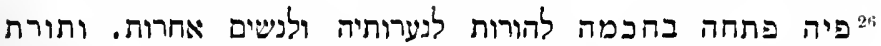

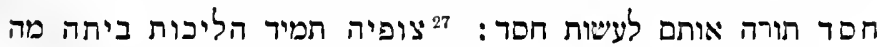

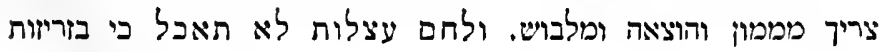




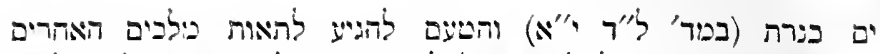

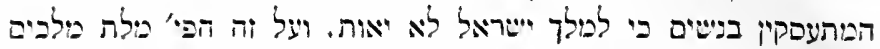

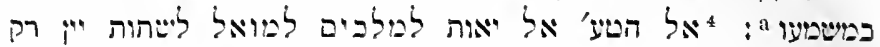

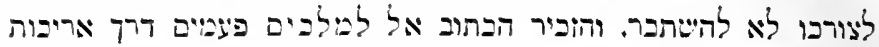

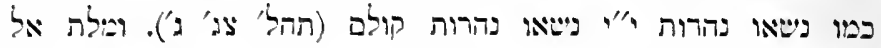

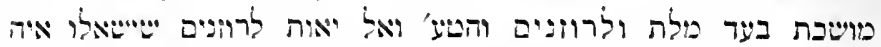

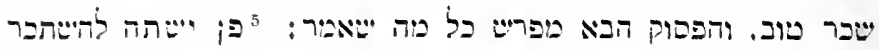

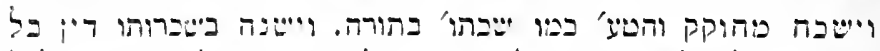

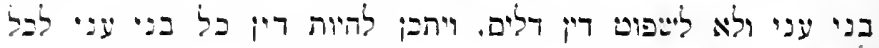

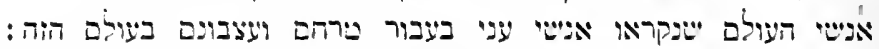

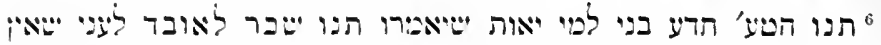

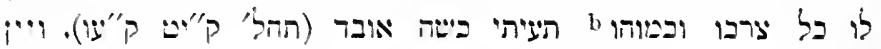

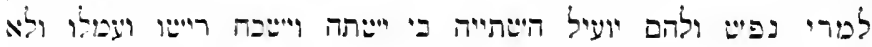

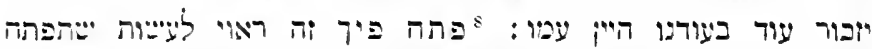

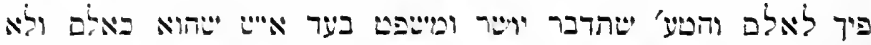

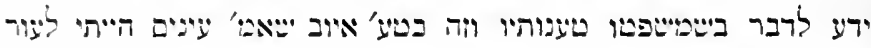

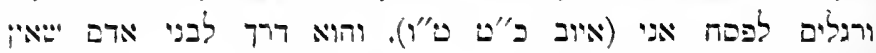

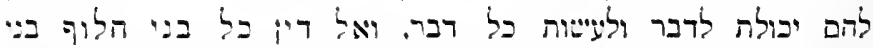

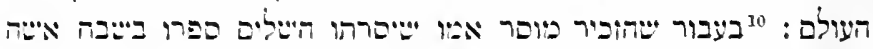

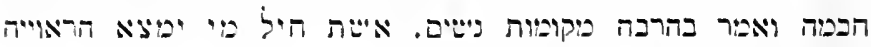

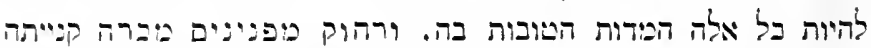

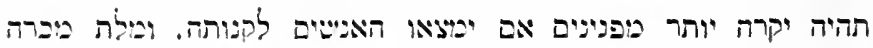

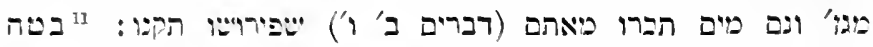

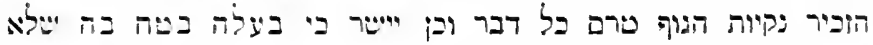

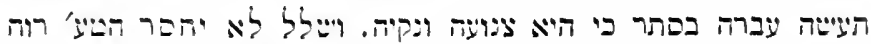

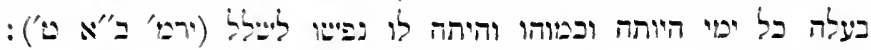

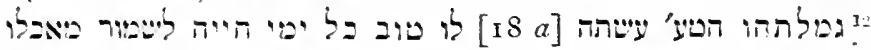

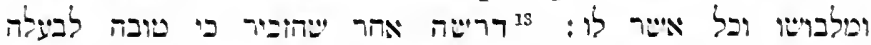

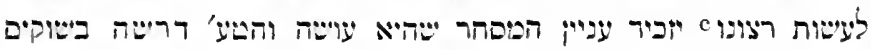

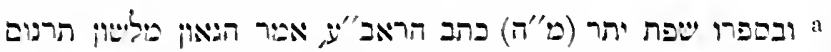

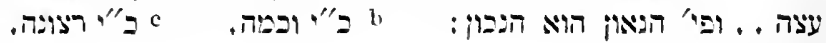




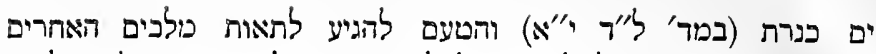

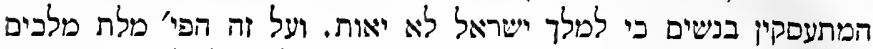

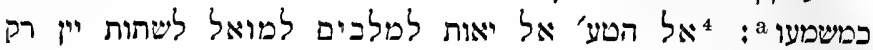

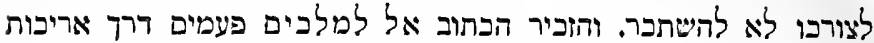

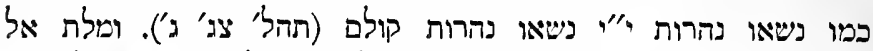

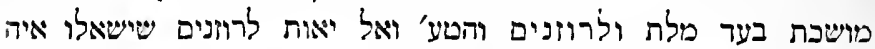

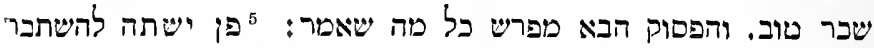

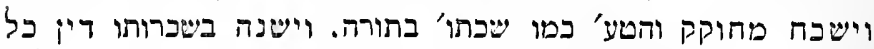

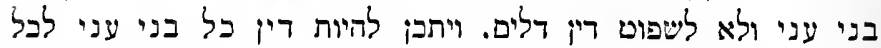

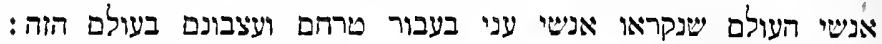

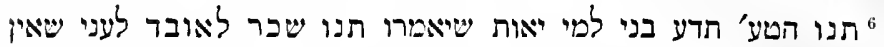

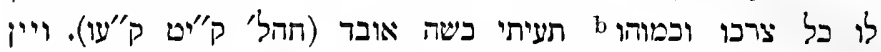

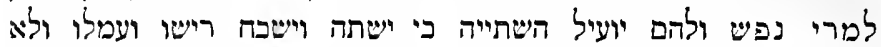

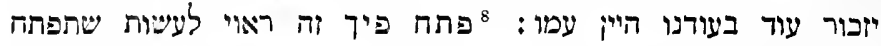

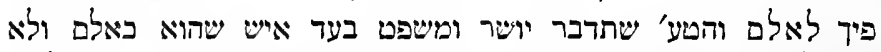

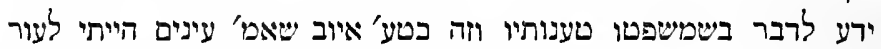

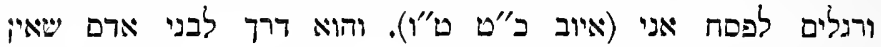

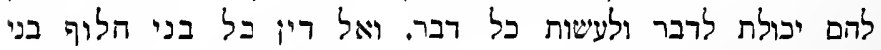

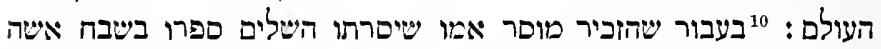

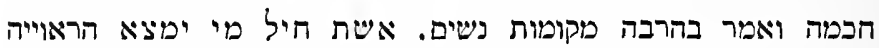

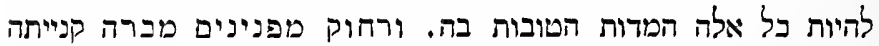

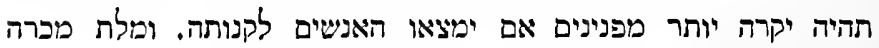

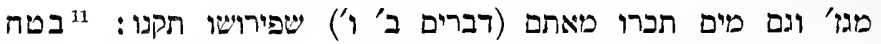

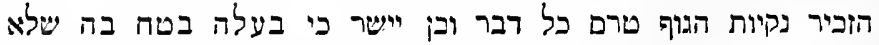

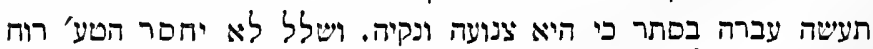

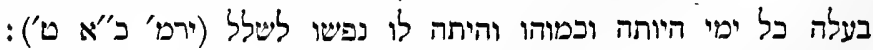
יבמלתהו הטע' עשתה [18 a

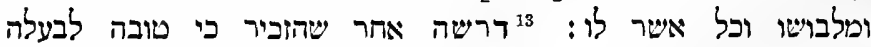

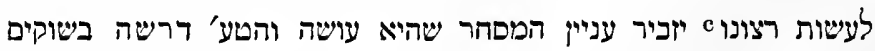

a ובספרו שפת יתר (מ"ה) כתב הראב"ע, אמר הגאון מלשון תרגום

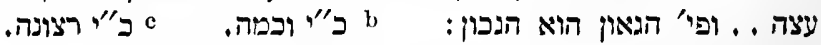


ביערות ובישדות והוא מהיר במרוצתו והנא המיש מותנים ותרגו' יריור

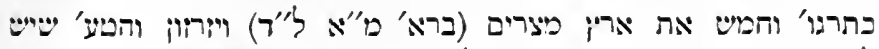

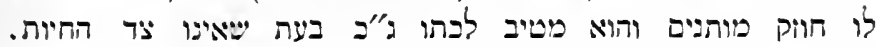

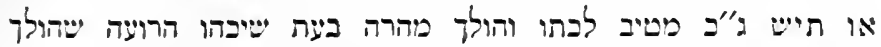

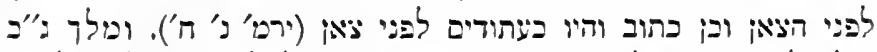

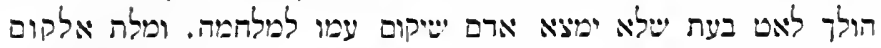

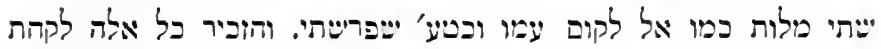

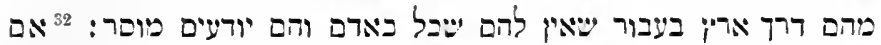

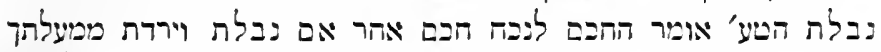

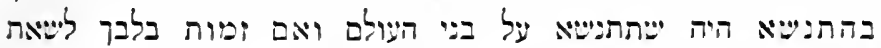

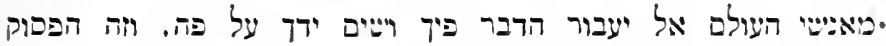

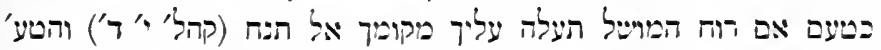

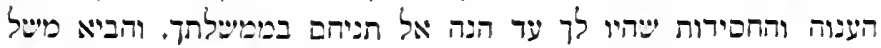

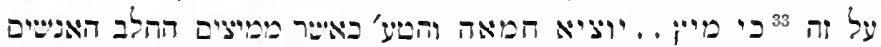

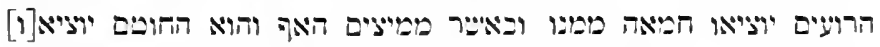

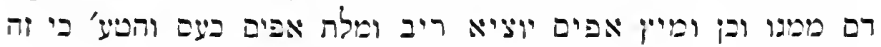

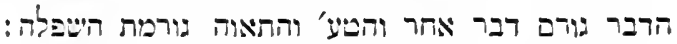
לא.

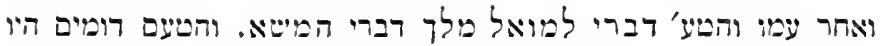

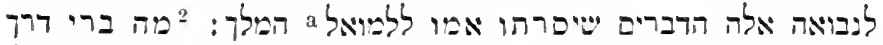

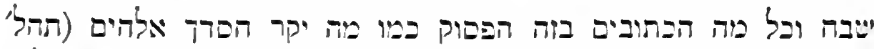

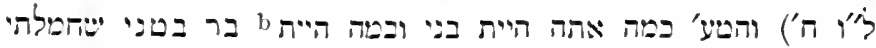

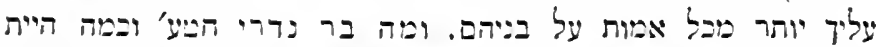

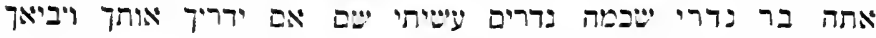
לדרך טובה:

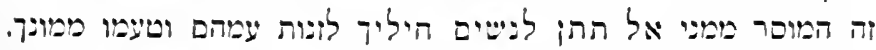

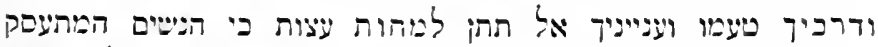

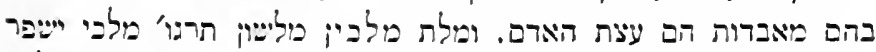

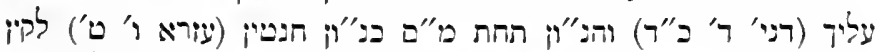

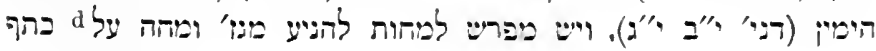

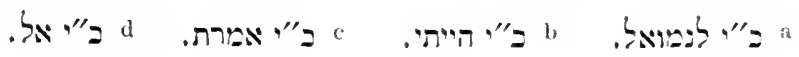




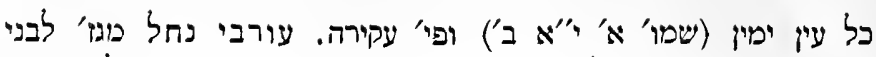

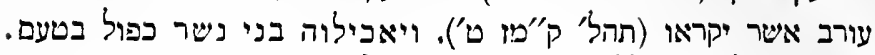

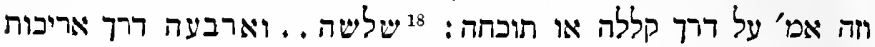

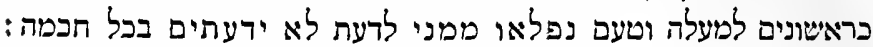

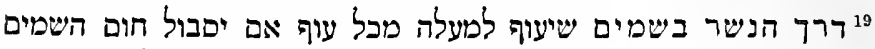

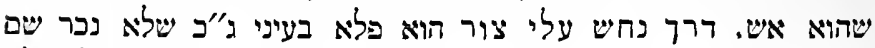

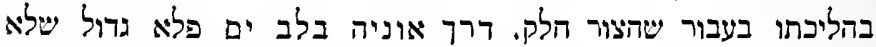

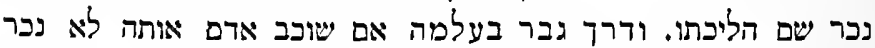

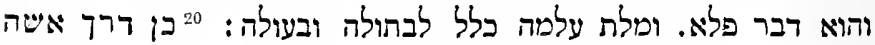

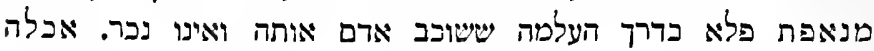

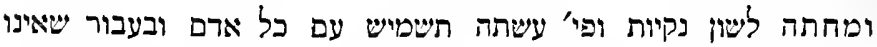

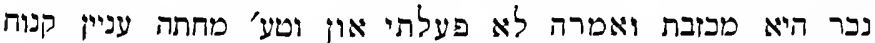

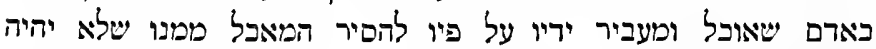

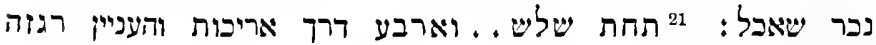

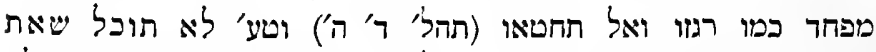

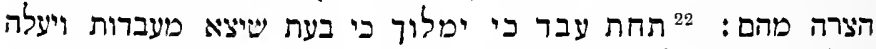

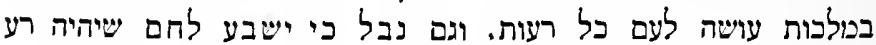
מעללים לעם:

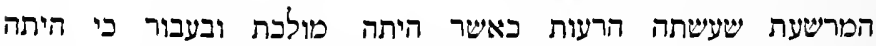

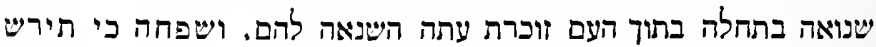

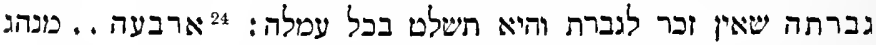

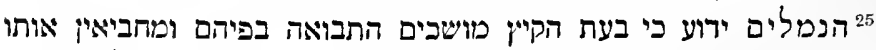

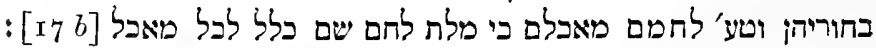

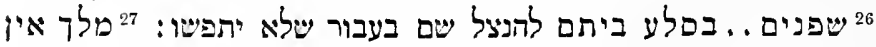

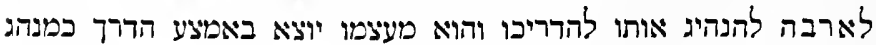

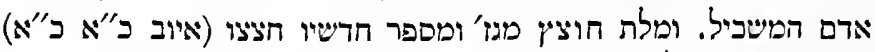

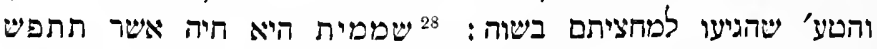

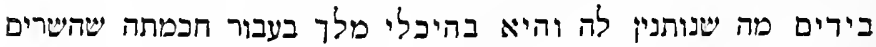

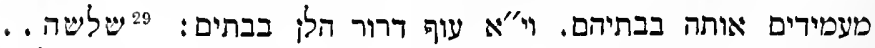

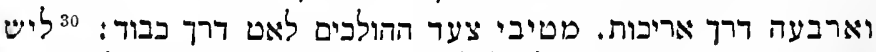

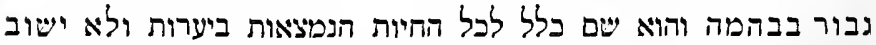

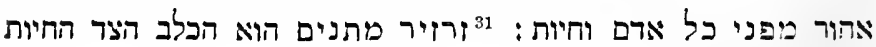




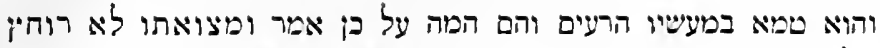
ישלא יטהר עצמו מעבירותיו:

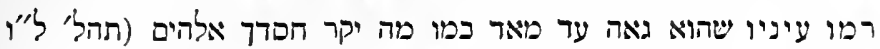

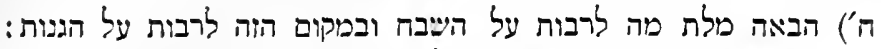

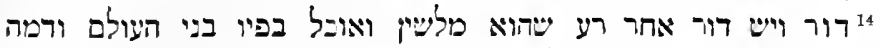

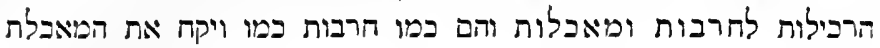

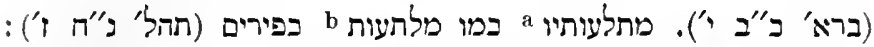

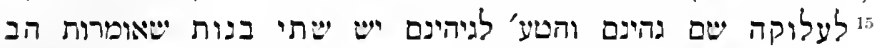

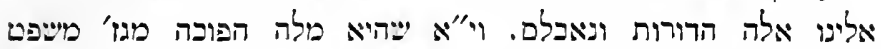

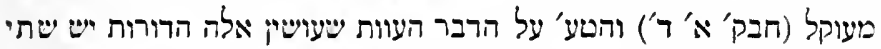

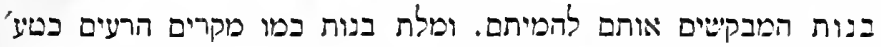

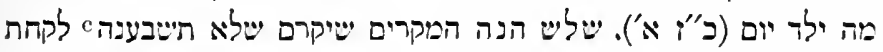

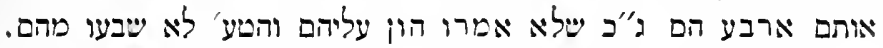

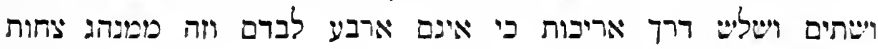

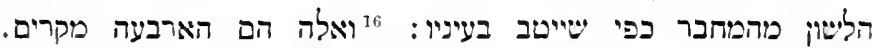

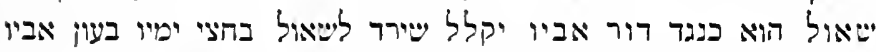

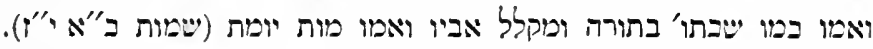

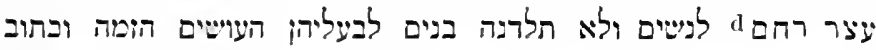

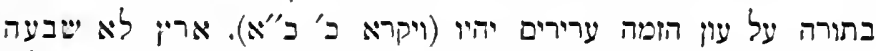

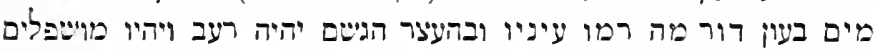

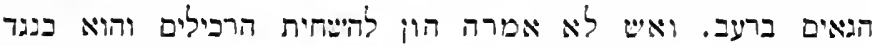

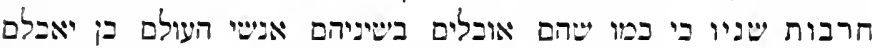

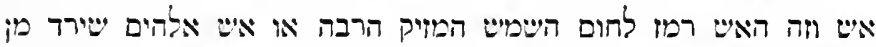

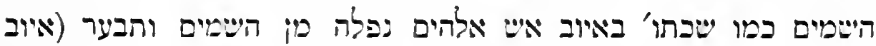

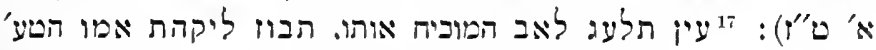

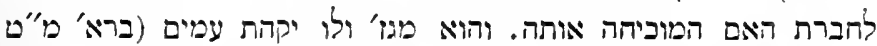

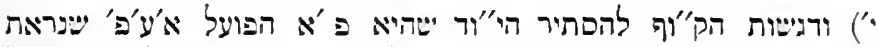

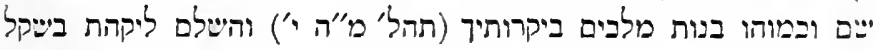

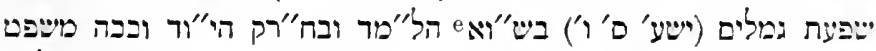

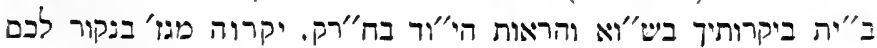

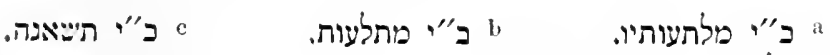

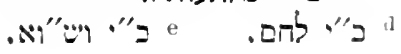




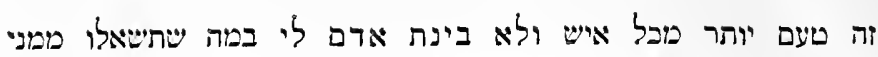

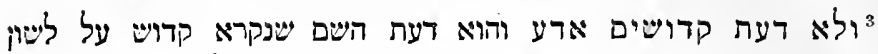

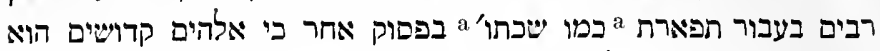

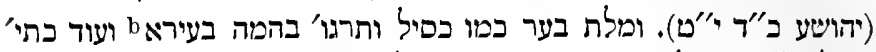

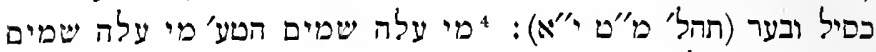

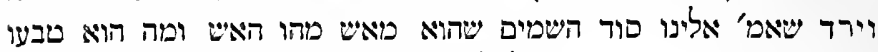

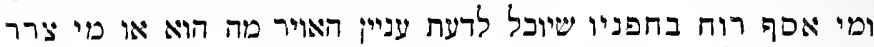

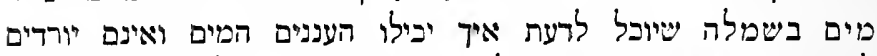

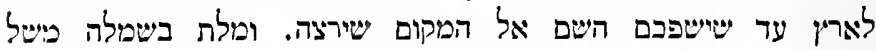

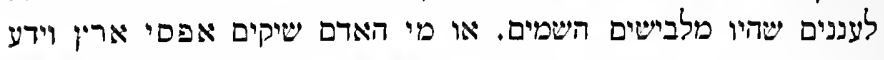

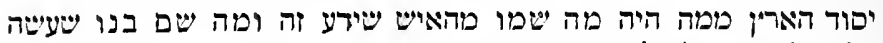

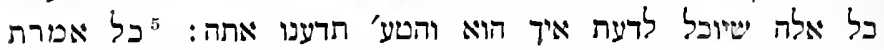

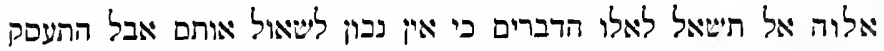

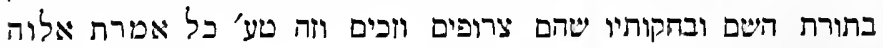
צרופה. והוא מגן [17 a

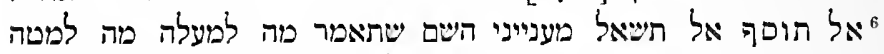

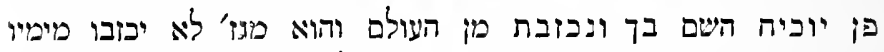

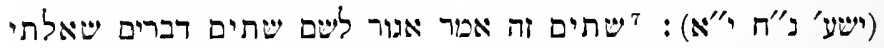

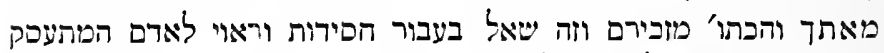

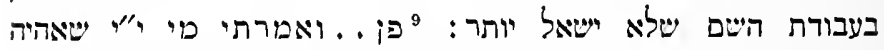

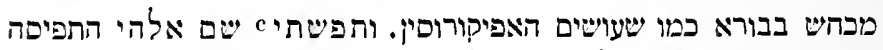

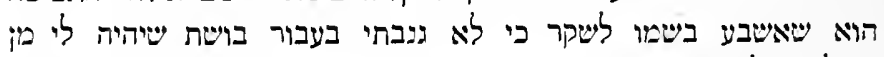

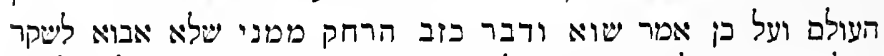

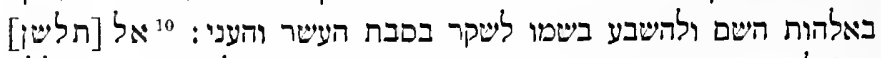

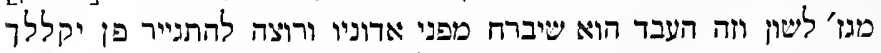

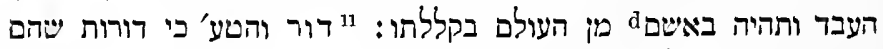

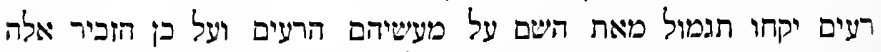

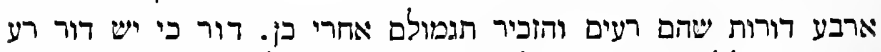

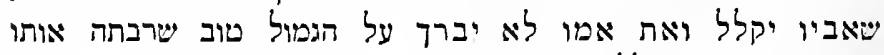

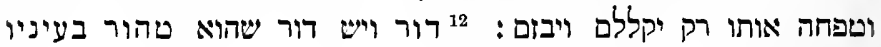

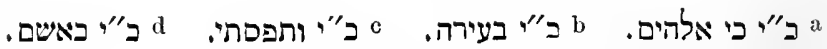




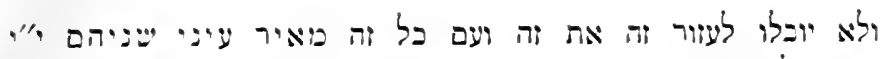
שיחת; להם בגנד פרנסתן:

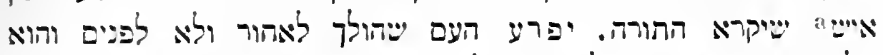

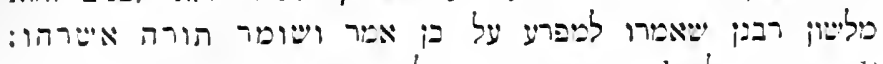

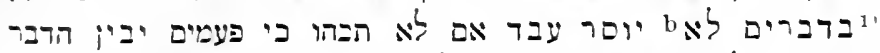

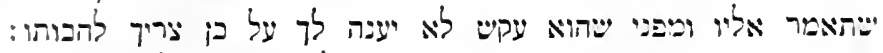

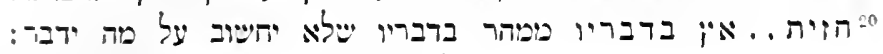

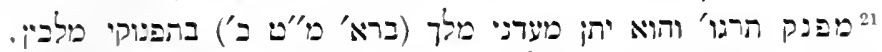

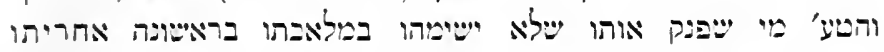

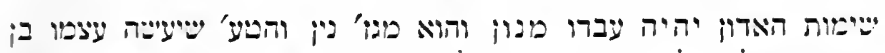

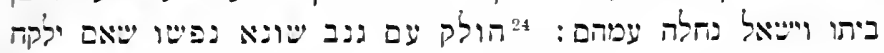

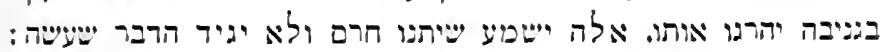

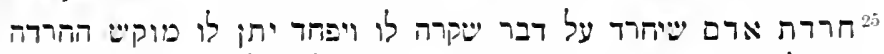

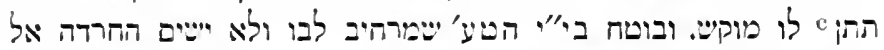

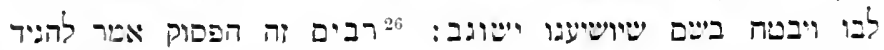

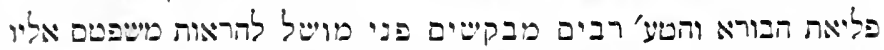

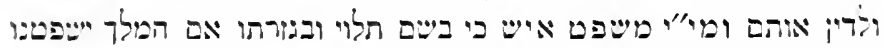

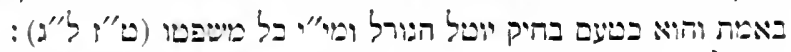

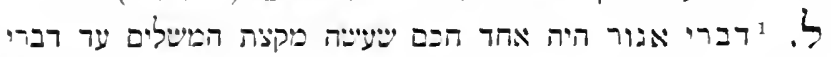

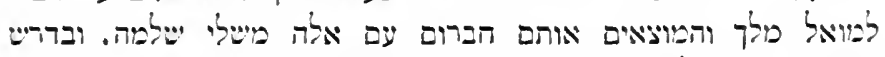

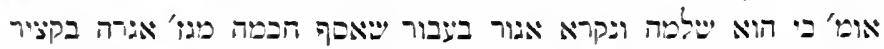

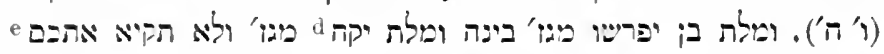

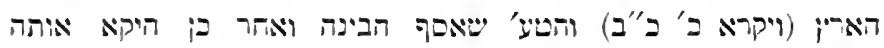

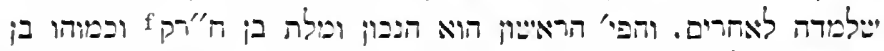

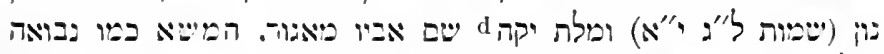

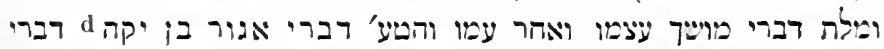

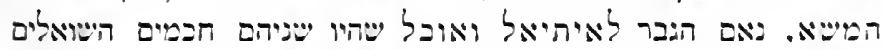

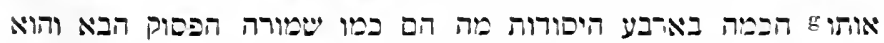

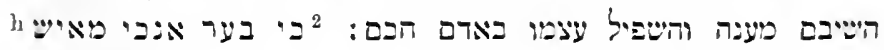

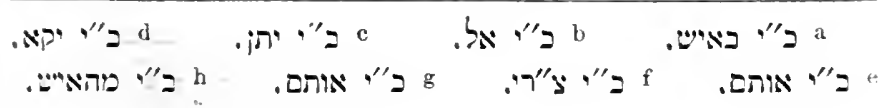


בי אבי ואמי הם וכל מה שהם טורחים בשבילי הם טורחים ואמר

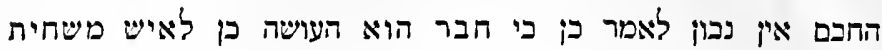

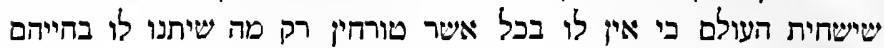

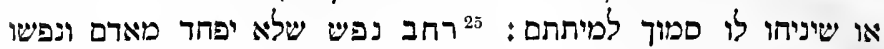

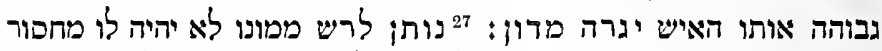

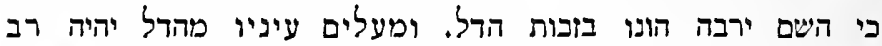
מארות שרבות חסרונות תבאנה לו [16 [16]

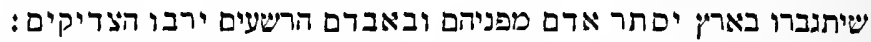

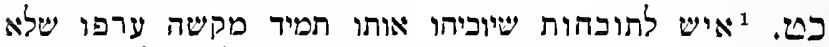

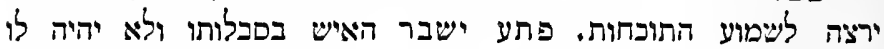

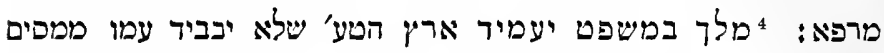

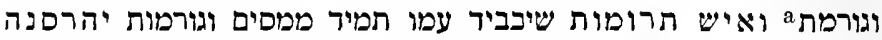

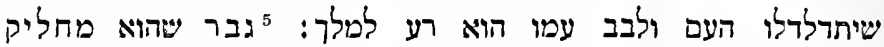

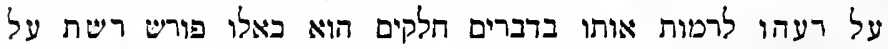

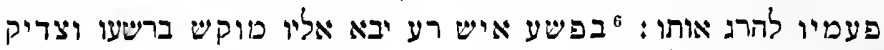

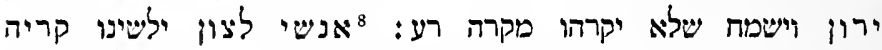

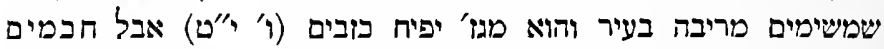

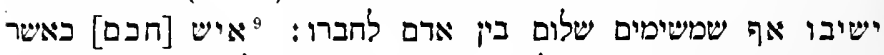

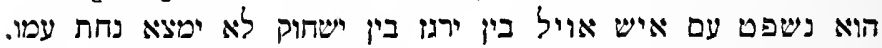
ובוה מגיר בי חברת אויל ודבריי קשה לחבם:

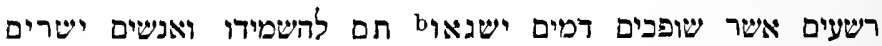

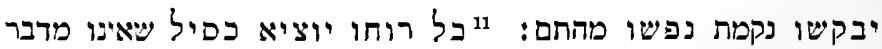

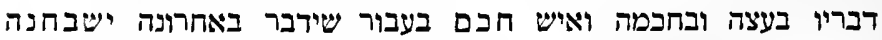

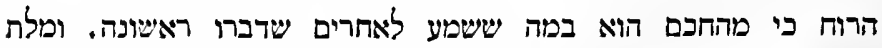

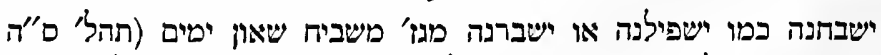

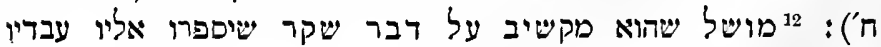

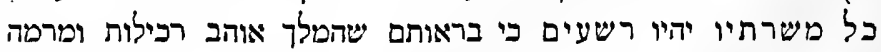

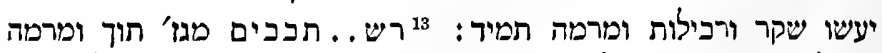

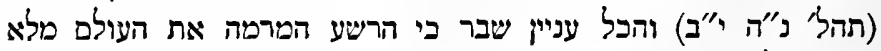

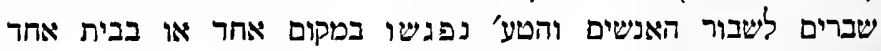




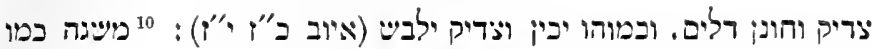

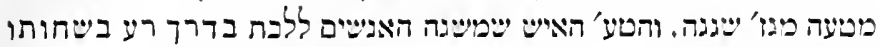

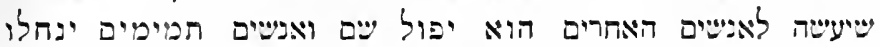
טוב:

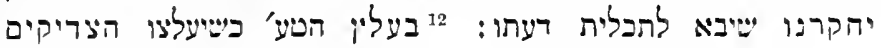

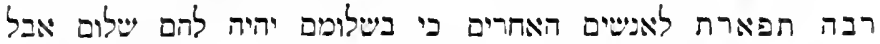

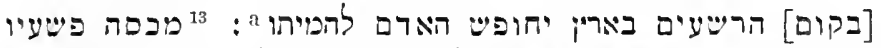

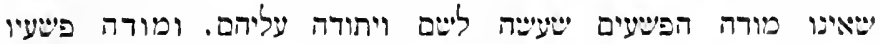

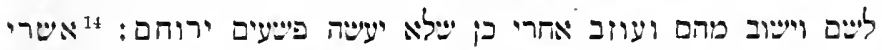

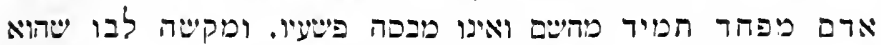

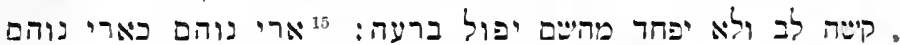

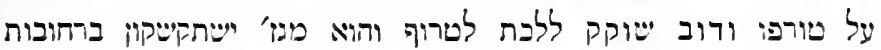

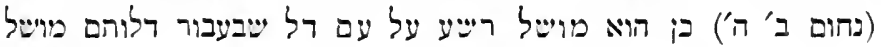
עליהם בחוקה ובפרך:

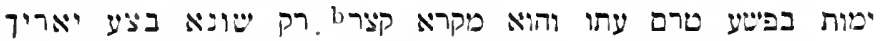

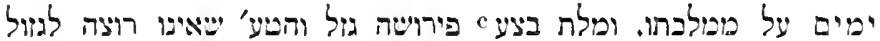

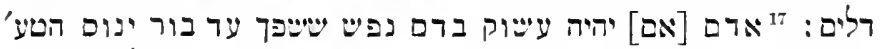

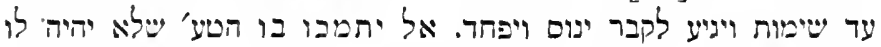

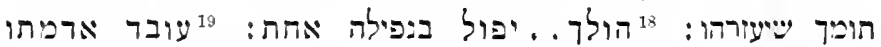

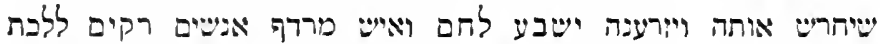
עמם ויתרפה ויתעצל בוה ישבע רייש:

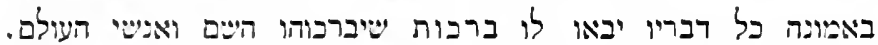

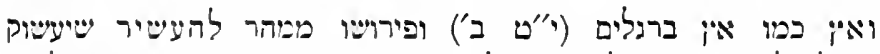

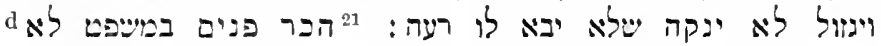

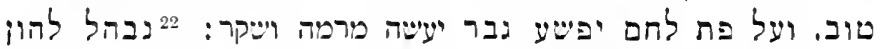

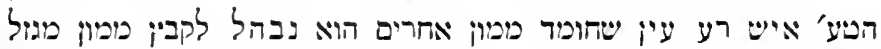

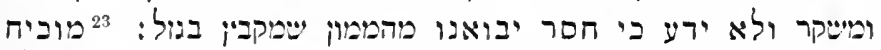

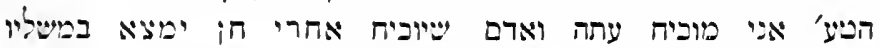

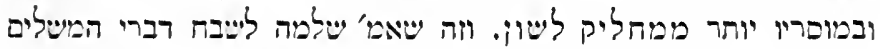

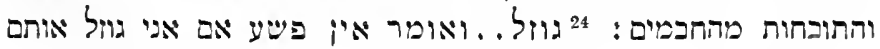

a כ"י, להמותו.

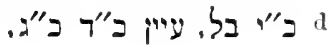




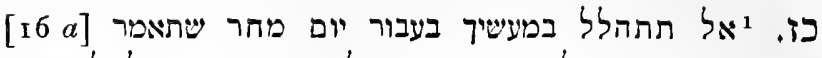

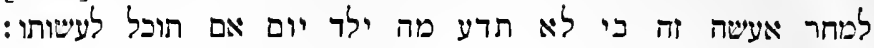

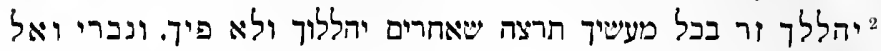

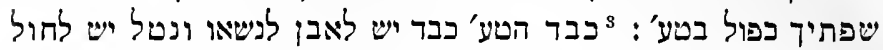
לנטלו ובעם אויל כבד משניהם לנים לנשוא:

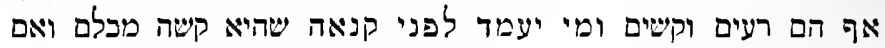

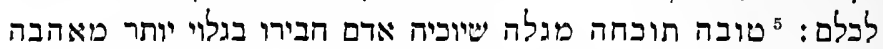

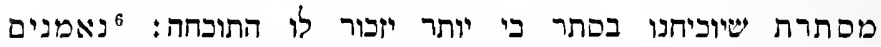
הטע' אם יפצע לד אוהבך להוביח אותך פי השונא אותך לאי יעיתה

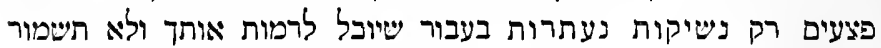

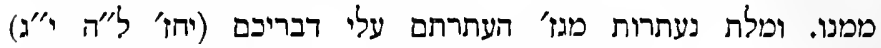

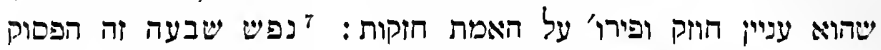

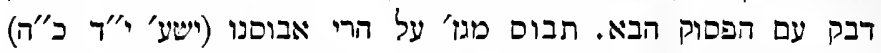

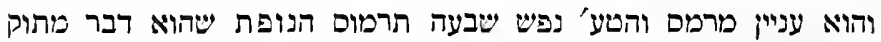

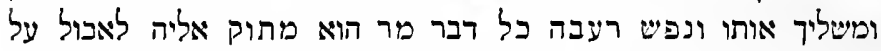

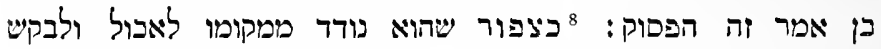

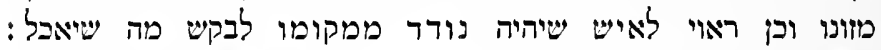

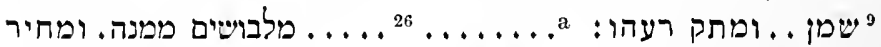

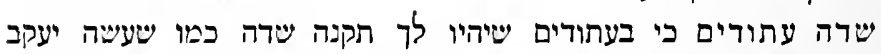

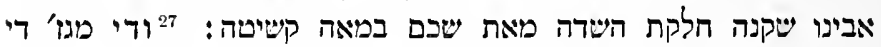

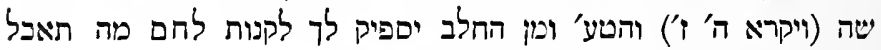

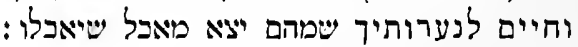

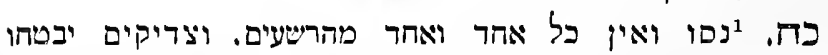

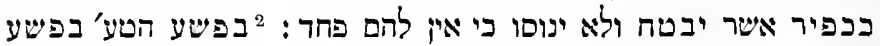

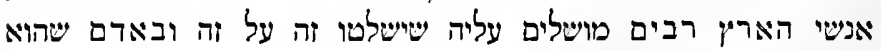

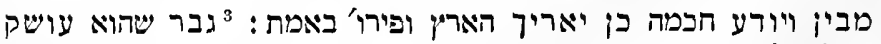

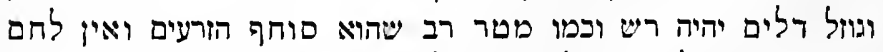

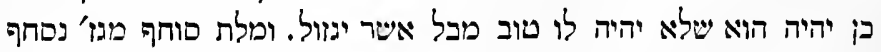

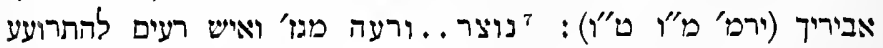
(י)"ח כ"ד): והטע' שהשים יסבב סבות שיבא כל הממון שקבין הרשע למי שהואי 
זרודה בכלי והוא מגו' חיל. ושובר כסילים שישימם לעבודתו ושוכר

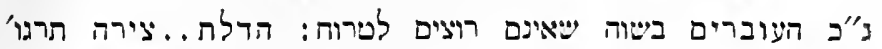

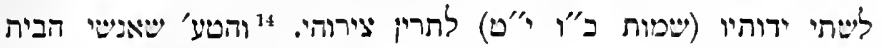

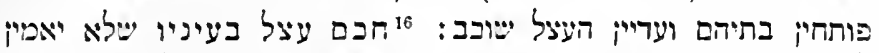

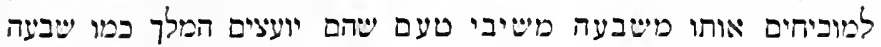

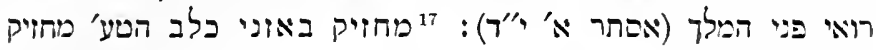

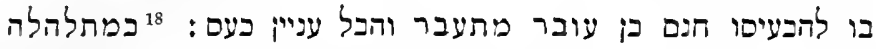

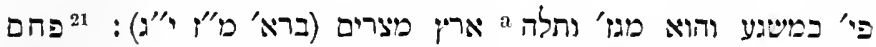

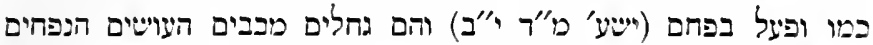

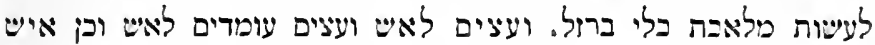

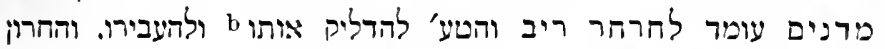

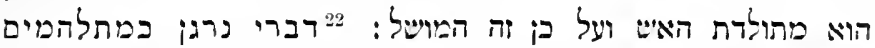

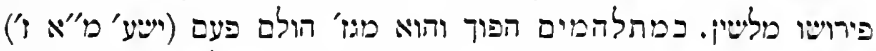

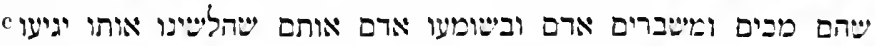

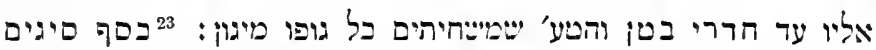

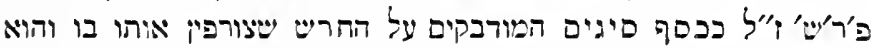

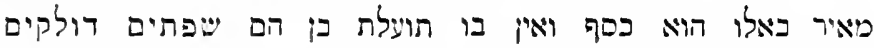

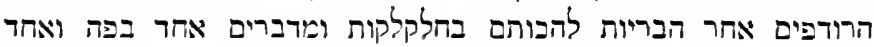

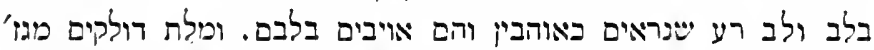
בי דלקת אהרי (ברא' ל"אי ל"ו"):

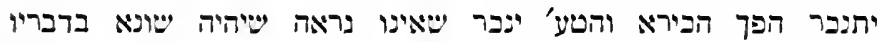

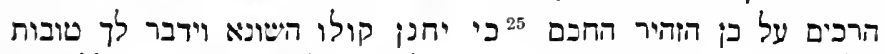

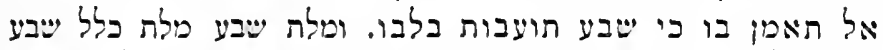

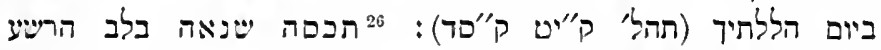

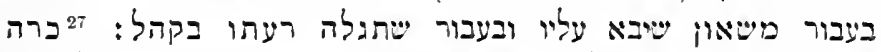

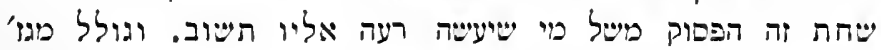

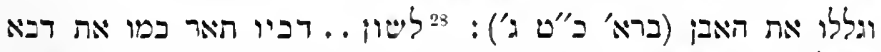

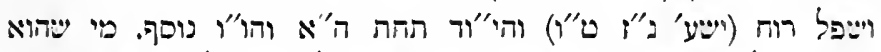

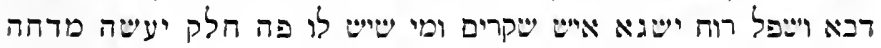
לאדם ברבריו השקרים:

a בכ"י עוד מלת את. בכ"י עוד מלת ולהב. כ"י יגיע. 


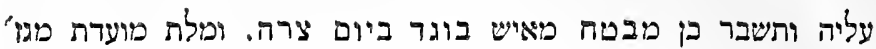

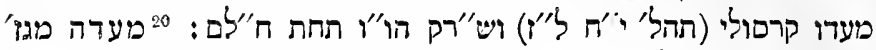

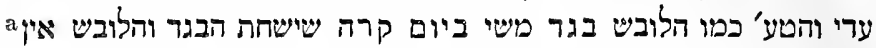

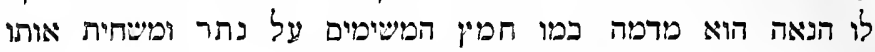

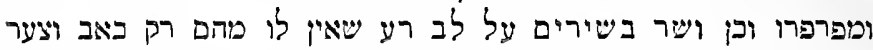

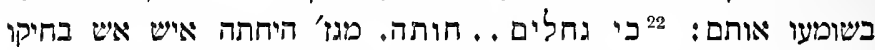

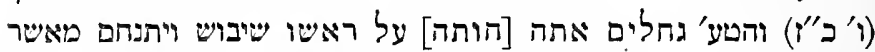

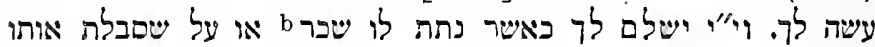

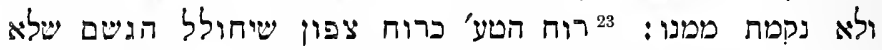

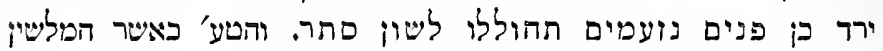

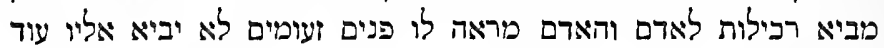

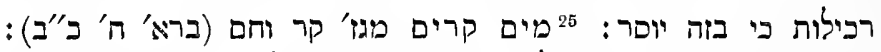

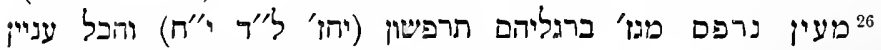

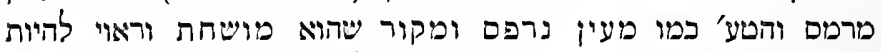

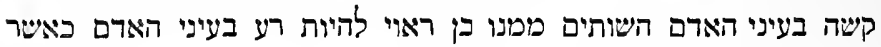

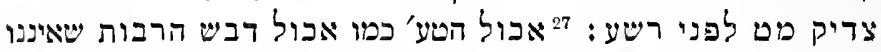

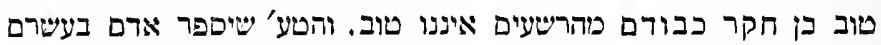

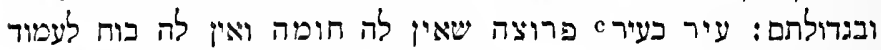

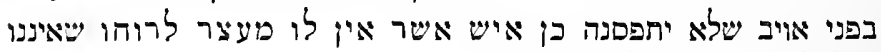

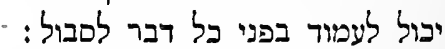
כו.

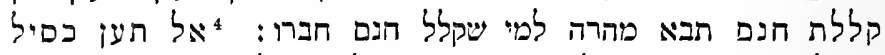

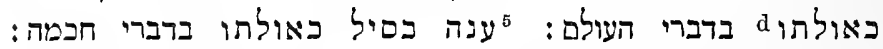

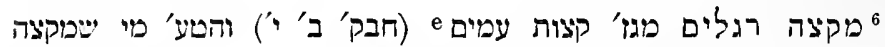

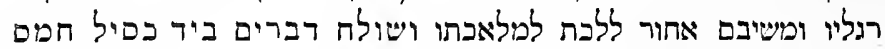

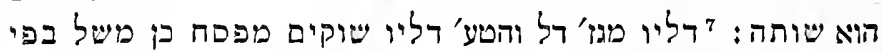

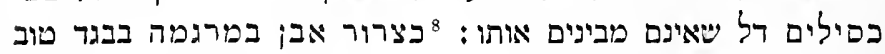

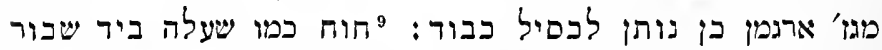

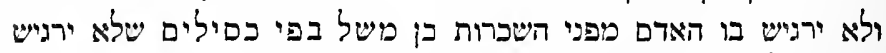

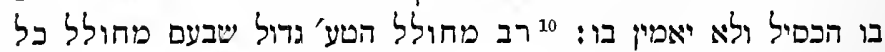

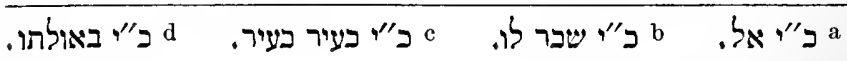
e ב"י האריץ. 


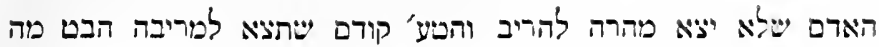

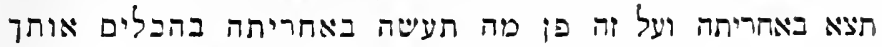

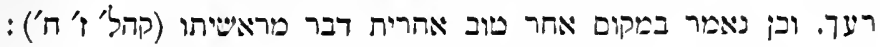

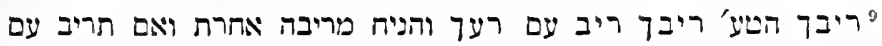

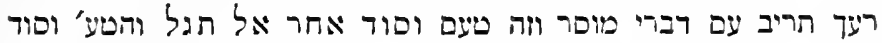

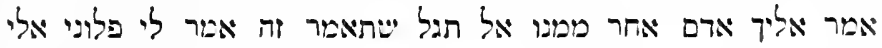

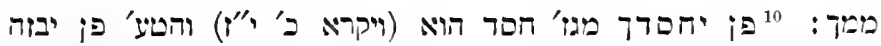

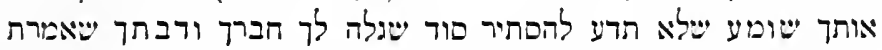

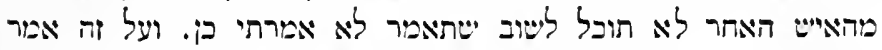

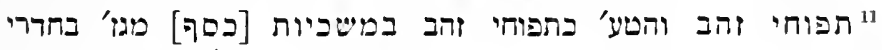

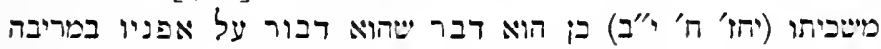

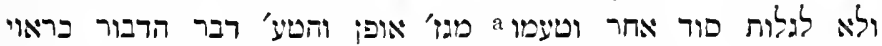

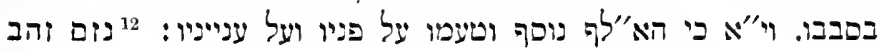

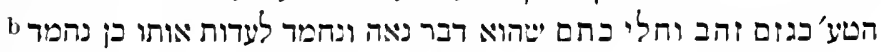

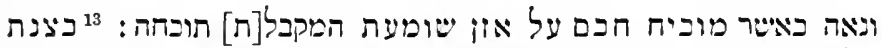

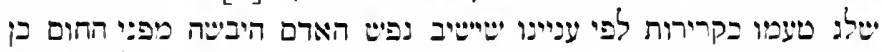

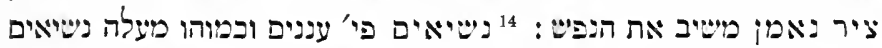

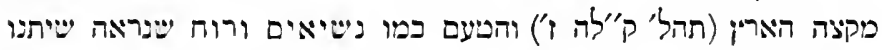

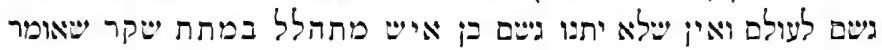
שיתן ולאי יתן:

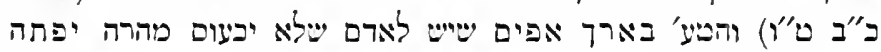
ת] [15b]

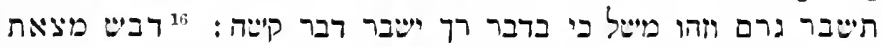

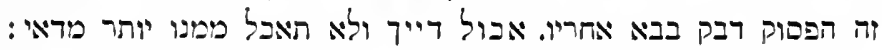

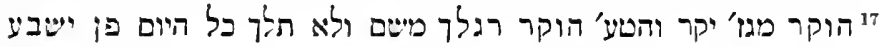

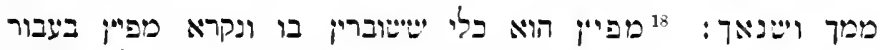

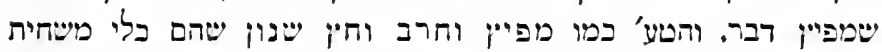

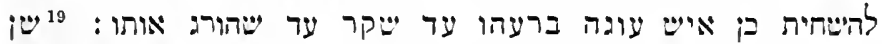

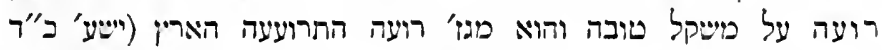

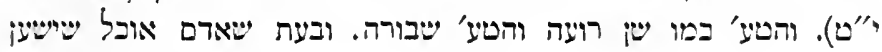

בכ"י עור על פניו ועל ענייניו. ב ב"י נאמר. 
ביתיך ממה שיצריך אליו: 28 אל תהי עד חגם פירושו עד שקר והטע'

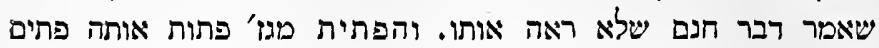

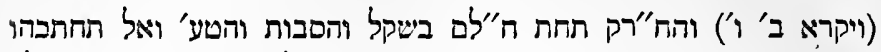

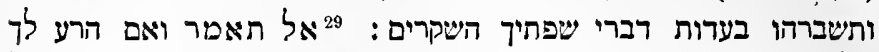

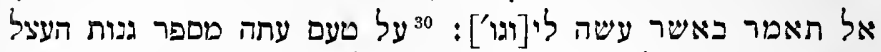

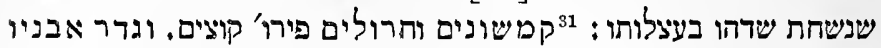

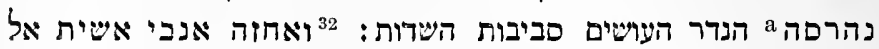

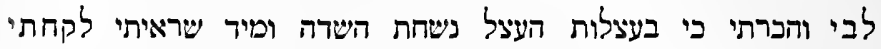

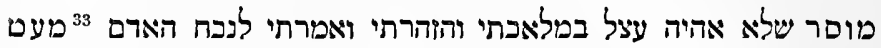

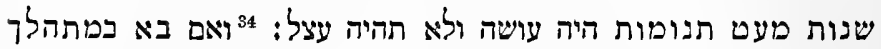

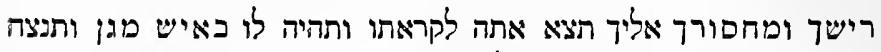

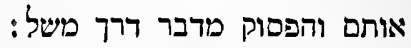

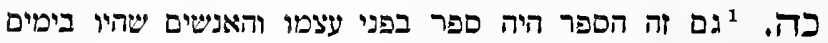

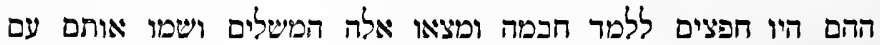

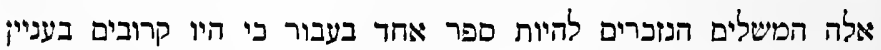

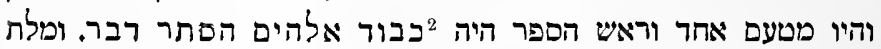

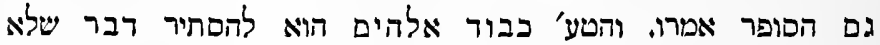

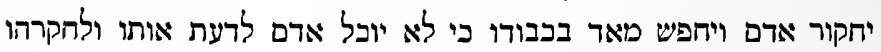

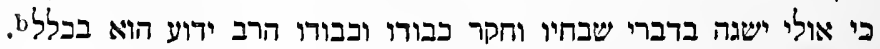

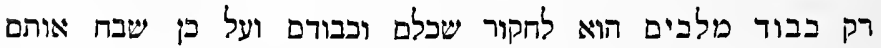

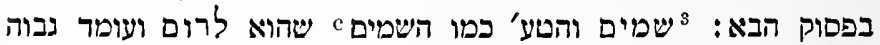

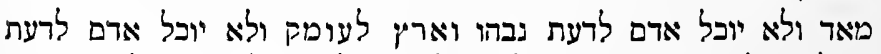

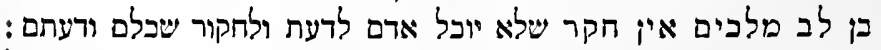

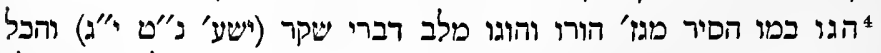

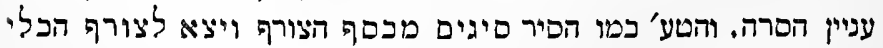

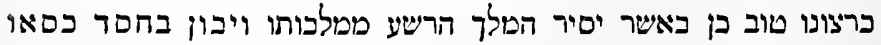

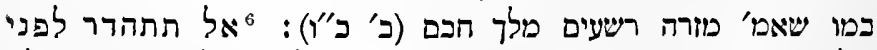

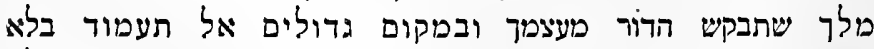

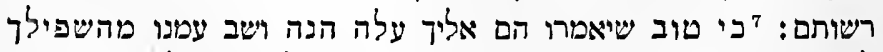

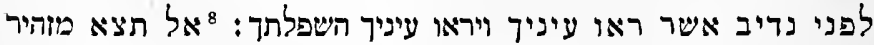

a כ"י גדר אבניו ונהרסה. b עיין שפת יתר ט"i. 
ק"םד) וכן רבים. ורשעים יכשלו ברעה תחת שיאין להם זכות שיוכלי

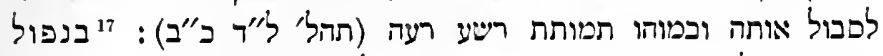

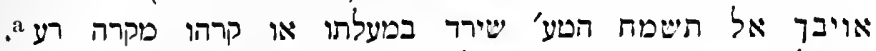

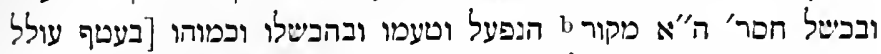

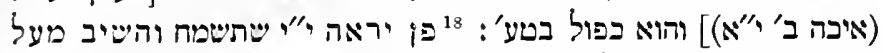

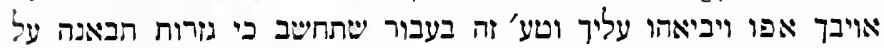

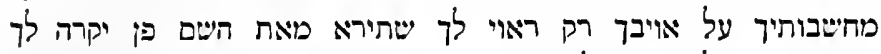

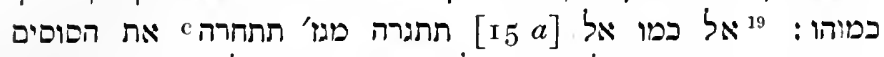

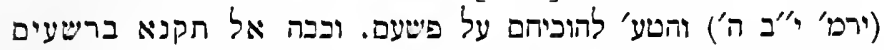

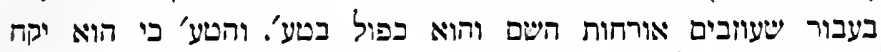

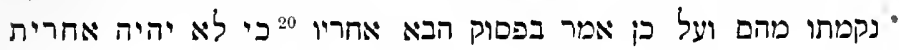

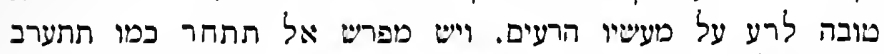

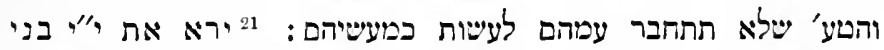

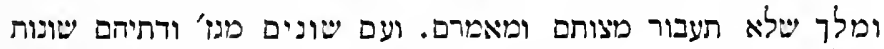

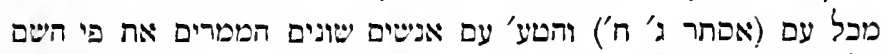

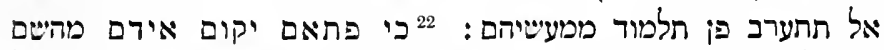

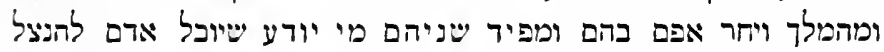

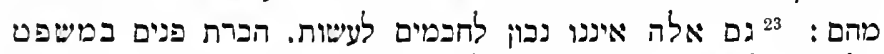

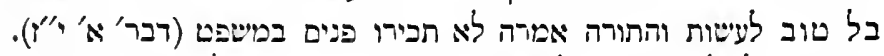

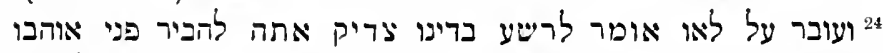

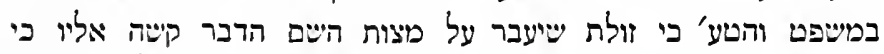

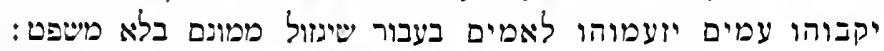

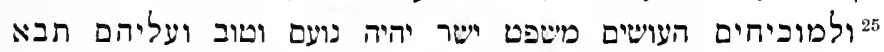
ברכת טוב הפך יקבוהו עמים:

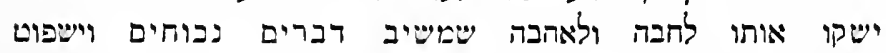

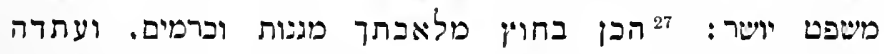

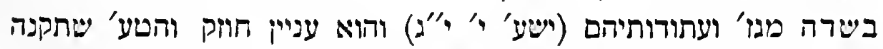

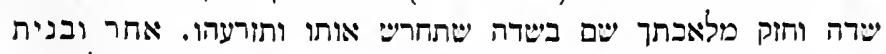

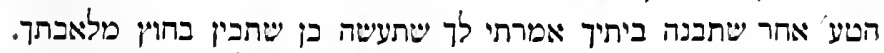

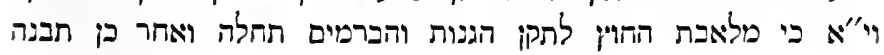

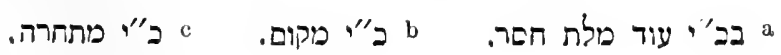




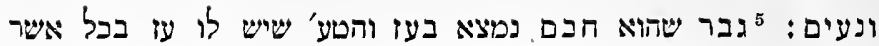

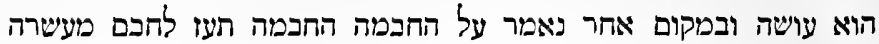

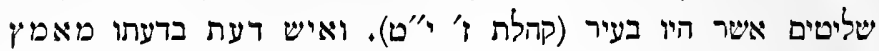
כח בכל ענייניו בי הדעת תספיק אליו בכל אשר הואי עיר עושה:

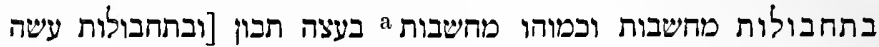

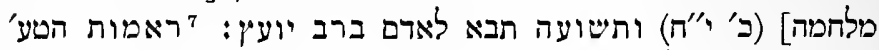

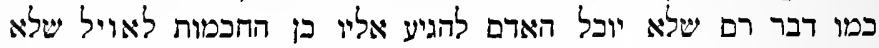

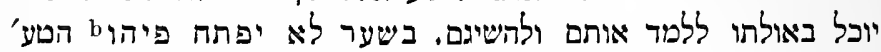

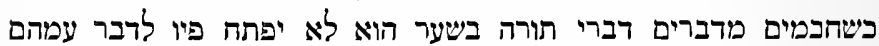
ויש לו בשת: ${ }^{8}$ מחשב להרע לאים לאחרים לו בעל מזמות יקראו בעבור

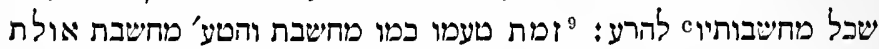
חטאת נחשבת והראוי להיות לאדם תועם כתבה שימאם אותו הוא הליץ.

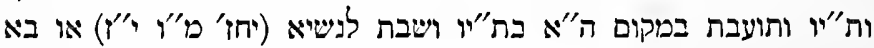

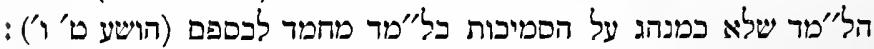

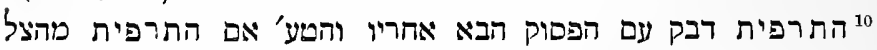
לקוחים למות ביום צרתם ומטים להרג אי אם תחשך להצילם כן ביוים

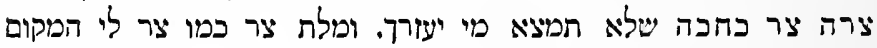

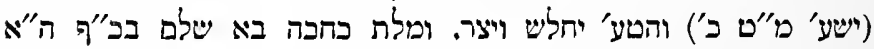

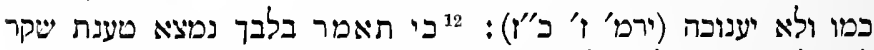

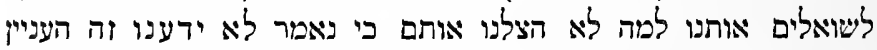

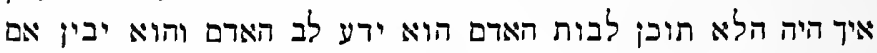

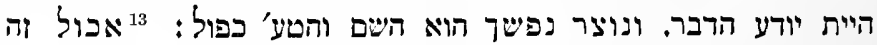

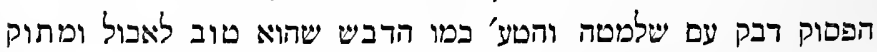

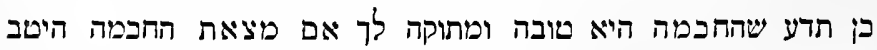

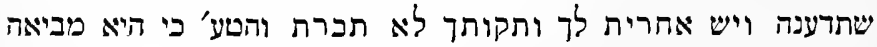

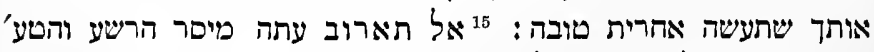
אתה רשע אל תארוב לנוה צדיק להשחיתו. תשרד מגו' שיורד.

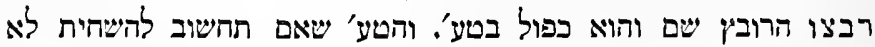

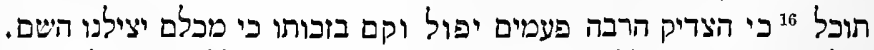
ומלת שבע הוא כלל חשבון גרול כמו שבע ביום הללתיך (תהל' ק"יט 


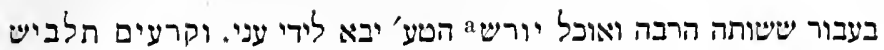
נומה כאשר רודף האדם אחריה ויישן בי בעבורה יתעצל וילביש מלבושים

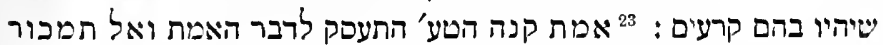

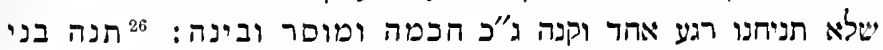

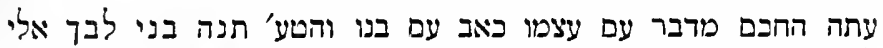

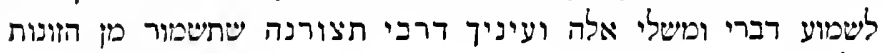

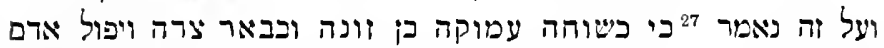
ישם וימות כן הנבריה ממיתה:

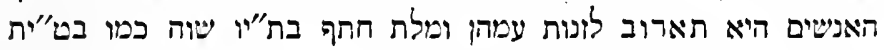

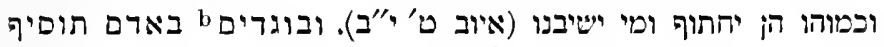
• בנוניה כי היא תשים אותם לשוב בוגדים באמריה ההלקים:

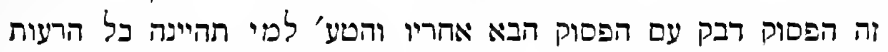

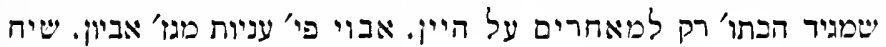

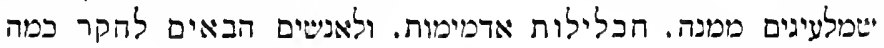

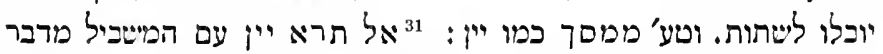

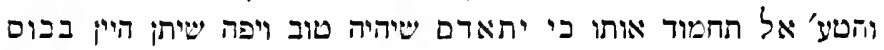
עינו מראיתו והטע' שיהיה לו מראית טוב בכוס: בנחש ישכהו. יפריש תרגומו [של] מלמד הבקר (שיפט' ג' ל"אום) פרשאי

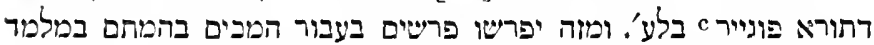

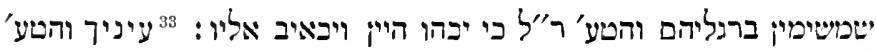

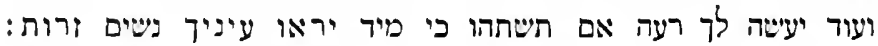

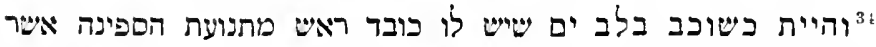

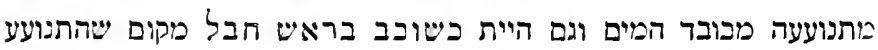

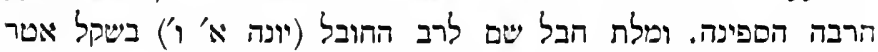

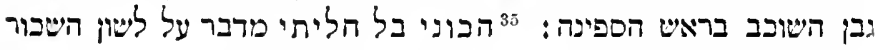

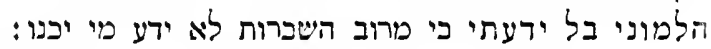

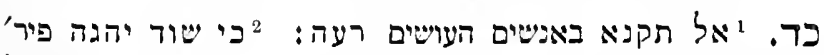

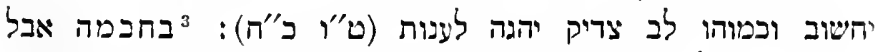

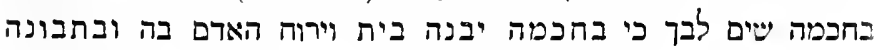
יתבונן הבית: "ובדעת שיהיה לארם חדרים ימלאו כל כל הון יקר
c Puregier.
בכ"י ובוגד.
a כ"י אורש. 
תבין לאבול את אשר לפניך ולא תשא עיניך במאכל המושל: 2 ושמת

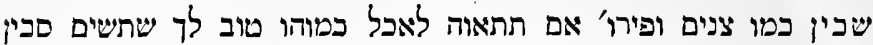

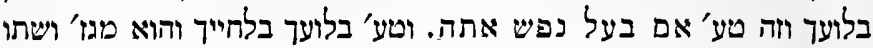

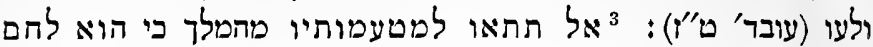

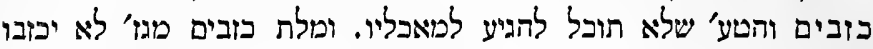

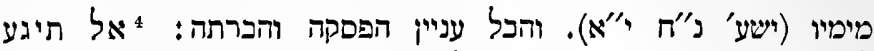

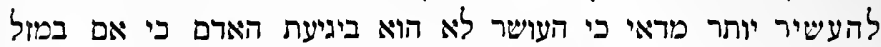

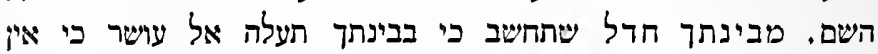

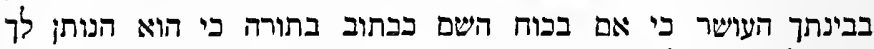

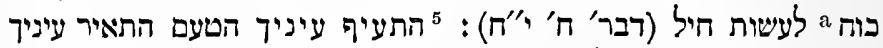

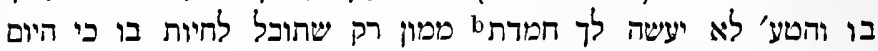

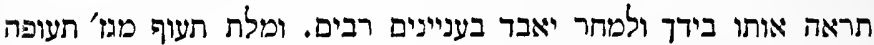

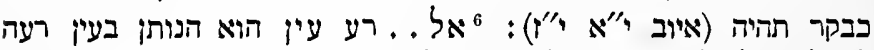

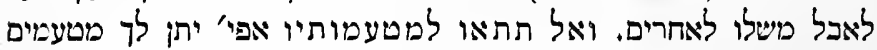

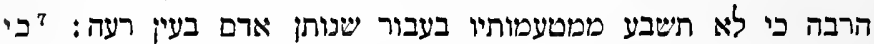

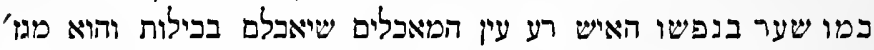

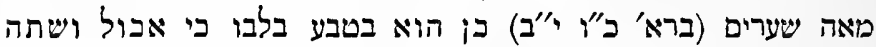

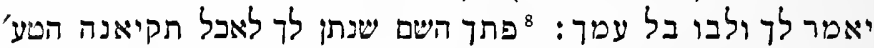

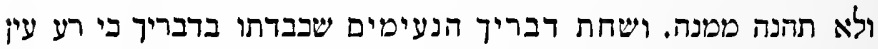

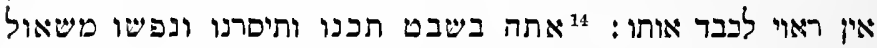

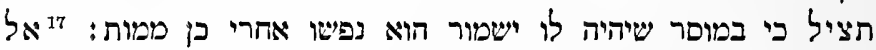

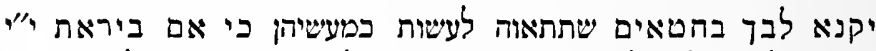

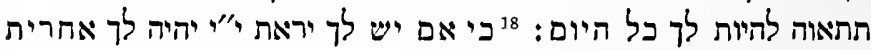

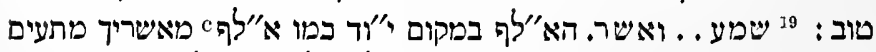

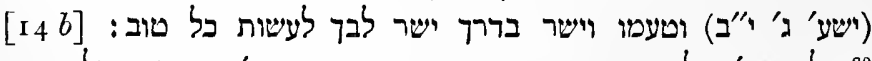
(20 אל הטע' אל תהי בחברת סובאי יין והוא מגוא' סבאך מהול במים

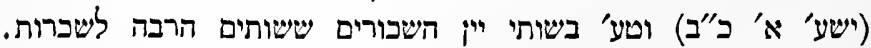

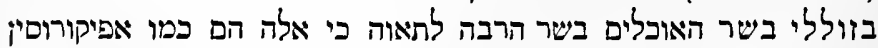

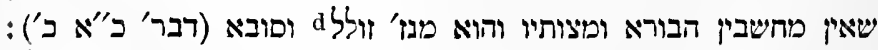

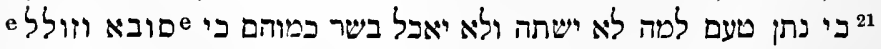

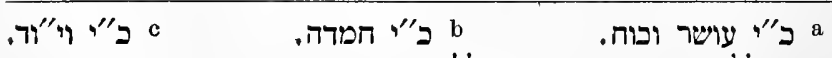

ב ב"י סוללי. 


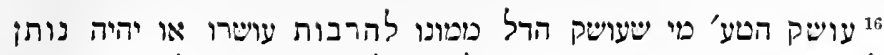

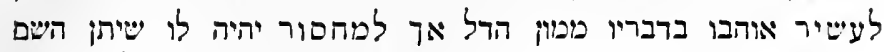
מחסורו בעושרו:

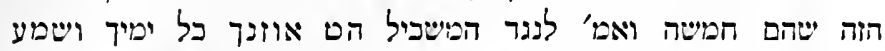

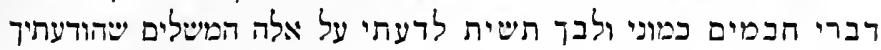

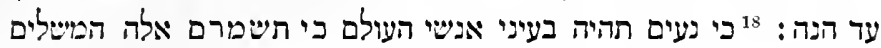

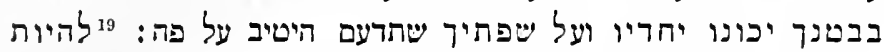

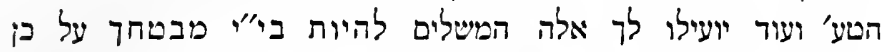

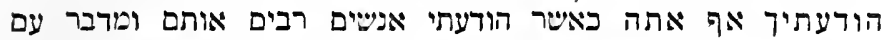

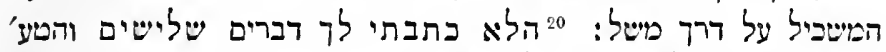

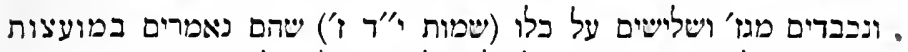

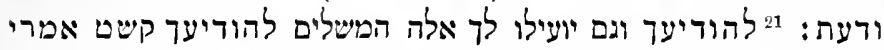

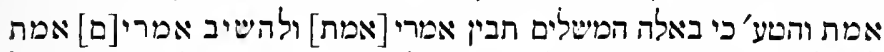

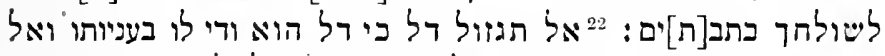

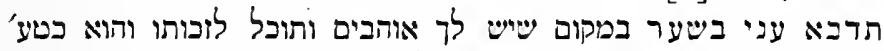

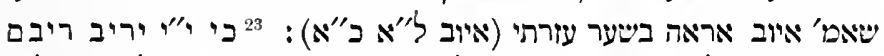

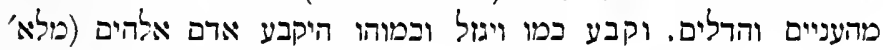

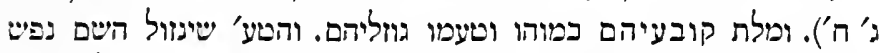

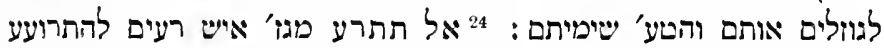

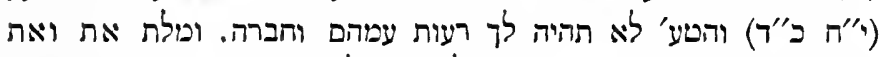
במו ועם ובמוהו רבים:

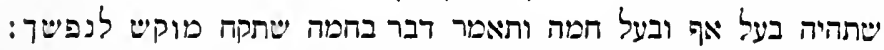

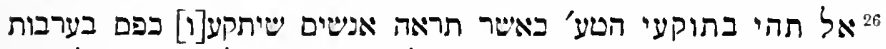

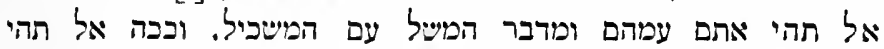

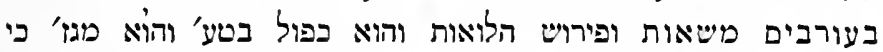

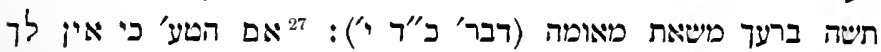

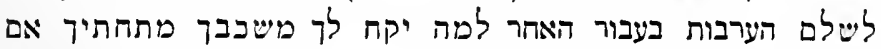
לא ימצא דבר אחר בער בעיתך:

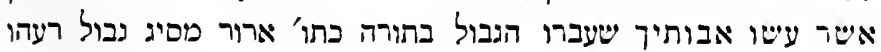
(דבר'ב"ן י"ו"):

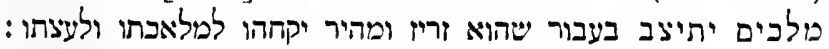

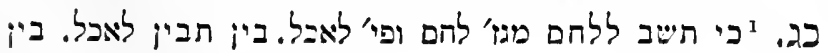


4עקב טעמו בעבור וכמוהו עקב שוחד (ישע' ה' כ"ג) והטע' בעבור

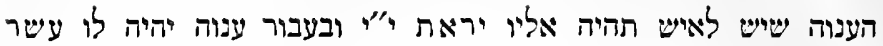

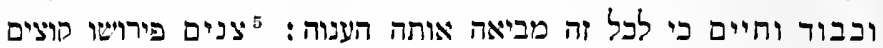

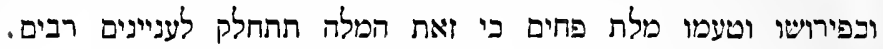

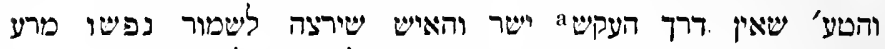

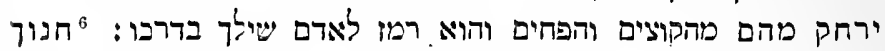

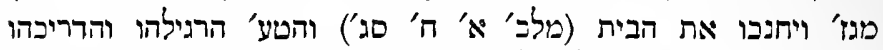

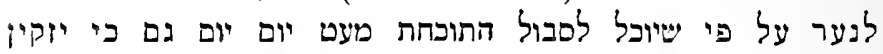

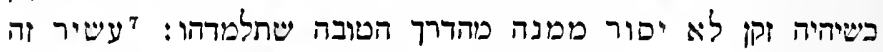

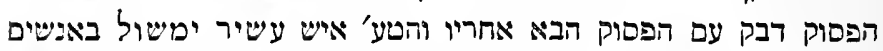

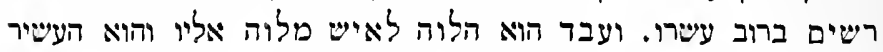

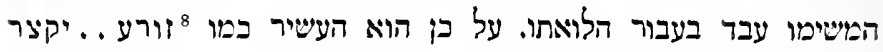

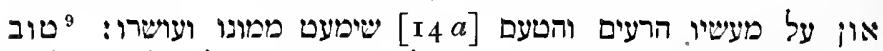

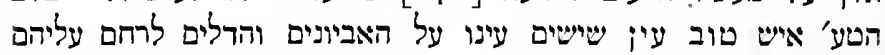

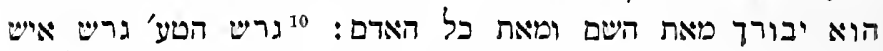

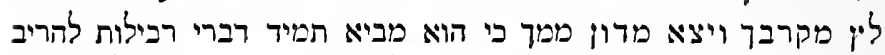

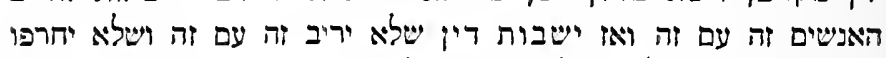

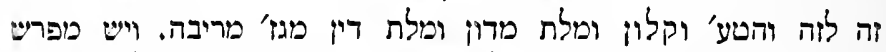

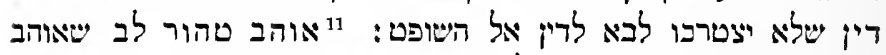

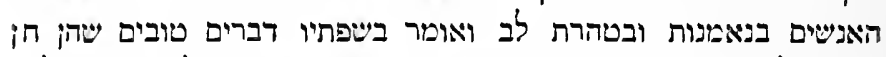

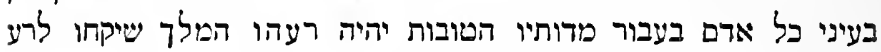

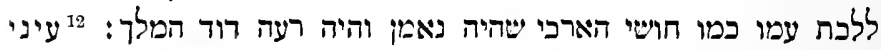

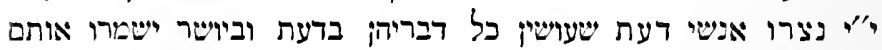

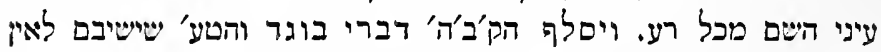

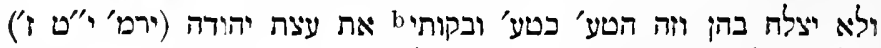

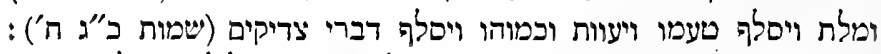

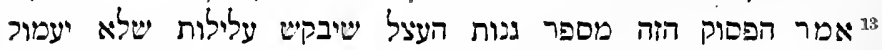

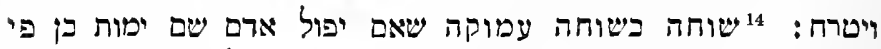

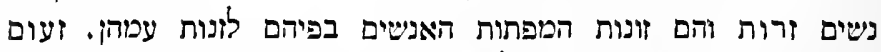

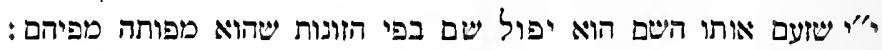

$$
\text { כ כ"י ובקוותי. }
$$$$
\text { a כ"י טע' העקר. }
$$ 


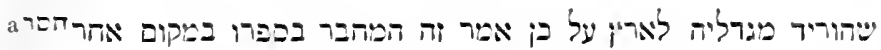

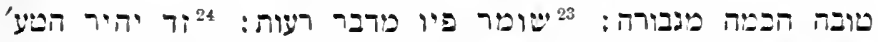

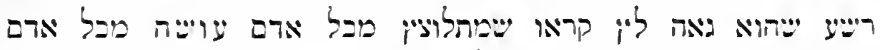

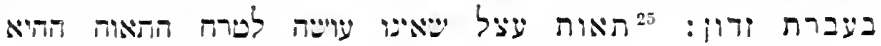

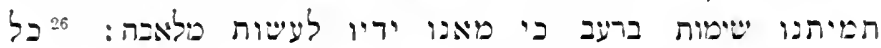

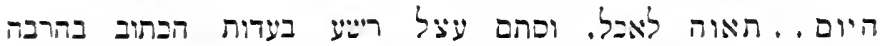

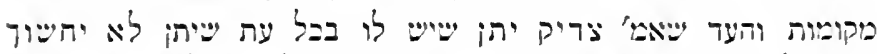

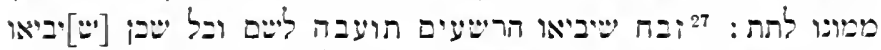

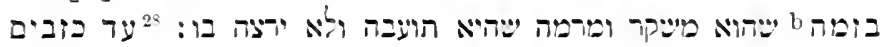

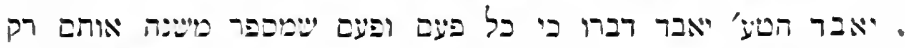

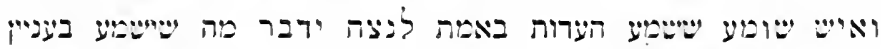

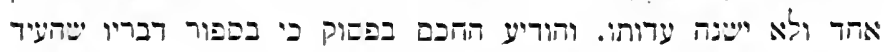

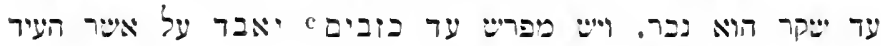

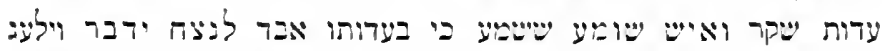

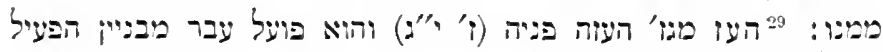

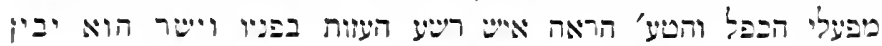

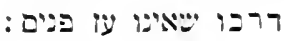

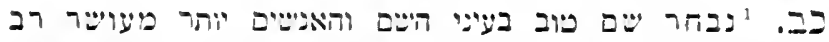

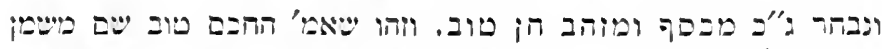

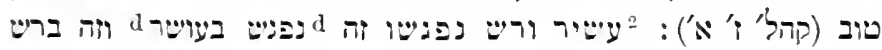

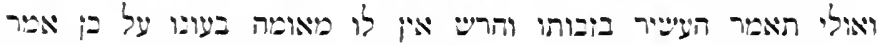

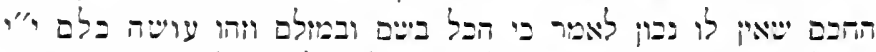

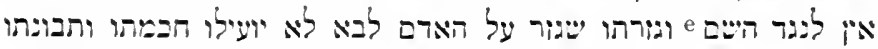

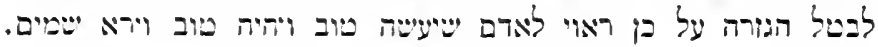

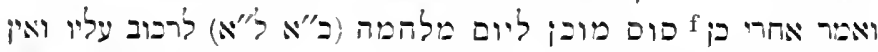

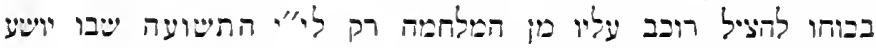

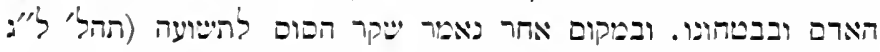
"ו"):

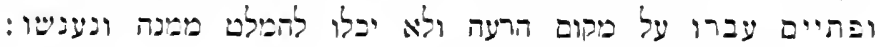

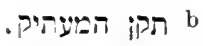

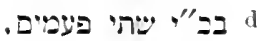

a

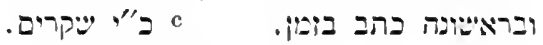
כ ב בה:סתקה. . ה" 


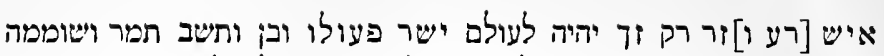

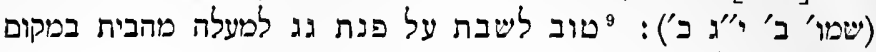

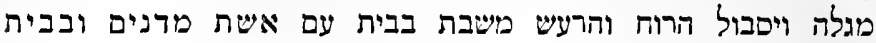

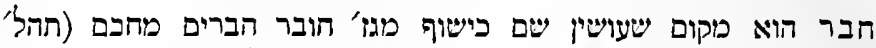

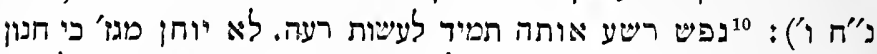

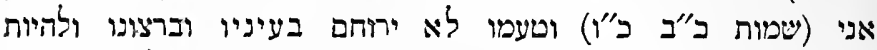

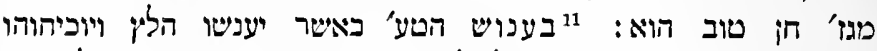
יחכם פתי מעצמו ובהשכיל לחכם אדם אדם ברברי מוסר מבלי ענש

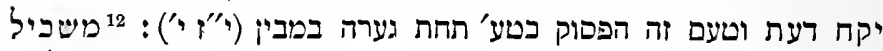

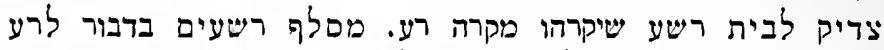

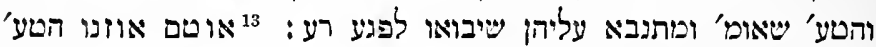

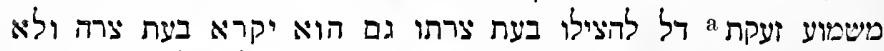

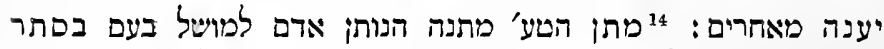

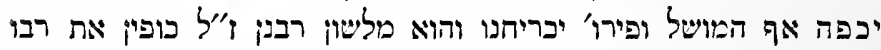

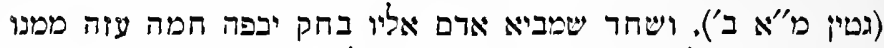

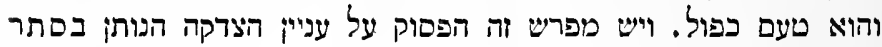

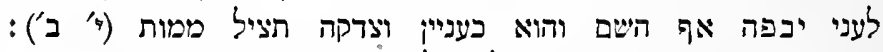

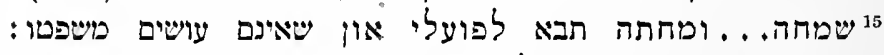

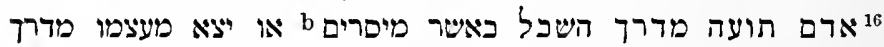

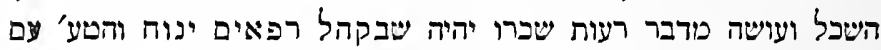

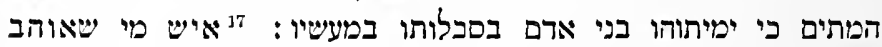

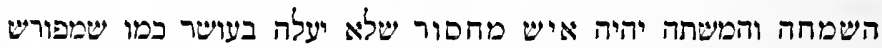

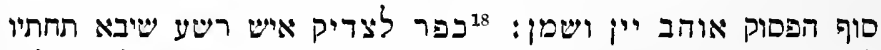

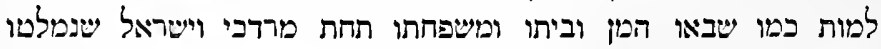

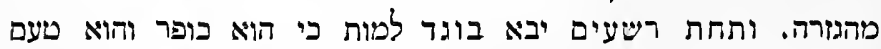

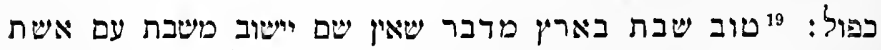

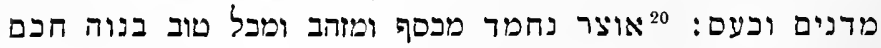

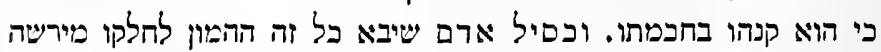

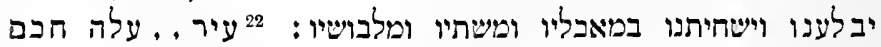

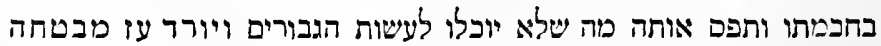




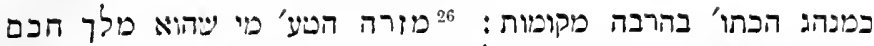

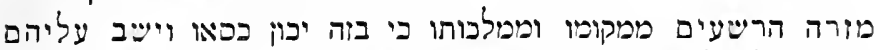

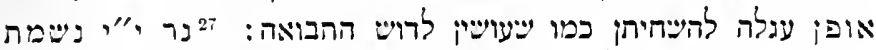

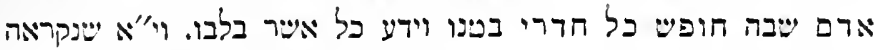

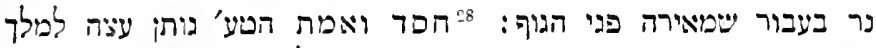

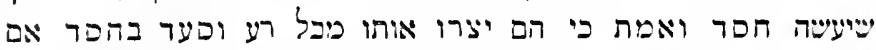

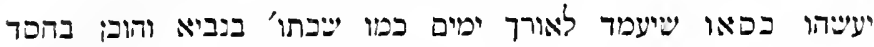

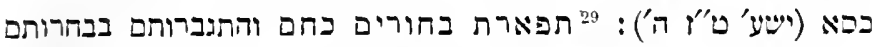

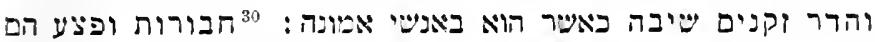

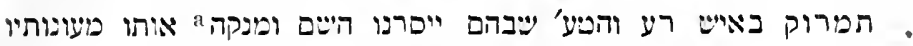

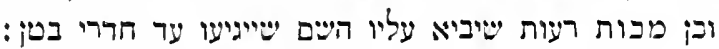

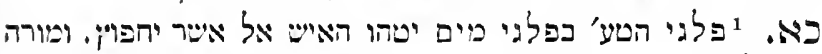

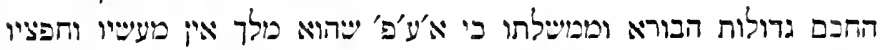

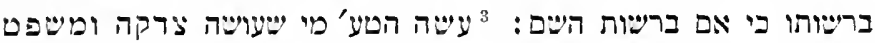

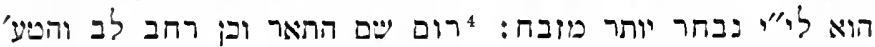

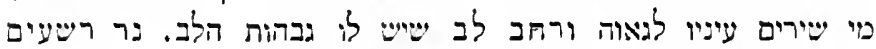

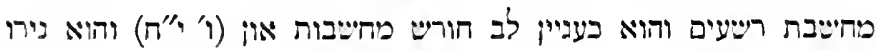

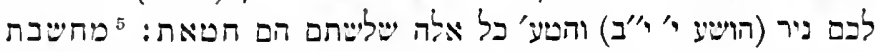

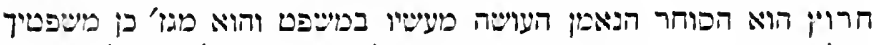

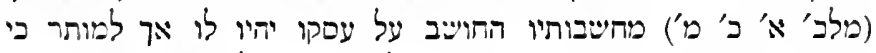

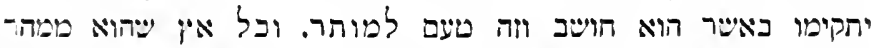
במרמה להעשיר יהיו מחשבותיו [13

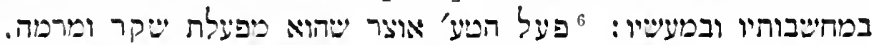

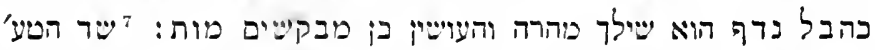

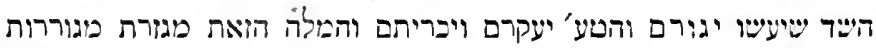

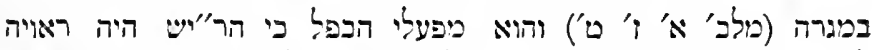

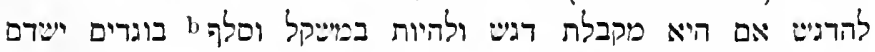

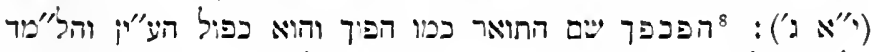

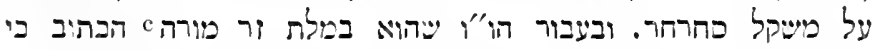

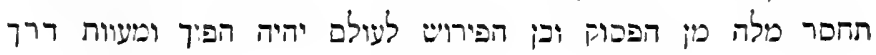




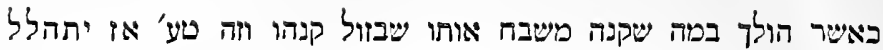

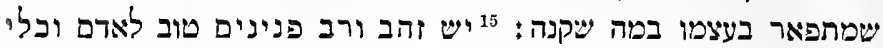

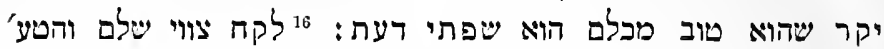

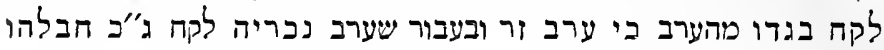

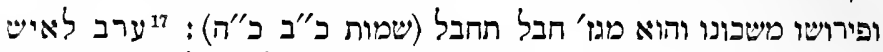

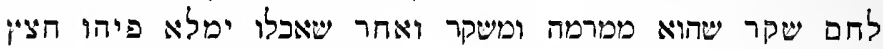

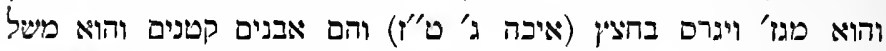

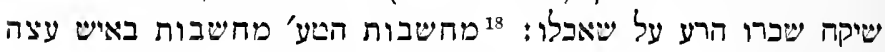

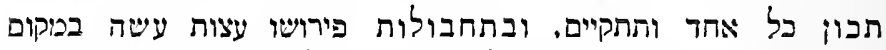

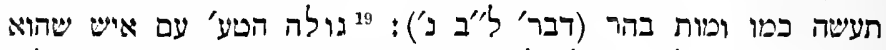

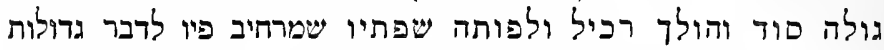

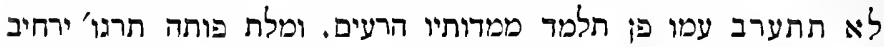

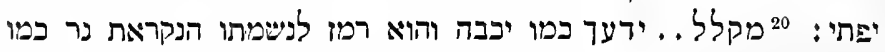

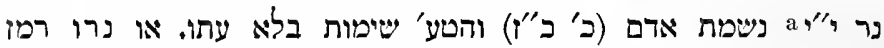

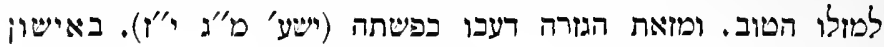

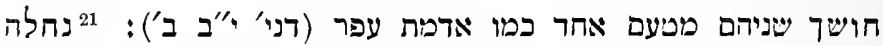

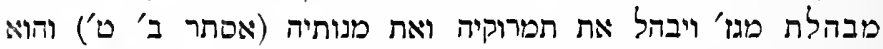

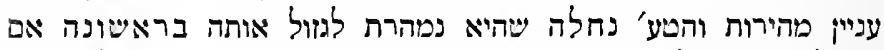

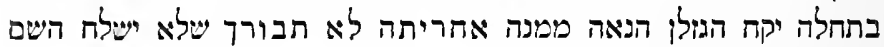

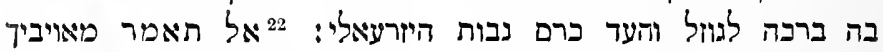

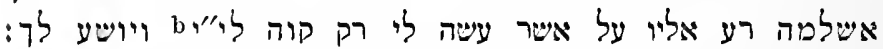

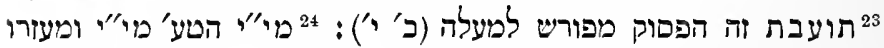

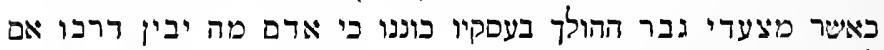

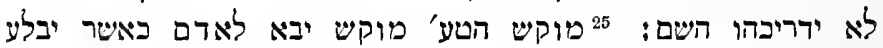

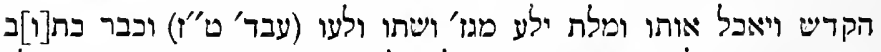

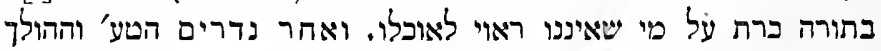

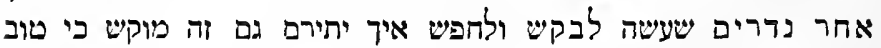

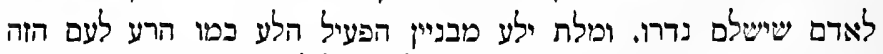

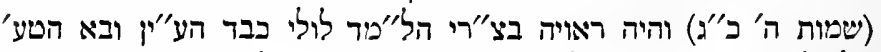

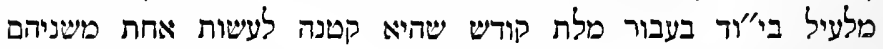

$$
\text { b כ"י, מאל ל " כ"י. }
$$

a כ"י, אלהים. 


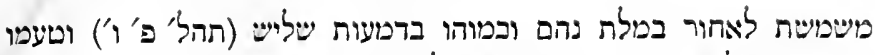

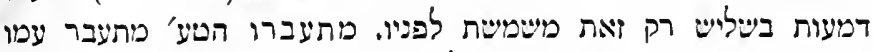

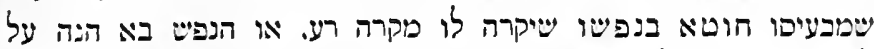

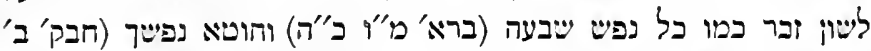

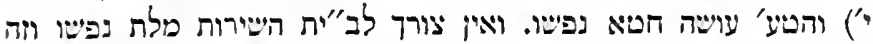

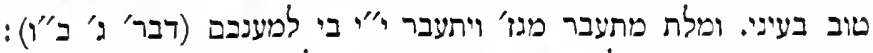

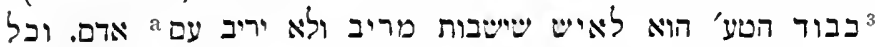

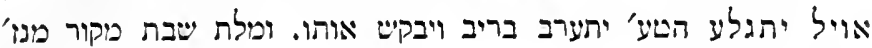

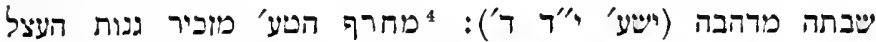

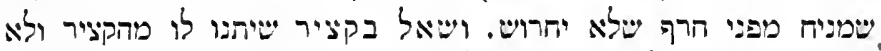

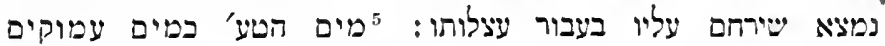

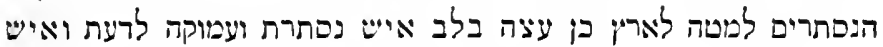

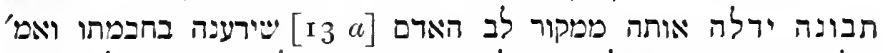

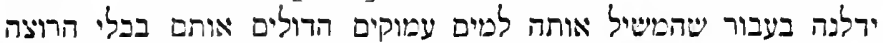

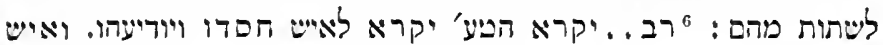

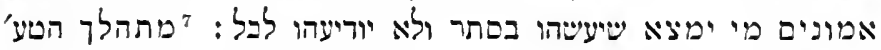

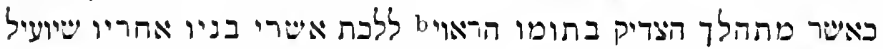

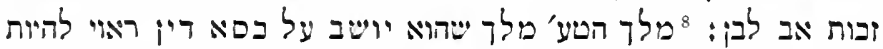

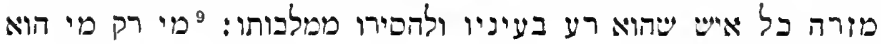

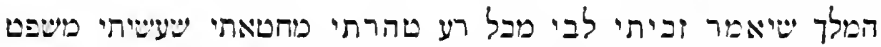
כראוי:

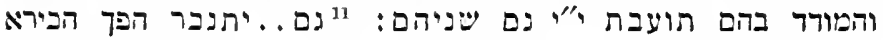

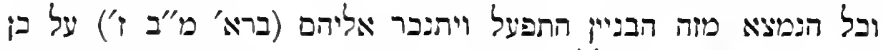

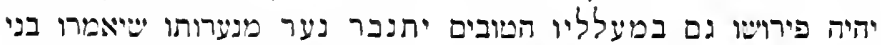

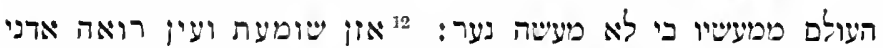

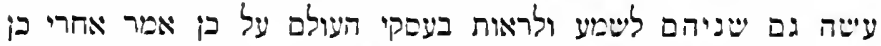

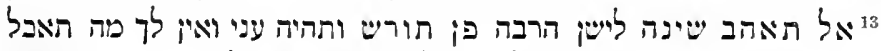

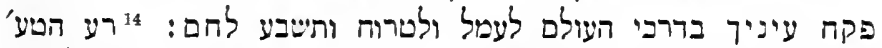

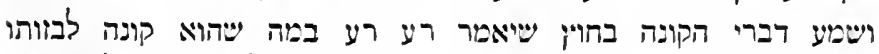

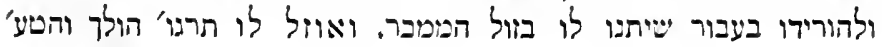




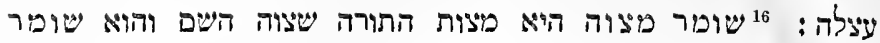

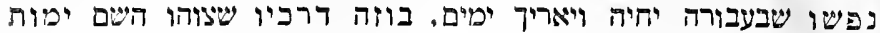

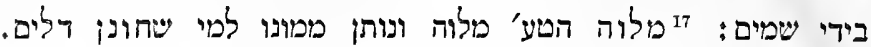

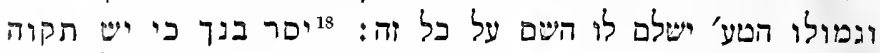

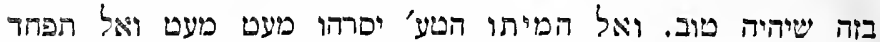

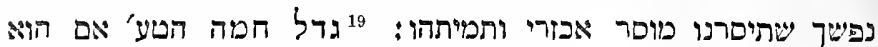

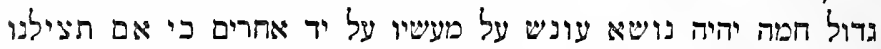

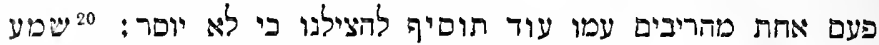

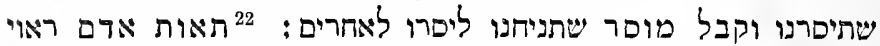

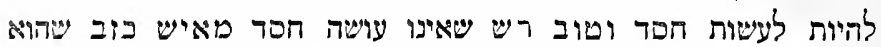

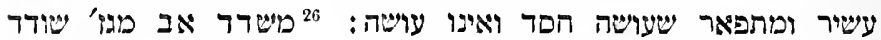

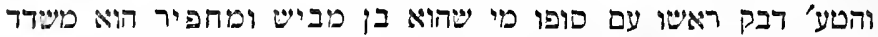

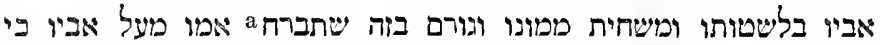

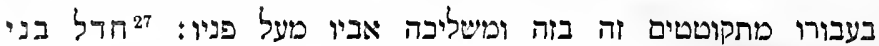

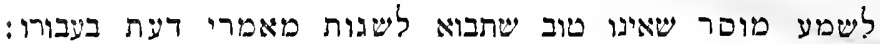

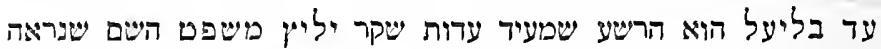

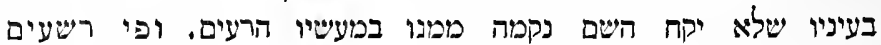

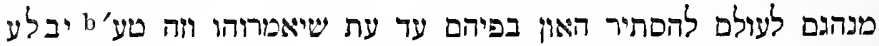

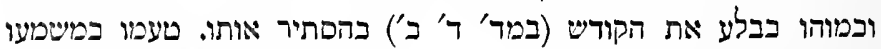

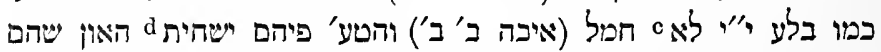

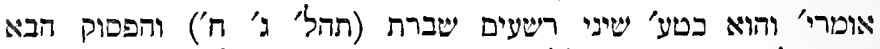

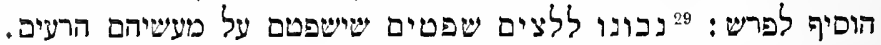

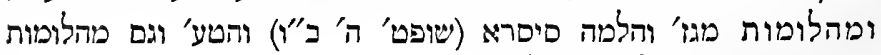

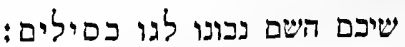

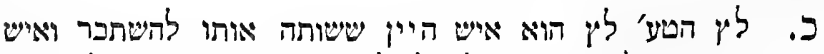

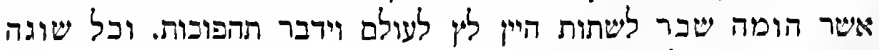

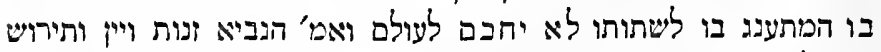

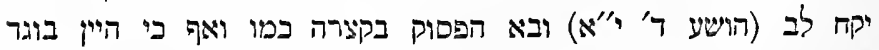

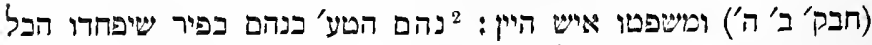

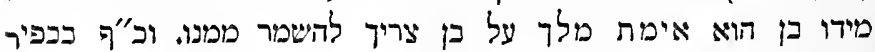

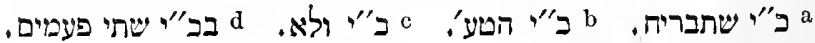




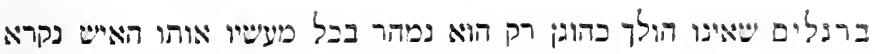

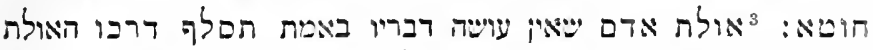

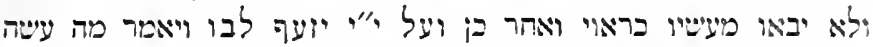

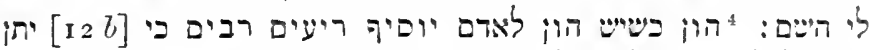

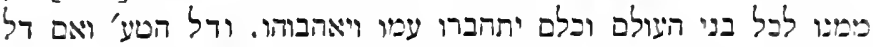

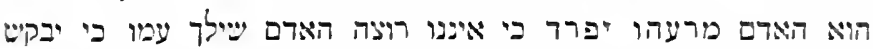

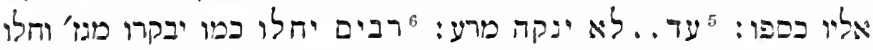

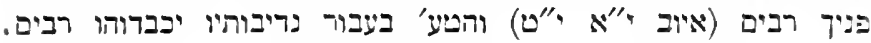

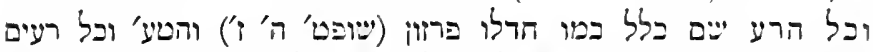

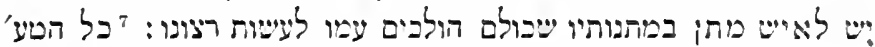

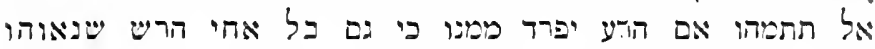

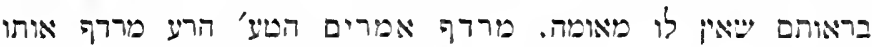

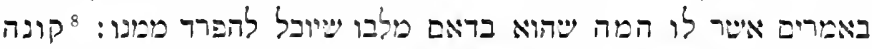

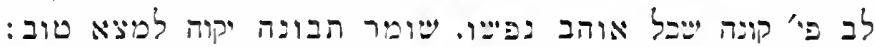

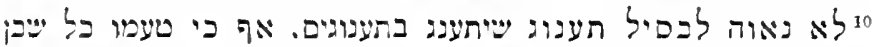

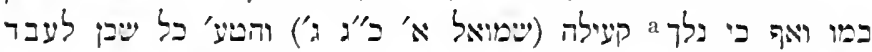
שיאיגים :אוה למישול בשרים:

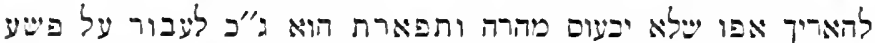

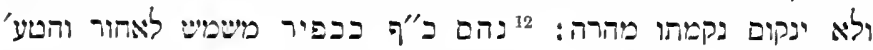

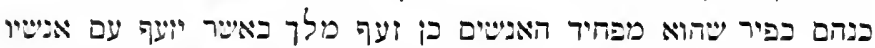

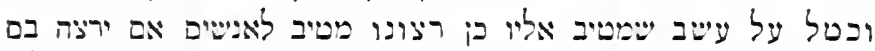

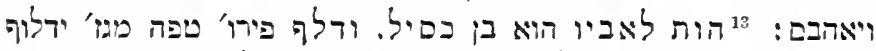

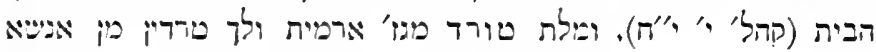

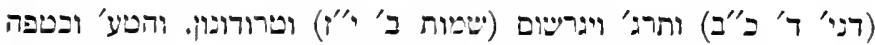

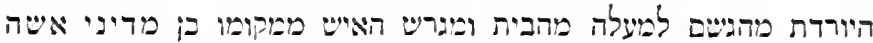

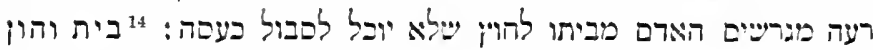

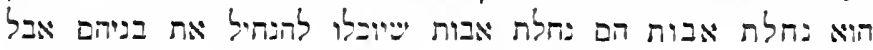

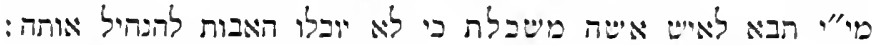

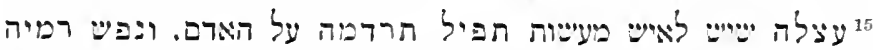

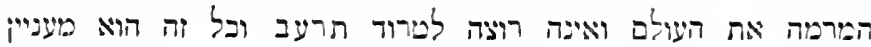


לו בכל עניינו ולפני גדולים ינחנו המתן שישב בכבים איוד ויעמד

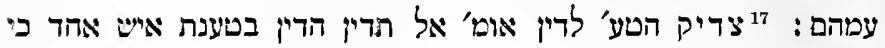

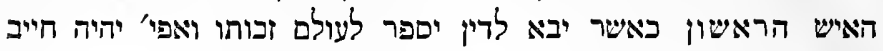

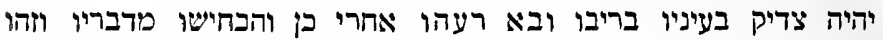

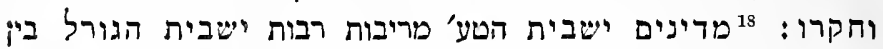

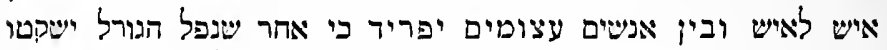

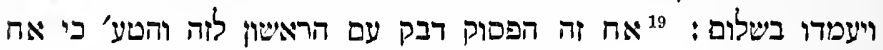

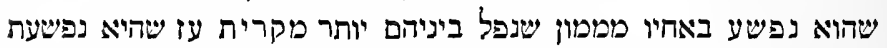

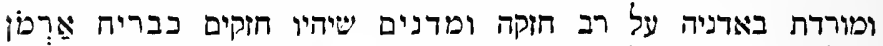

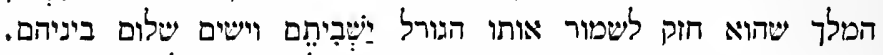

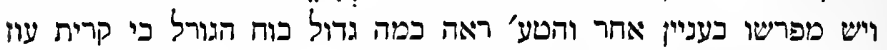

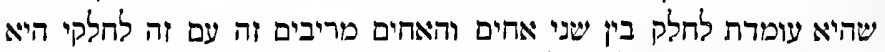

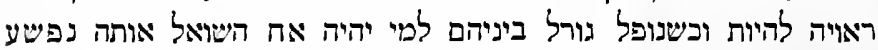

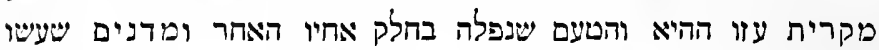

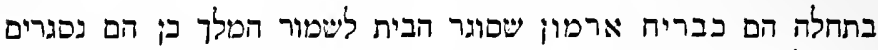

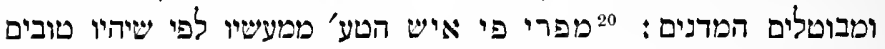

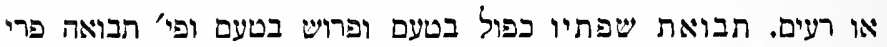

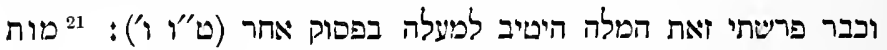

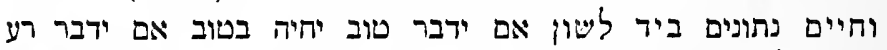

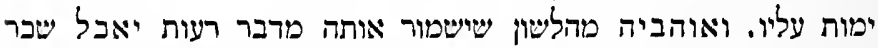

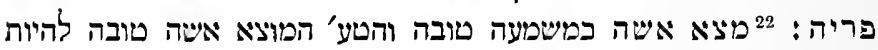

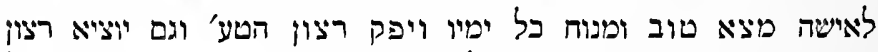

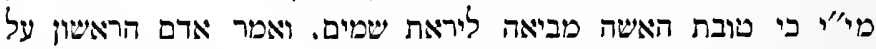

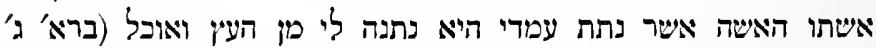

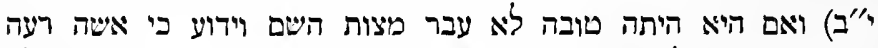

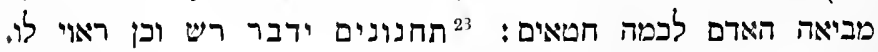

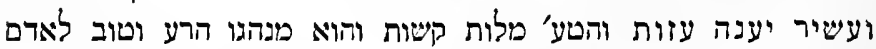

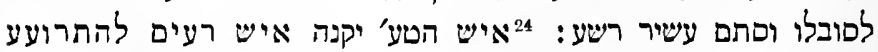

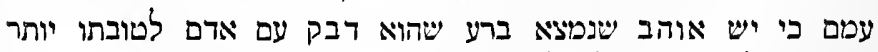

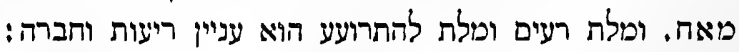

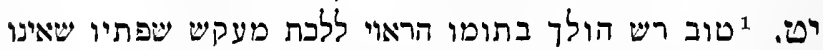

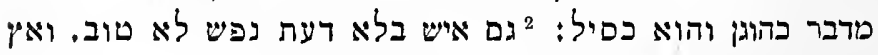




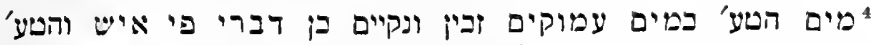

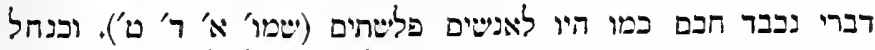
נובע כן [ [12]

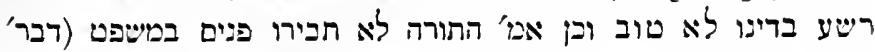

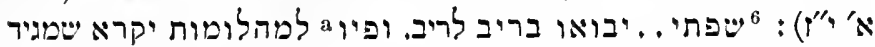

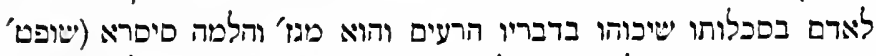

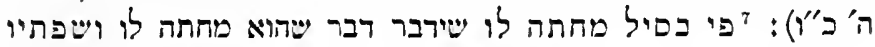

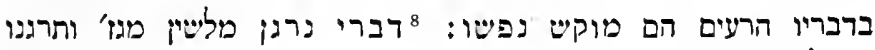

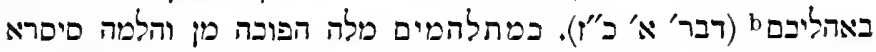

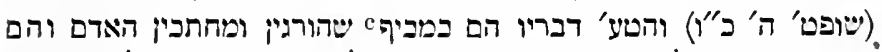

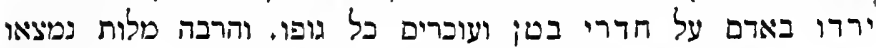

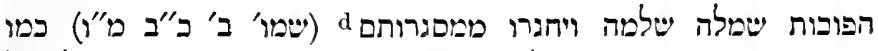

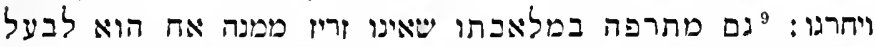

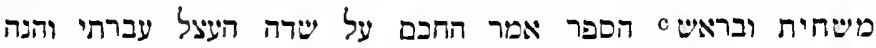

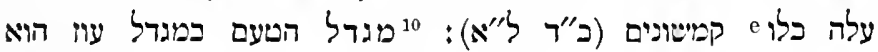

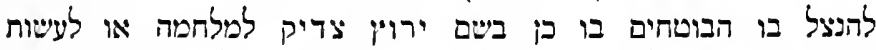

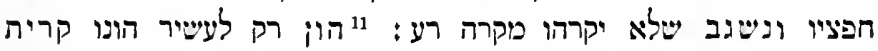

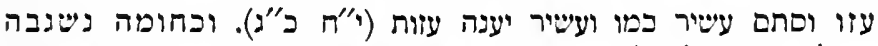

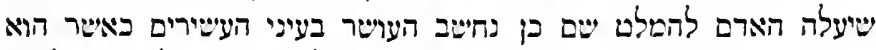

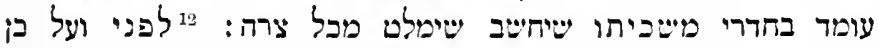

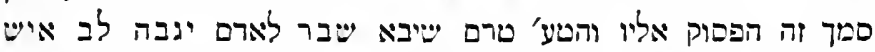

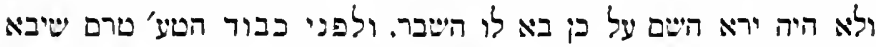

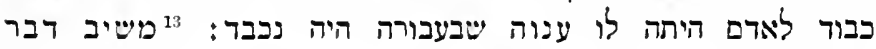

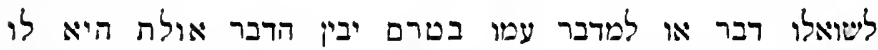

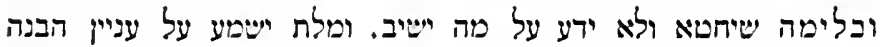

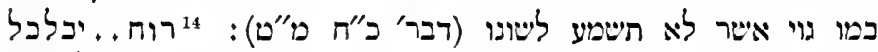

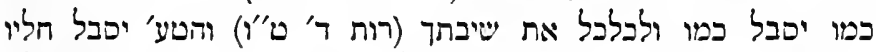

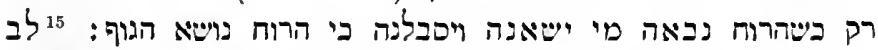

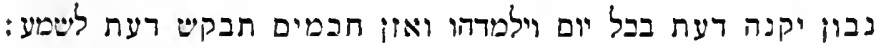

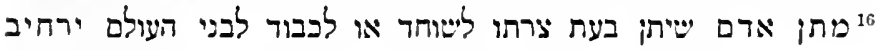

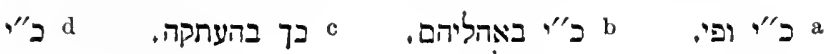

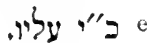

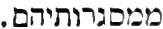




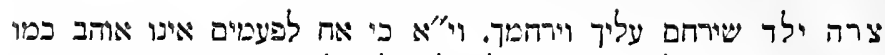

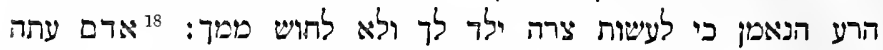

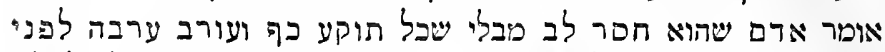

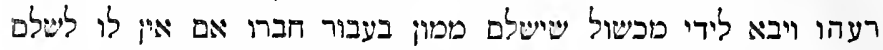

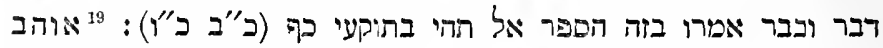

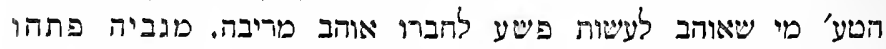

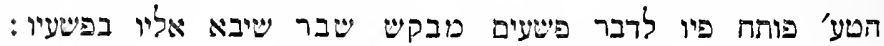

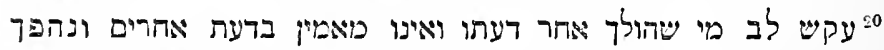

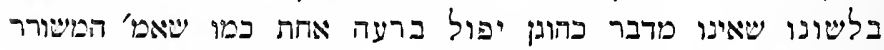

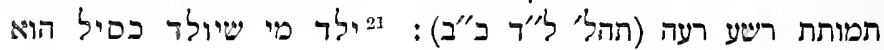

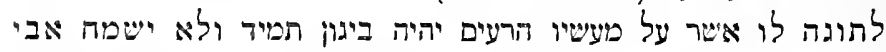

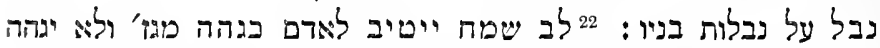

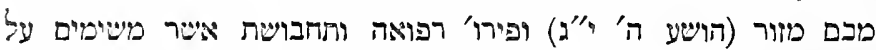

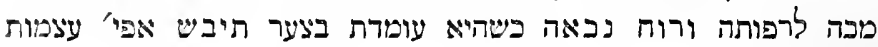

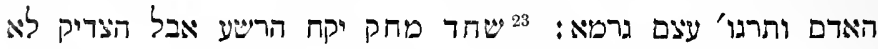

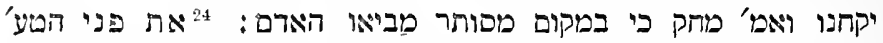

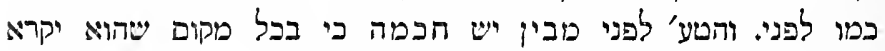

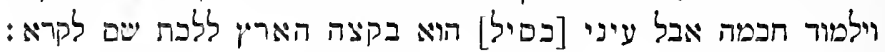

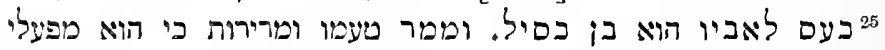

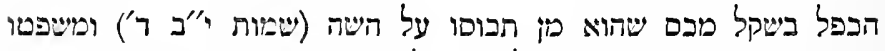

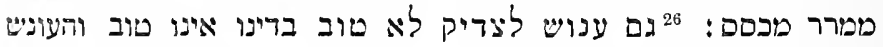

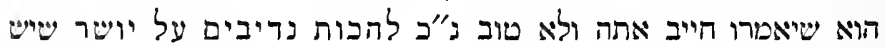

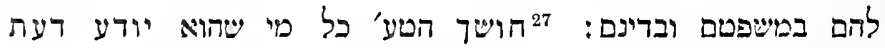

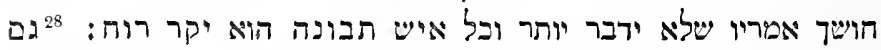

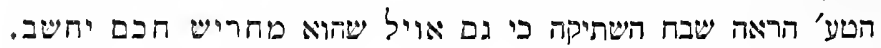

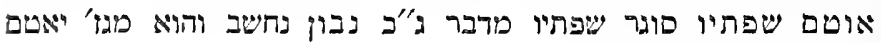

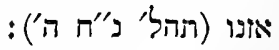

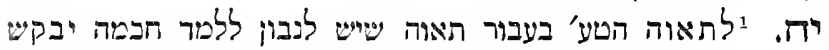

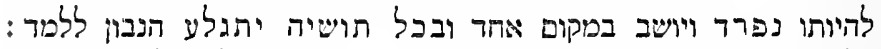

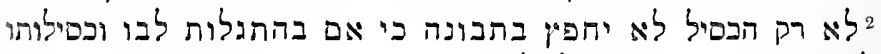

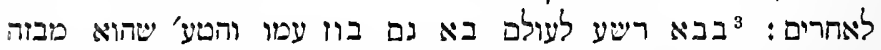

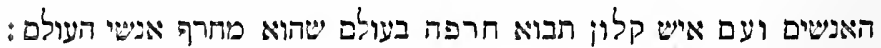


אההבה שיאהבהו בהסתיר פשעו ושונהa ברבר שתיטע בו הברו וונרו

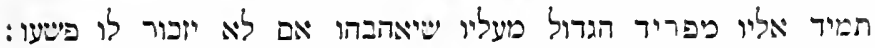

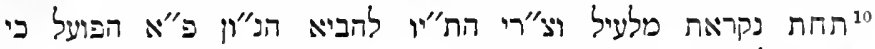

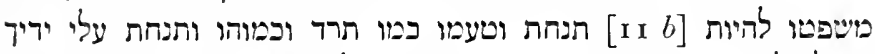

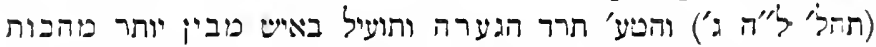

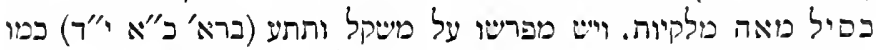

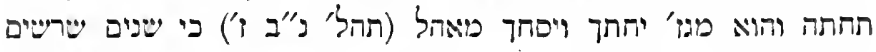

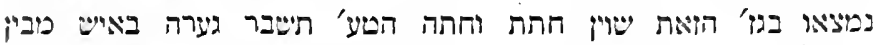

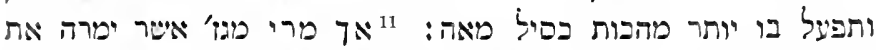

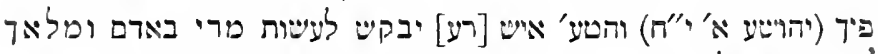

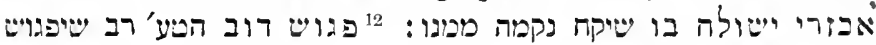

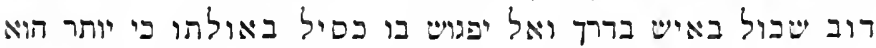

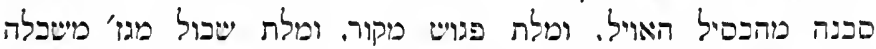

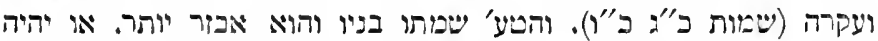

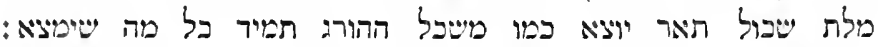

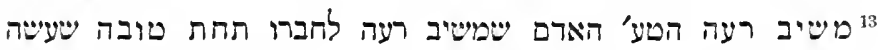

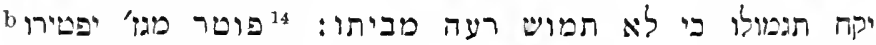

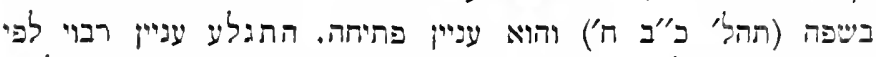

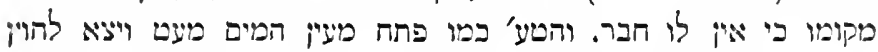

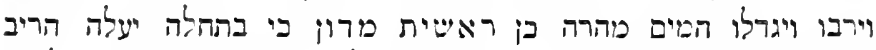

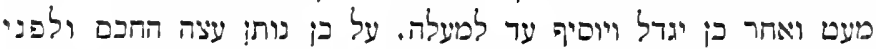

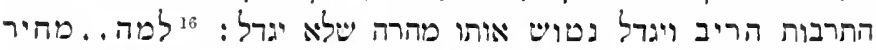

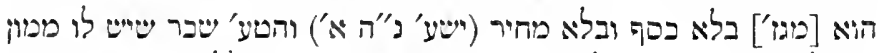

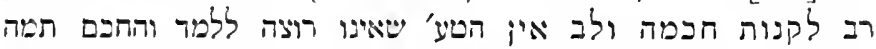

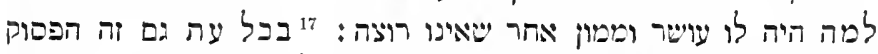

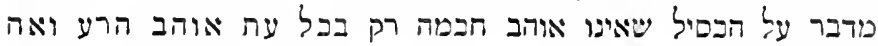

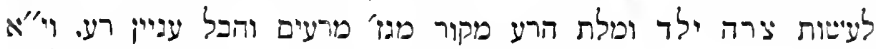

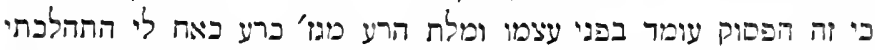

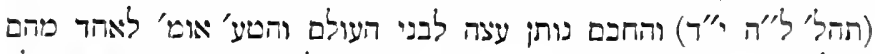

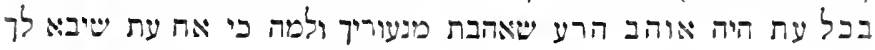




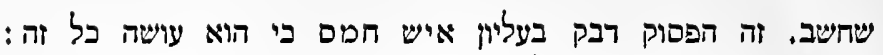

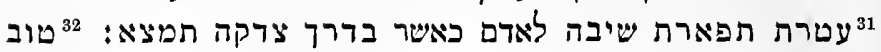

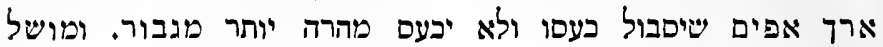

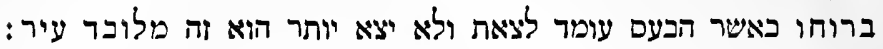

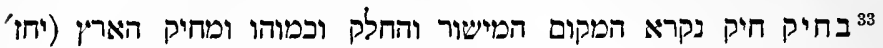

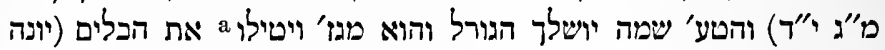

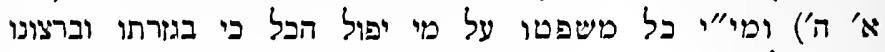
הוא הכל : המי:

יו. יטוב פת חרבה עם שלוה בה שיאכל האדם מבלי בשר וכל רבר הנאכלת עמה וכן נקרא מנחה בלא שמן חרבה (ויקרא צ' צ').

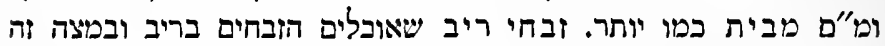

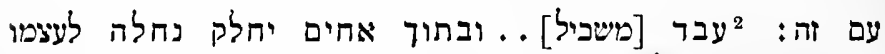

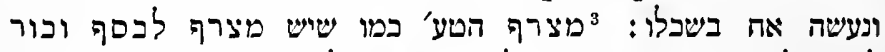

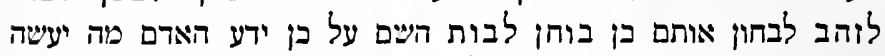

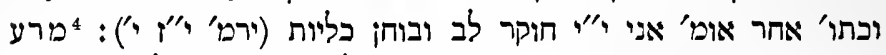

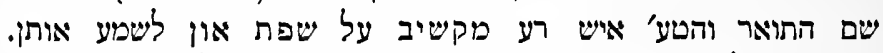

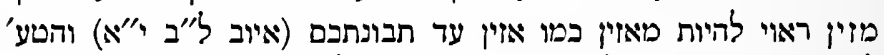

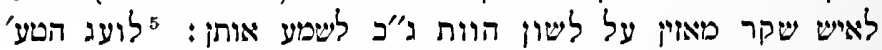

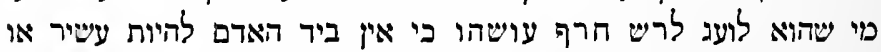

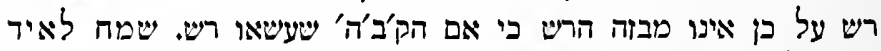

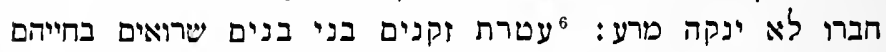

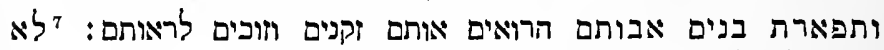

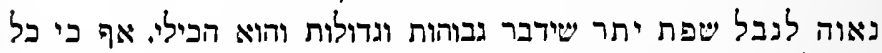

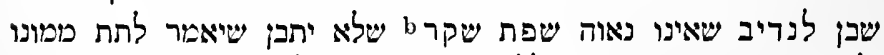

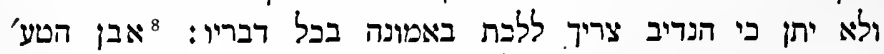

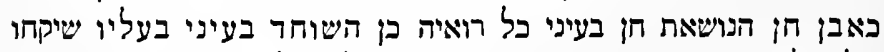

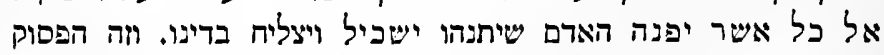

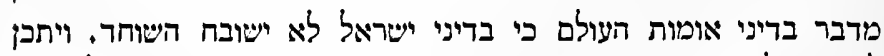

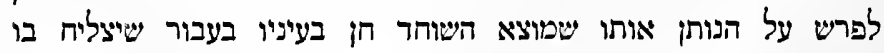
ברינו: 'מכסה פשע הטע' מסתיר הפשע שפשע בו חברו מבקש 
שמעצמו מוציא כמה דברים. ומתק שפתים יושים יוסיף לקח ובמוהו

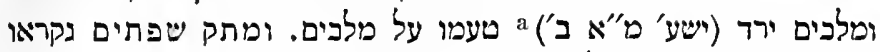

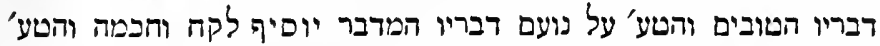

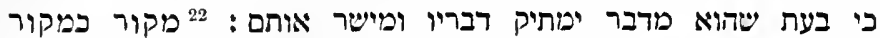

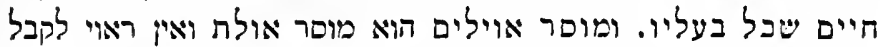

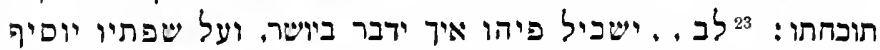

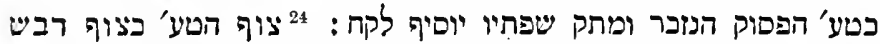

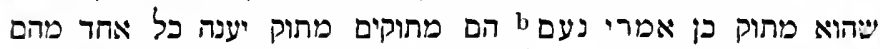

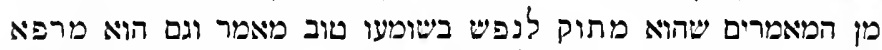

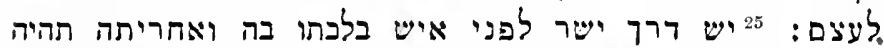

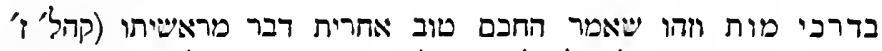

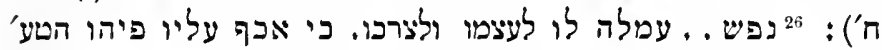

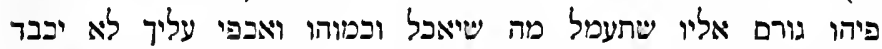

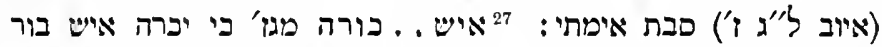

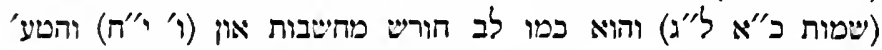

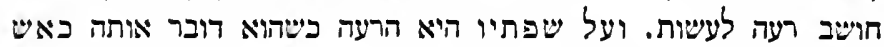

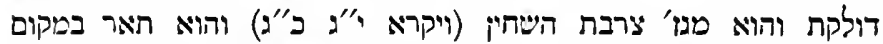

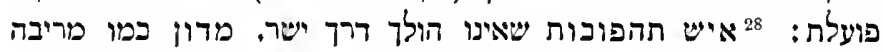

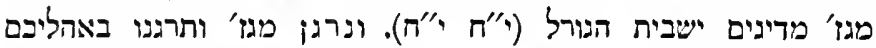

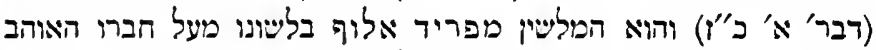

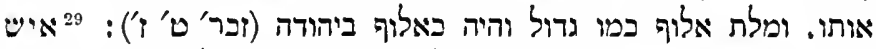

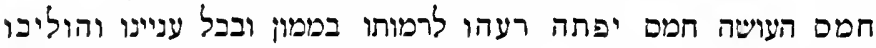

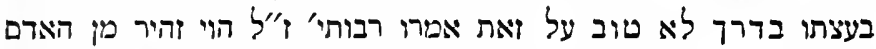

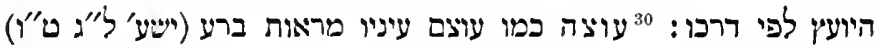

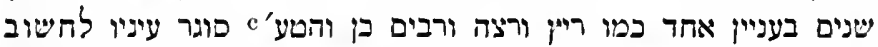

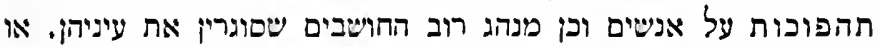

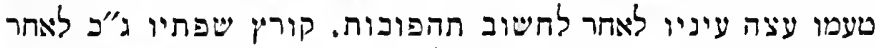

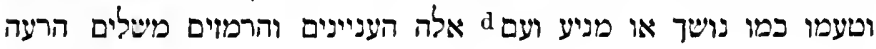

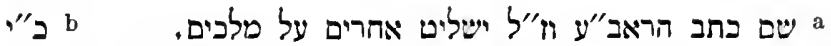

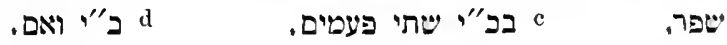




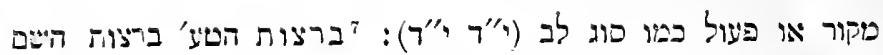

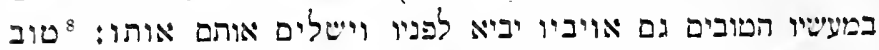

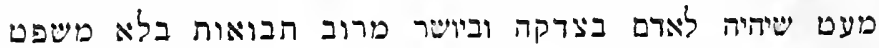

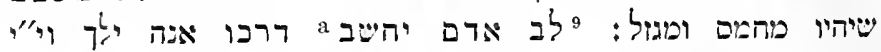

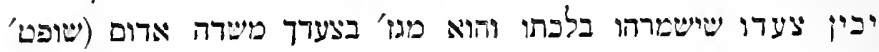

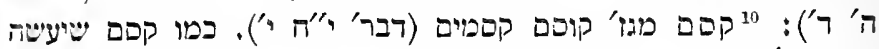

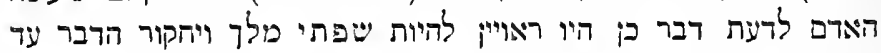

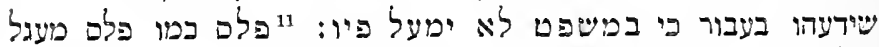

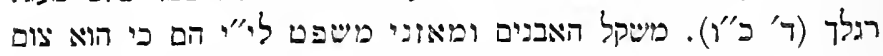

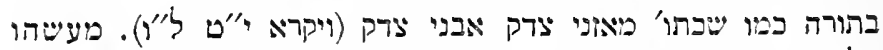

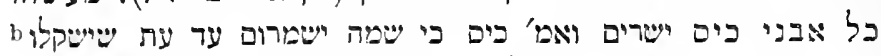

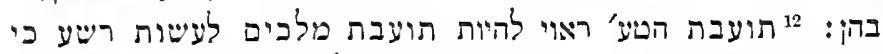

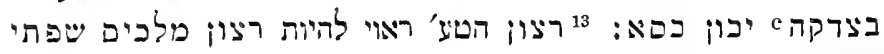

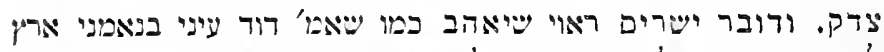

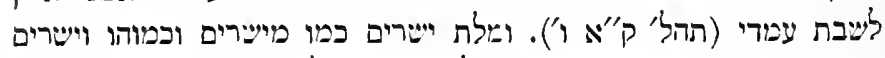

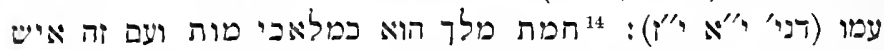

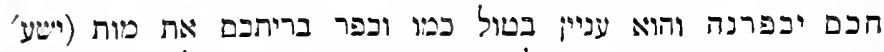

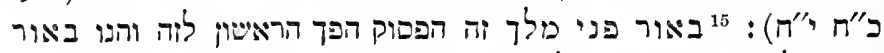

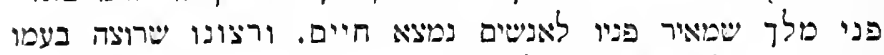

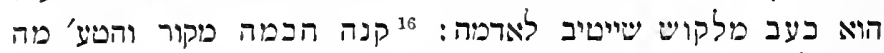

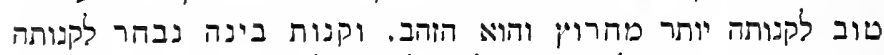

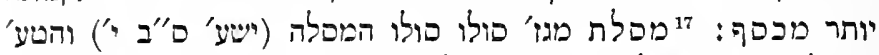

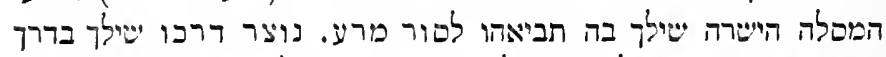

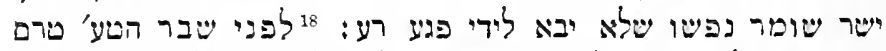

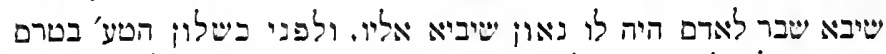

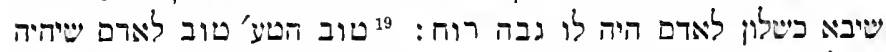

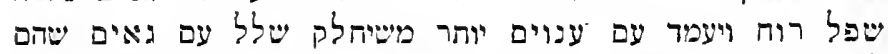
לספיםס:

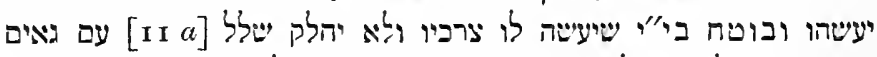

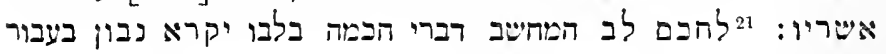

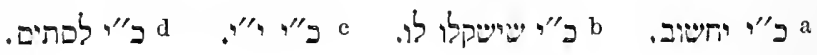


ניאומר עליהם שמי שבוצ'ע בצע והטע' הגומל משון אדם בדין שקר

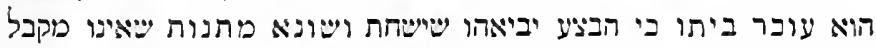

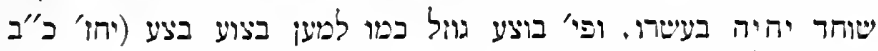

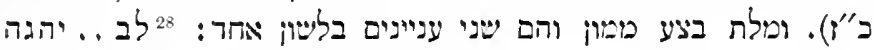

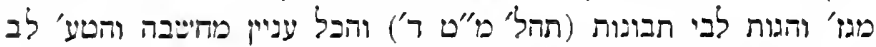

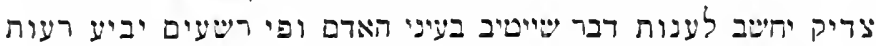

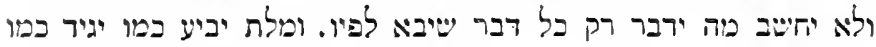

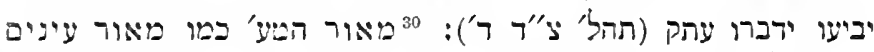

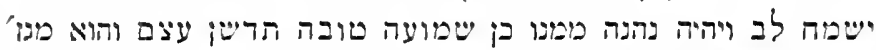

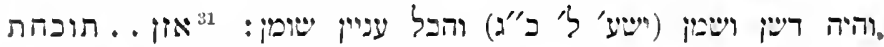

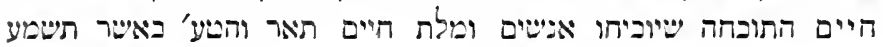

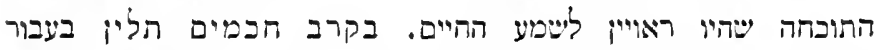

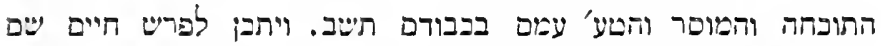

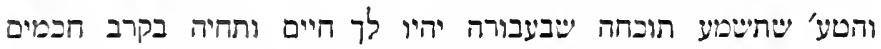
תלין בעבורה והצי הפטוק בפירויט הראשיון:

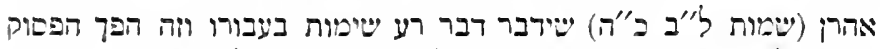

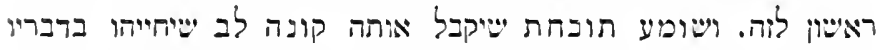

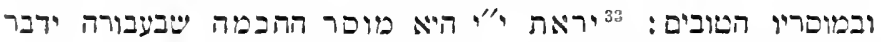

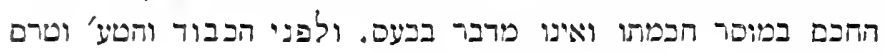

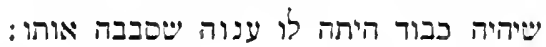

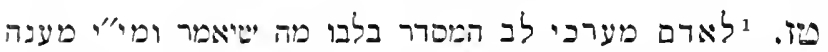

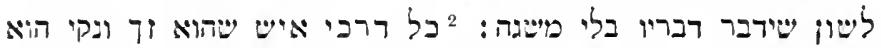

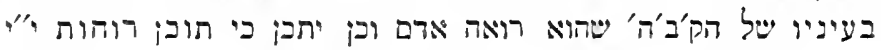

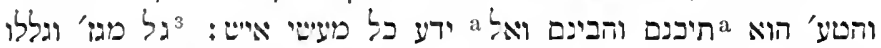

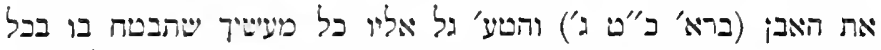

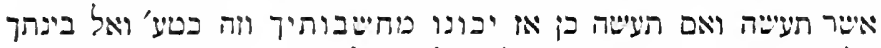

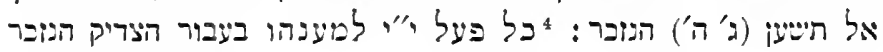

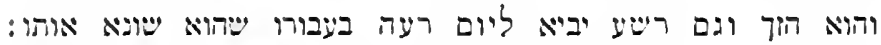

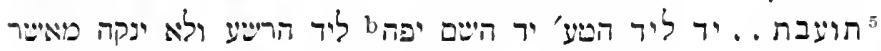

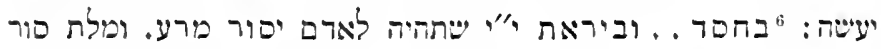




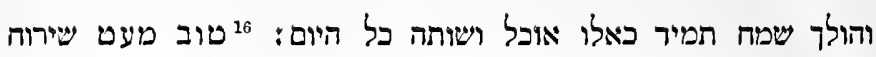

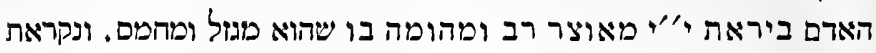

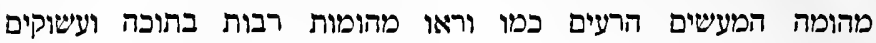

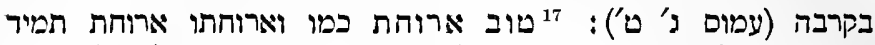

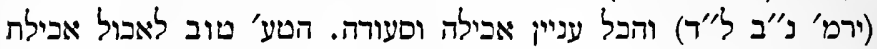

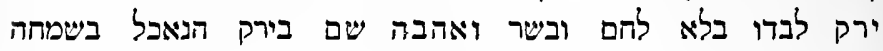

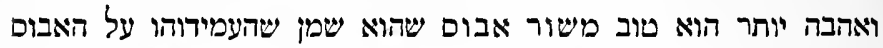
לאכל הרבה ער שהיהם שמן ושנאה בו משור משור הנאכל בקטטה עמוא ובמריבה:

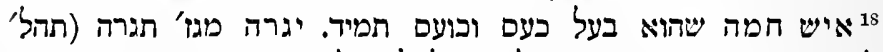

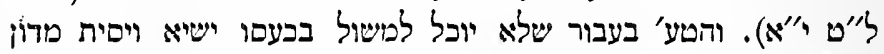

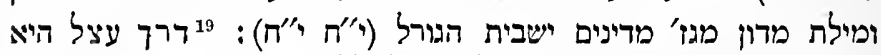

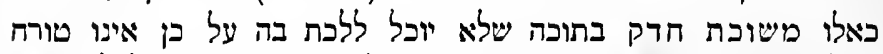

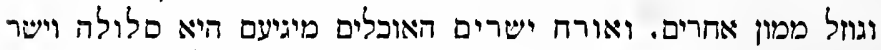
להם: ${ }^{20}$

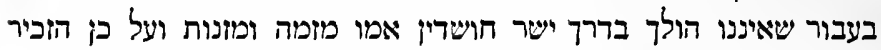

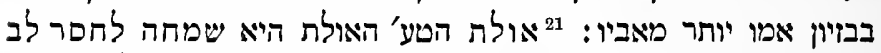

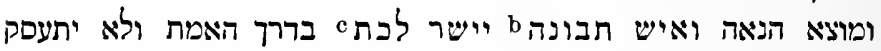
באולת:

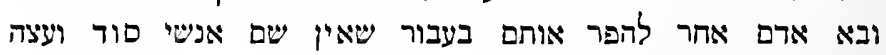

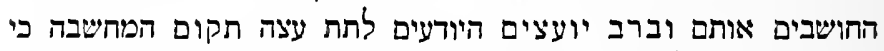

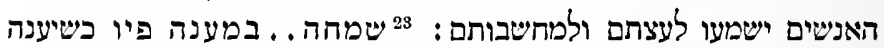

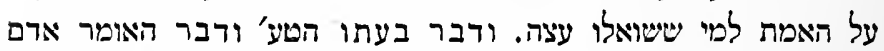

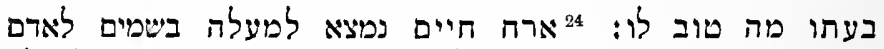
משכיל כלומ' [10]

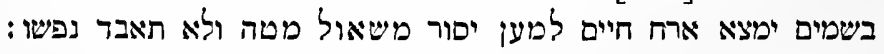

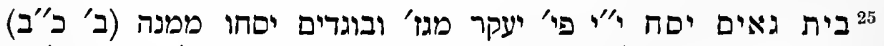

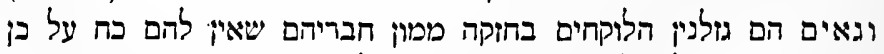

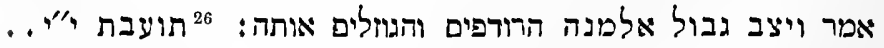

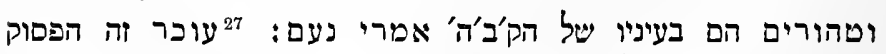

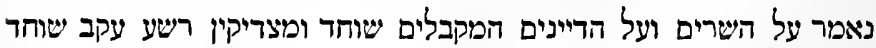

a ב"י שהיה שהיה. ב ב"י תבונות. עיין י"א י"ב. ב"י ללכת. 
ויסלק דברי צריקים (שמות כ"ג ח') והטע' ומי שיש לו עווח בלשון

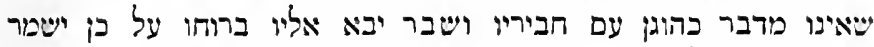

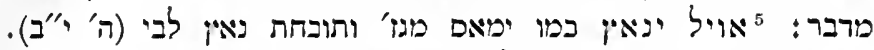

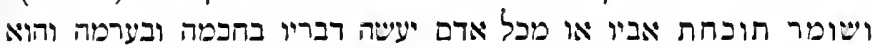

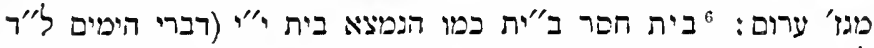

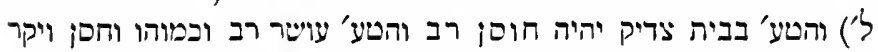

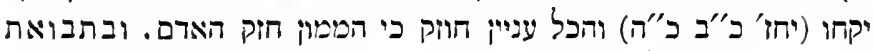

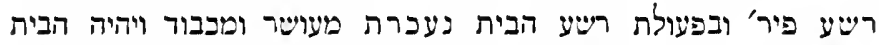

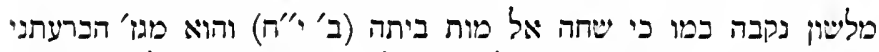

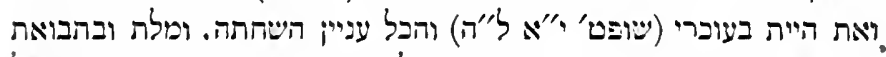

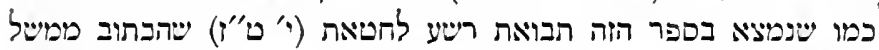

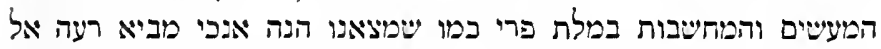

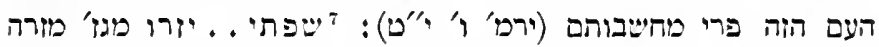

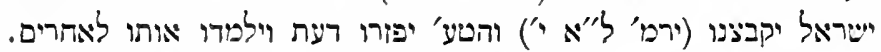

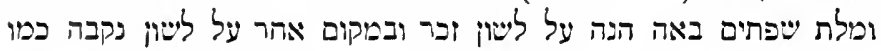

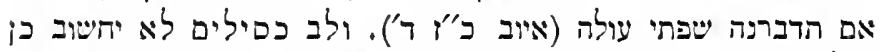

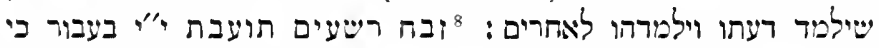

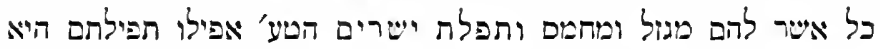

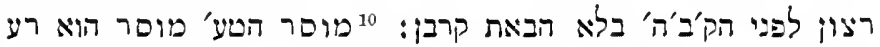

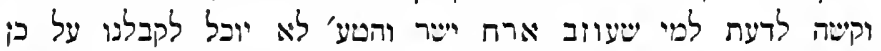

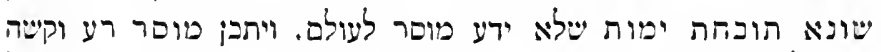

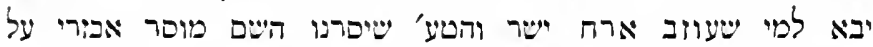

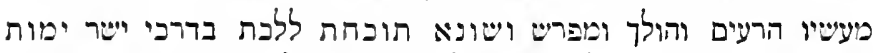

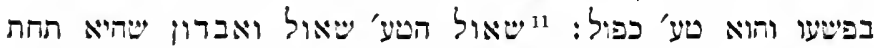

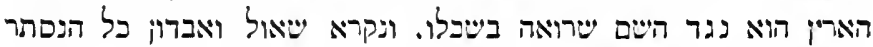

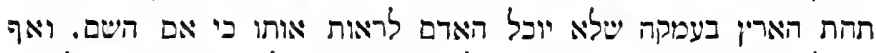

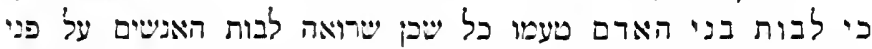

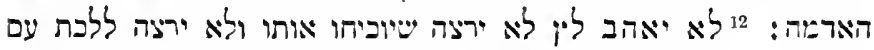

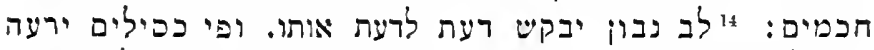

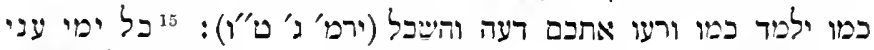

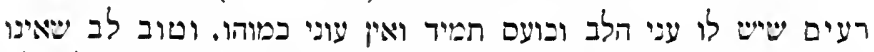

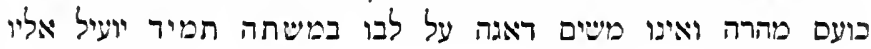




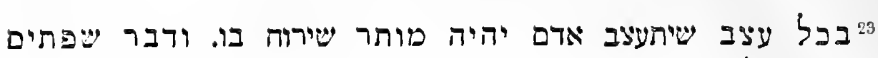

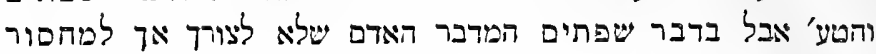
כמו שנ' בזה הספר ברוב דברים לא יחדל פישע ("' י"טי):

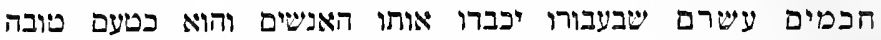

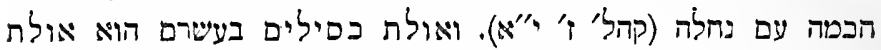

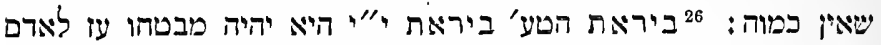

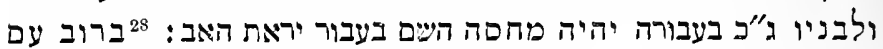

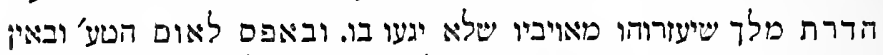

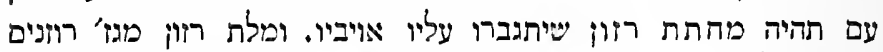

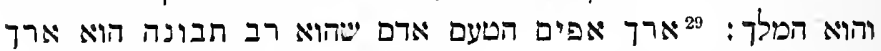

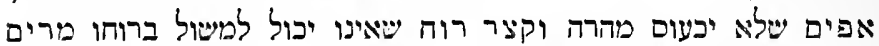

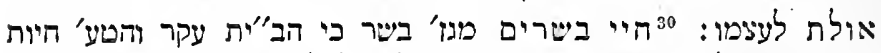

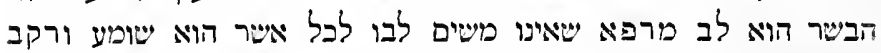

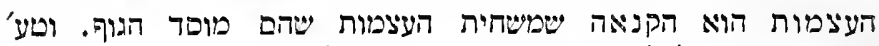

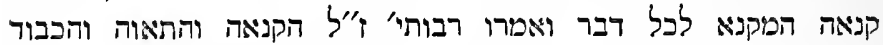
מוציאין את הארם מן העולם:

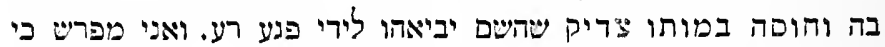

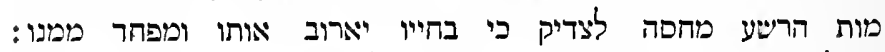

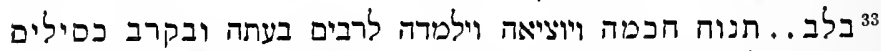
תורע בכל עת:

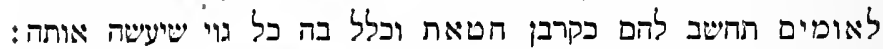

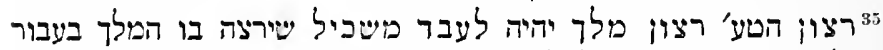

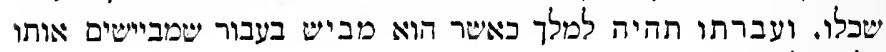

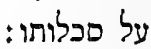

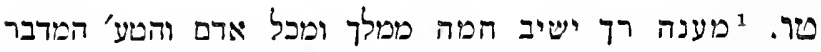

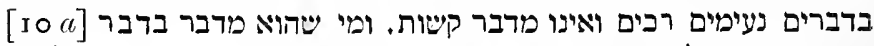

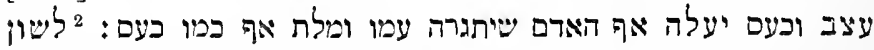
חכמים תיטיב דצת מתקנת דבריה בחכמה איך ייטיבו בעיני האדם.

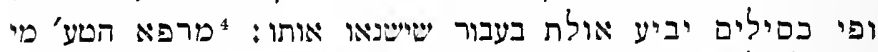

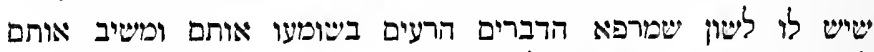

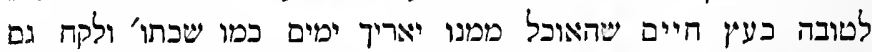

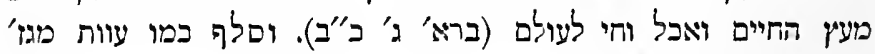




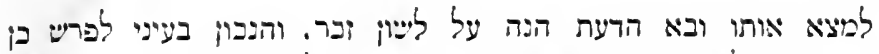

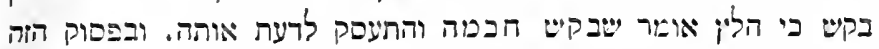

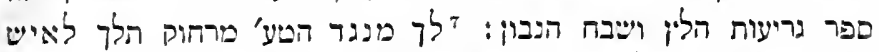

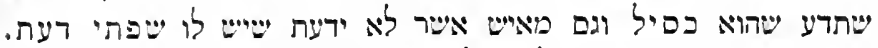

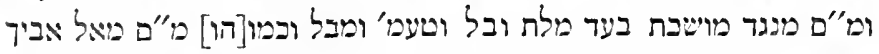

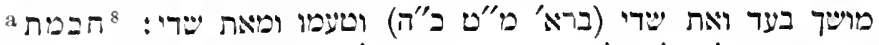

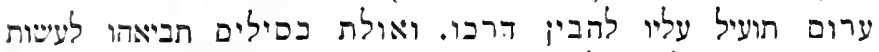

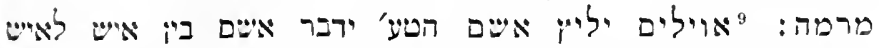

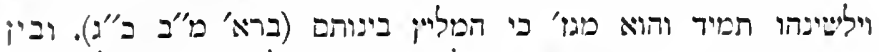

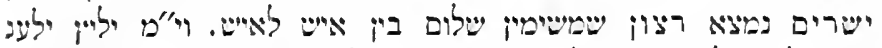

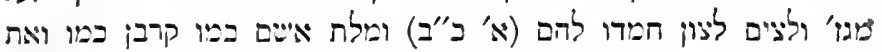

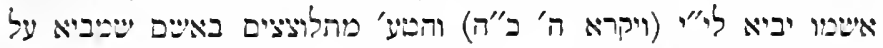

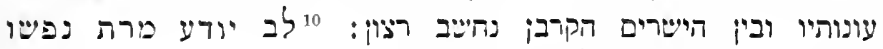

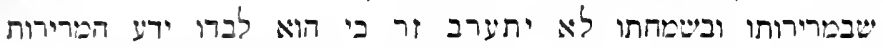

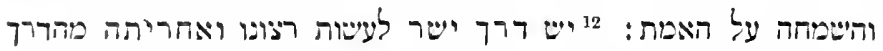

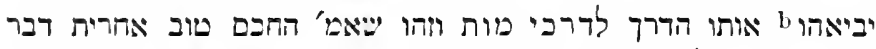

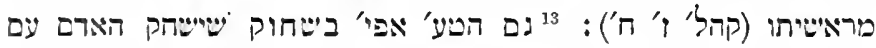

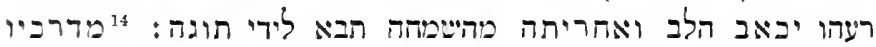

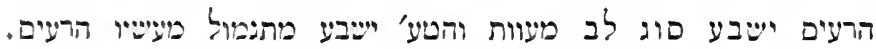

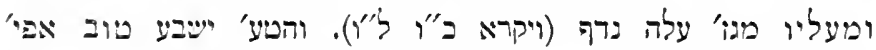

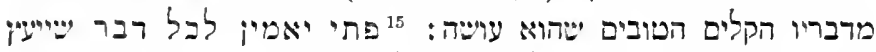

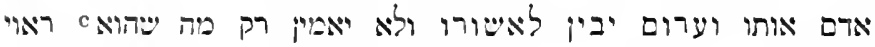

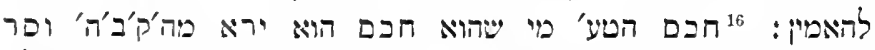

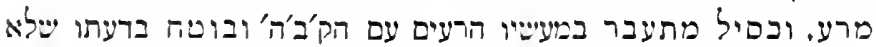

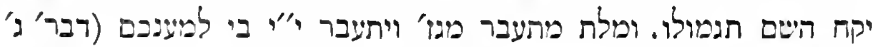

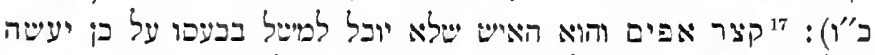

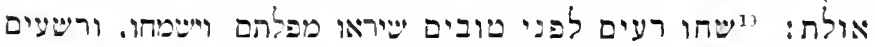

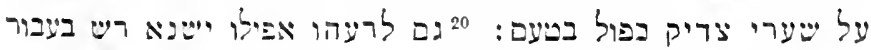

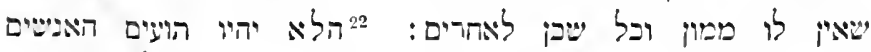

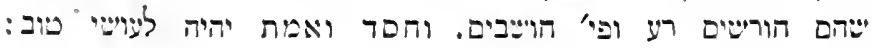

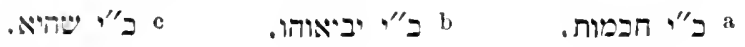




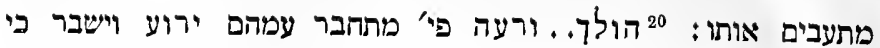

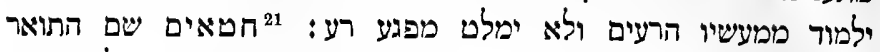

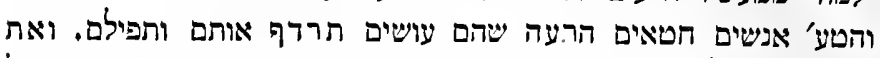

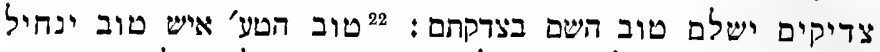

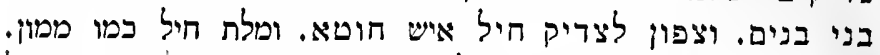

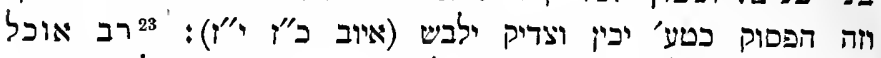

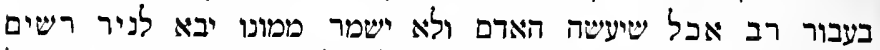

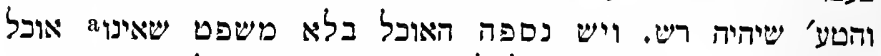

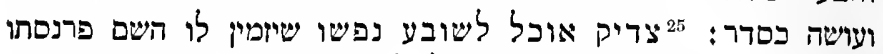

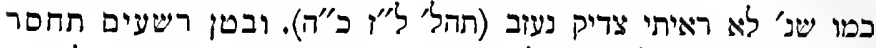

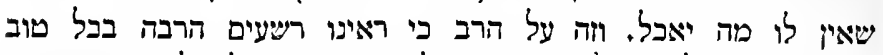

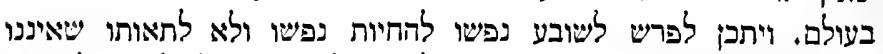

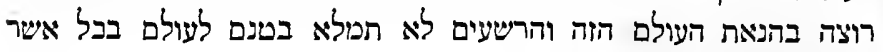

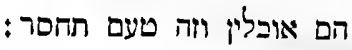

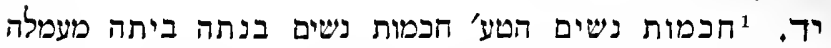

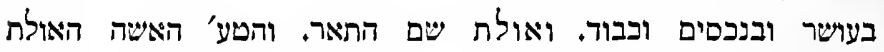

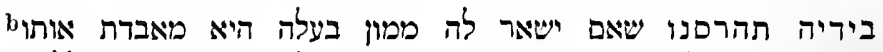

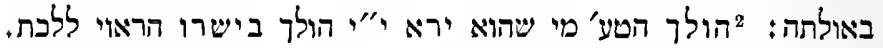

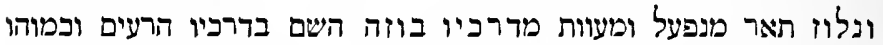

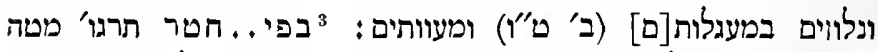

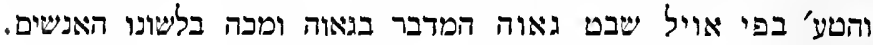

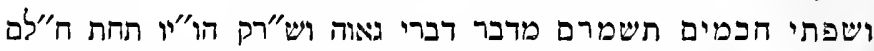

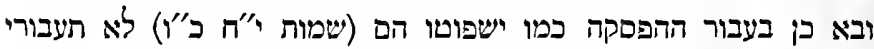

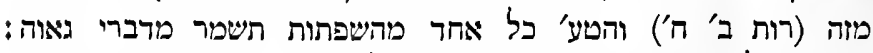

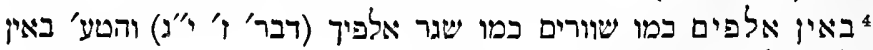

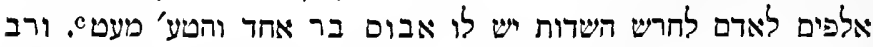

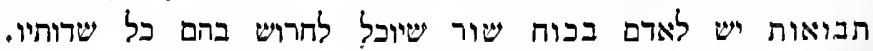

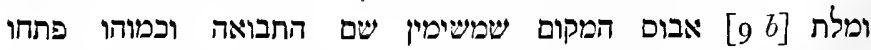

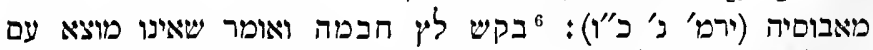

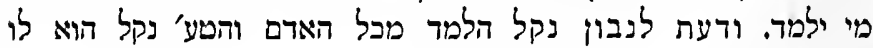

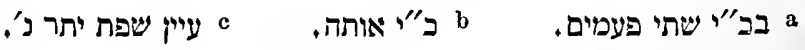




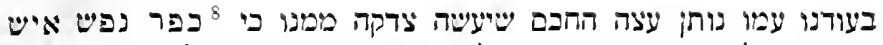

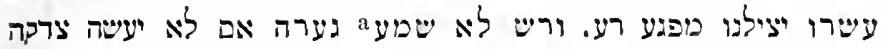

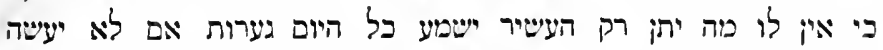

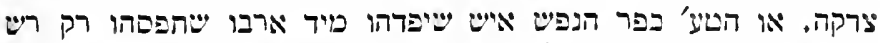

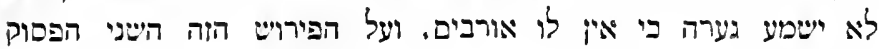

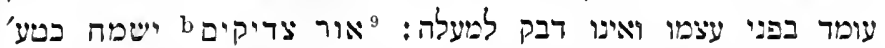

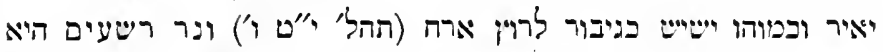
הנישמה המאירה פגי הגוף בנר:

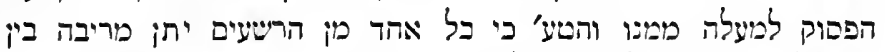

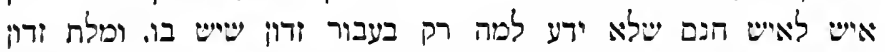

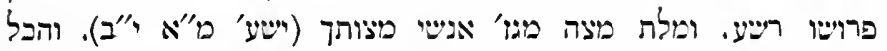

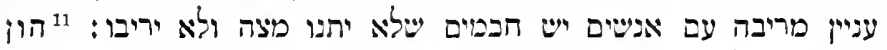

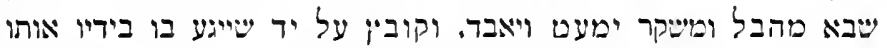

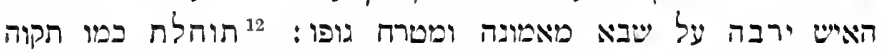

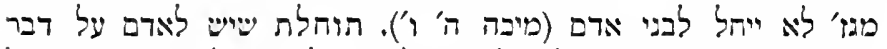

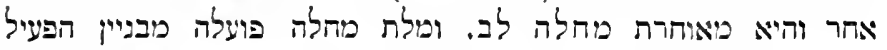

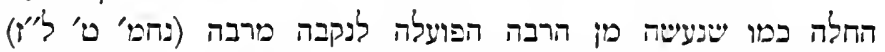

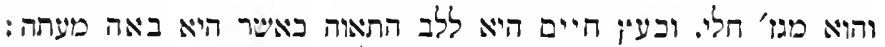

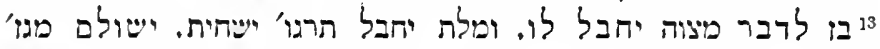

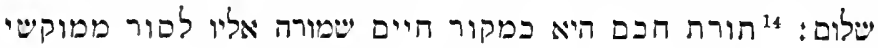

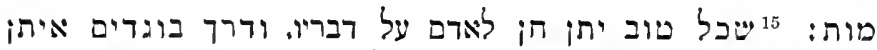

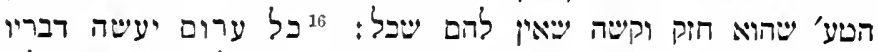

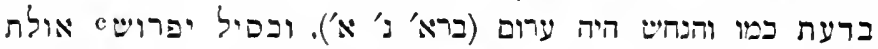

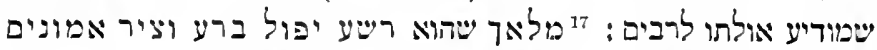
הוא מרפה למפאישלהו:

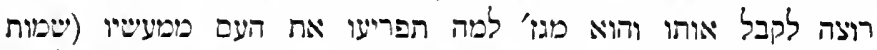
ה' ד'):

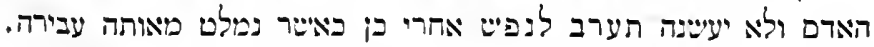

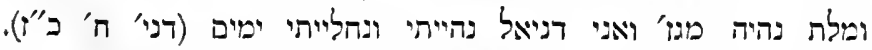

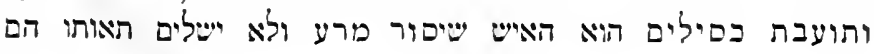

c כ"י, פירושי. 


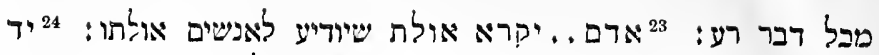

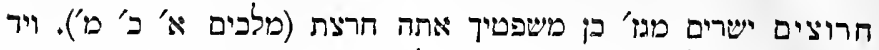

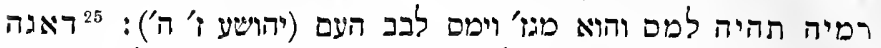

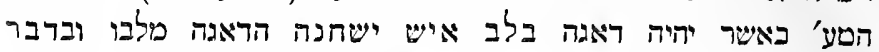

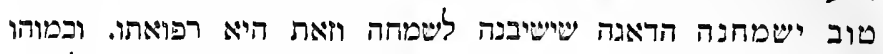

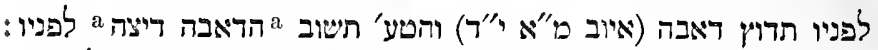

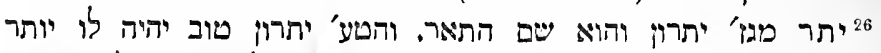

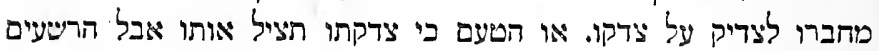

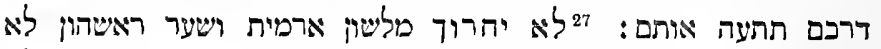

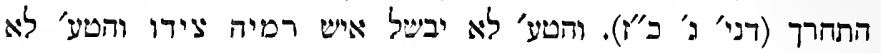

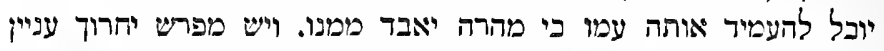

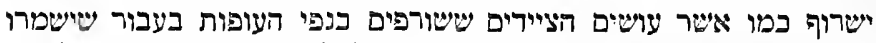

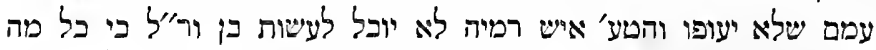

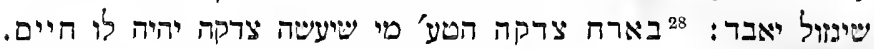

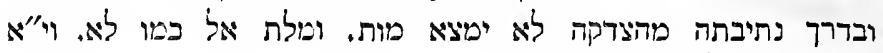

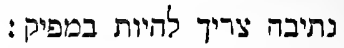

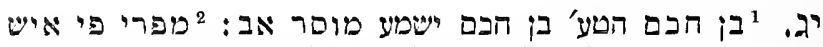

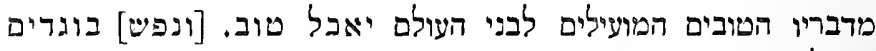

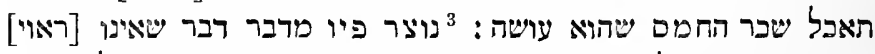

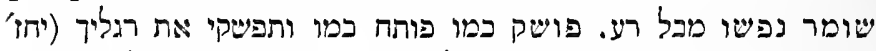

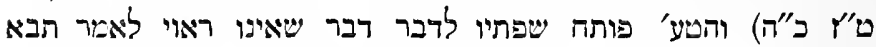

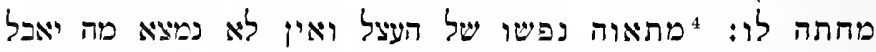

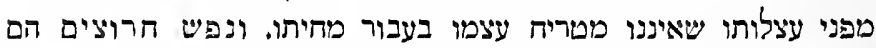

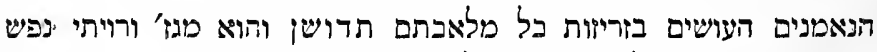

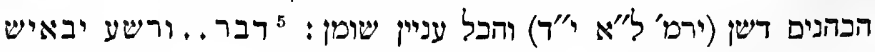

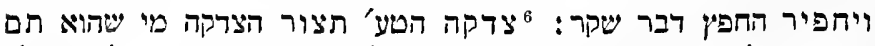

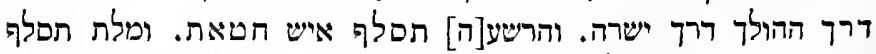
כמו תעות כמו ויסלף [9aר

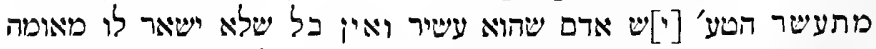

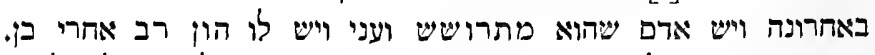

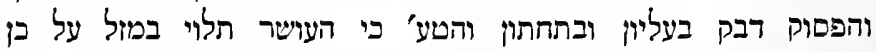


שלבו מעוות: 21 יד ליד לא ינקה אישי רע שיאם יעשה הוא רע מיד

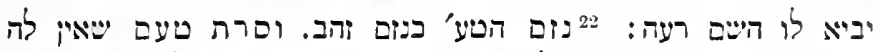

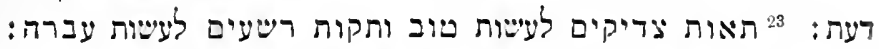

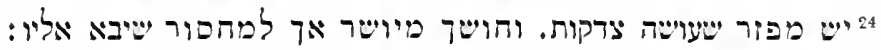

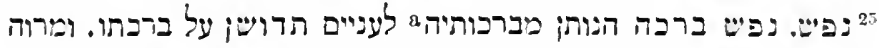

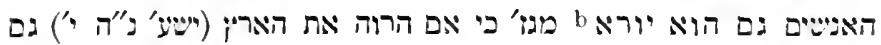

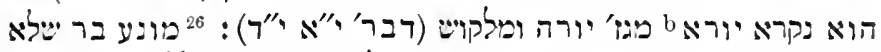

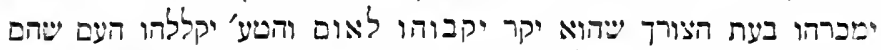

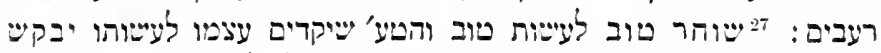

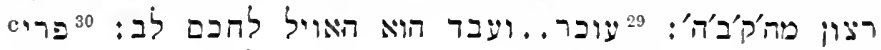

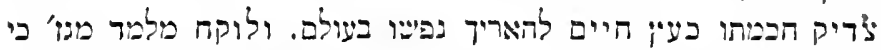

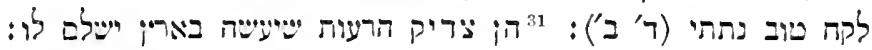

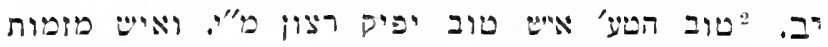

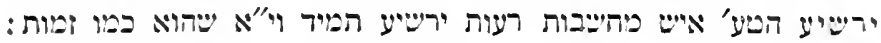

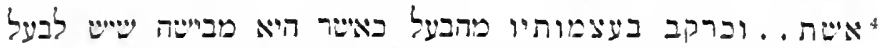

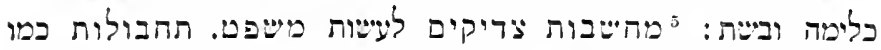

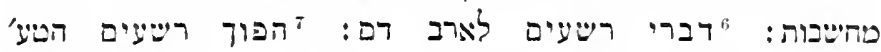

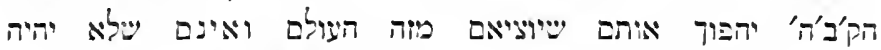

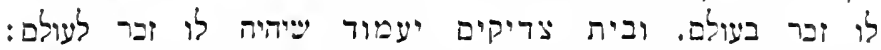

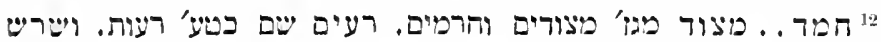

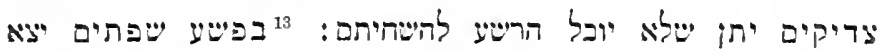

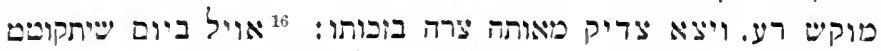

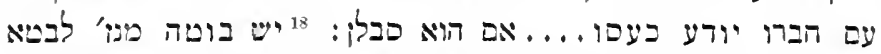

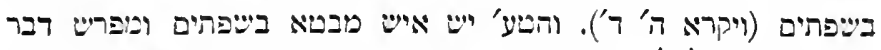

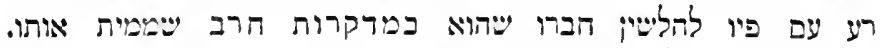

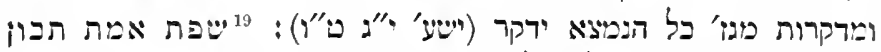

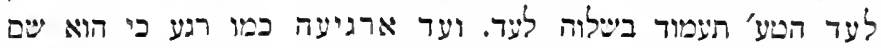

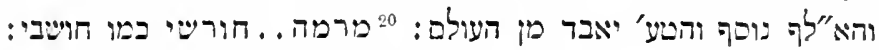

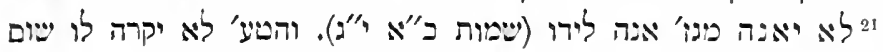

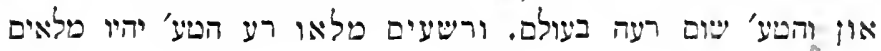

$$
\text { a כ" כ"י מברכותיך. }
$$


לשום שלום בין אייש לאיש. ופי רשעים ידבר תהפוכות בין איש: לאיש: לישום

יאה.

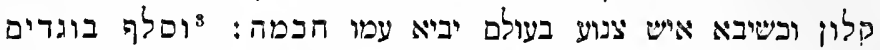

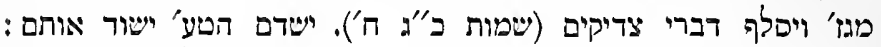

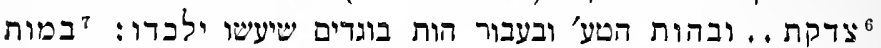

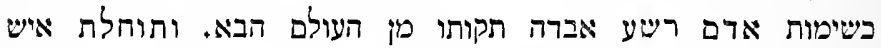

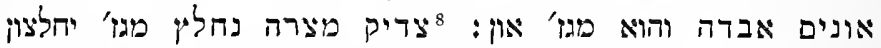

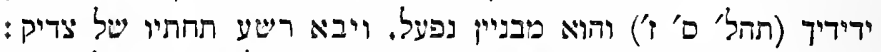

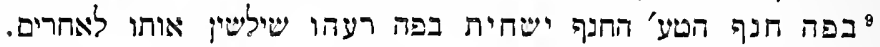

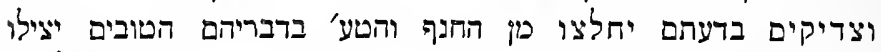

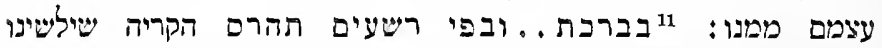
האדם אשר בה: משים

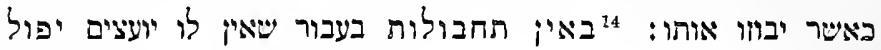

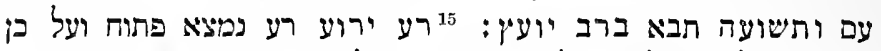

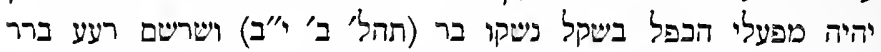

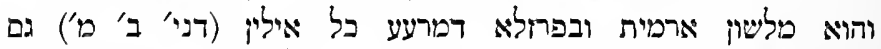

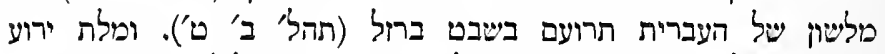

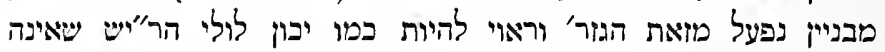

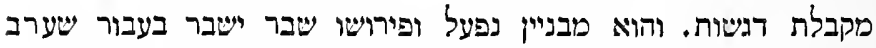

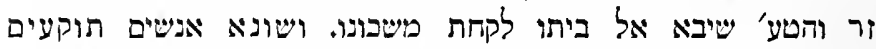

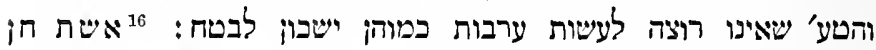

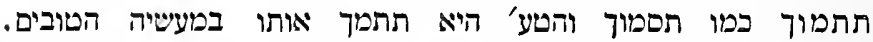

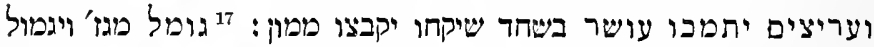

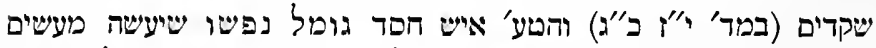

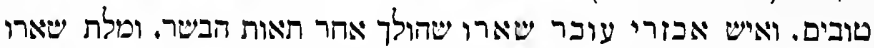

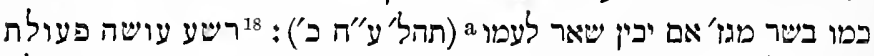

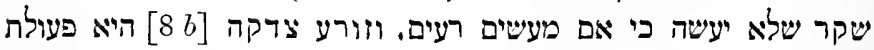

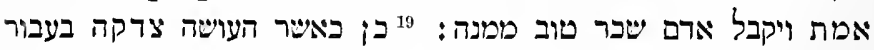

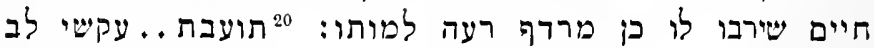




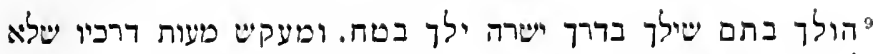

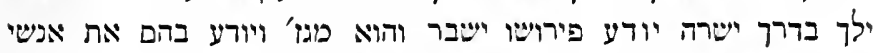

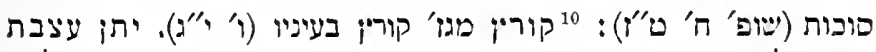

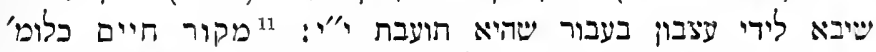

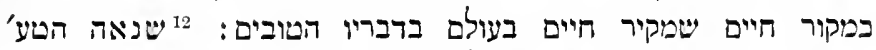

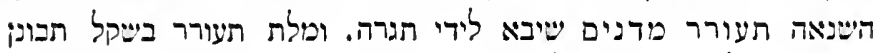

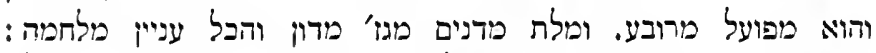

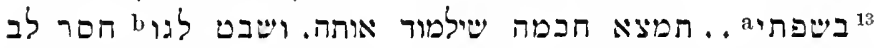

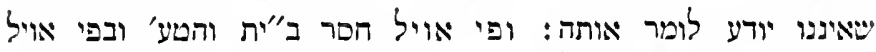

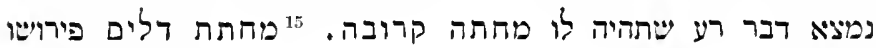

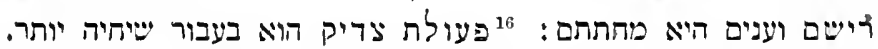

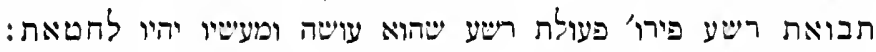

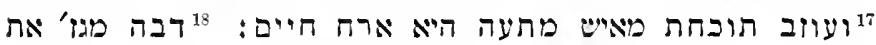

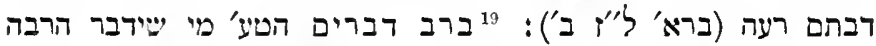

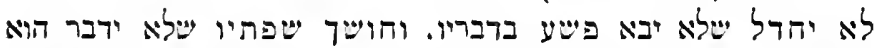

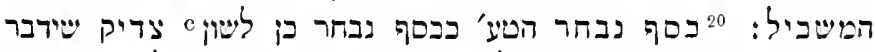

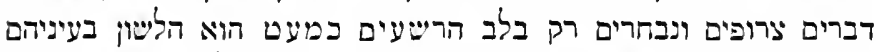

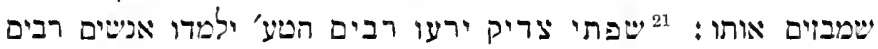

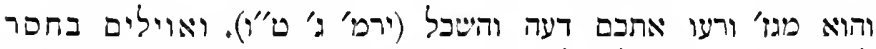

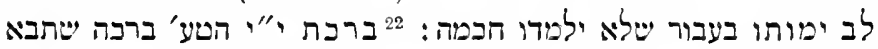

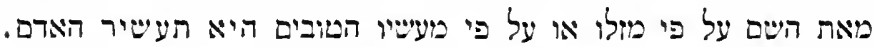

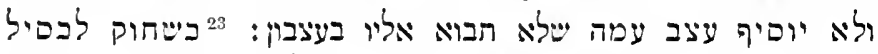

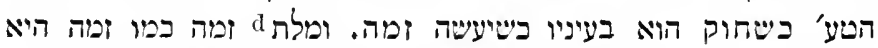

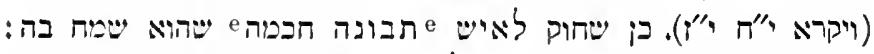

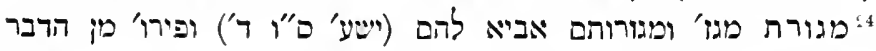

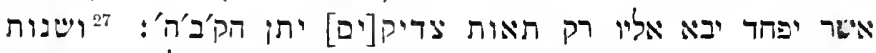

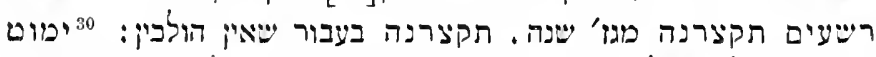

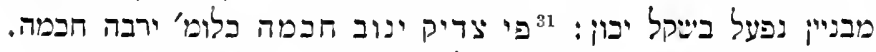

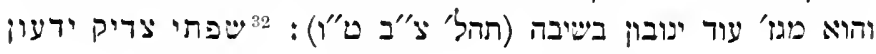

בכ"י כים

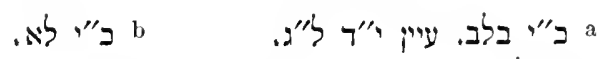


(קהל' ה' י"ד) שהוא מקום מן: 'עים עובו הטע' עובו האנשים פתאים

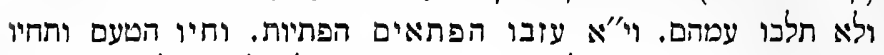

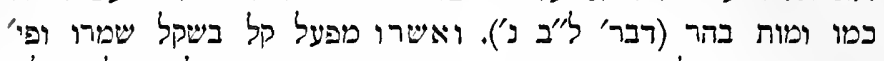

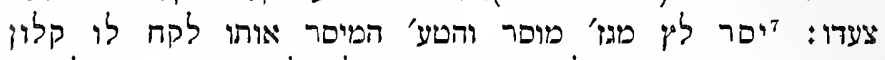

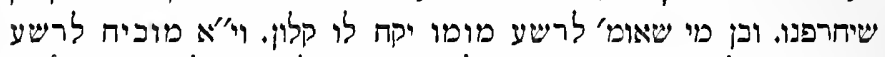

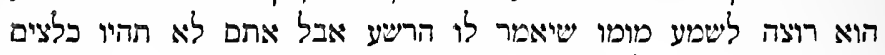

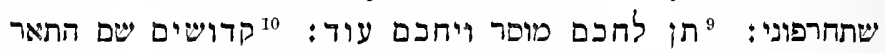

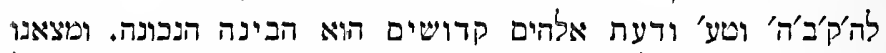

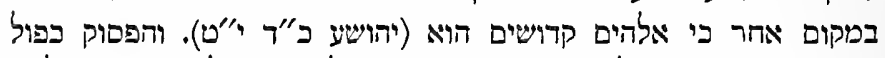

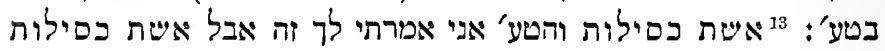

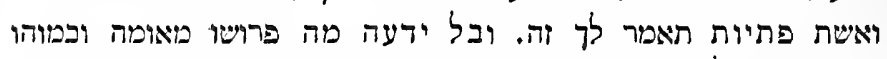

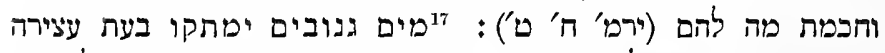

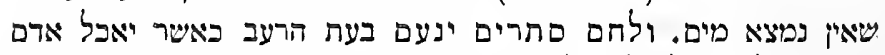

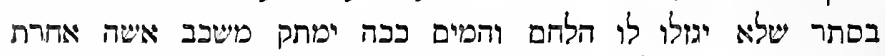

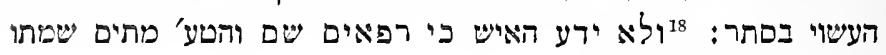
בפשעה קרואים שמרלה:

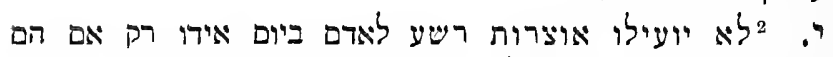

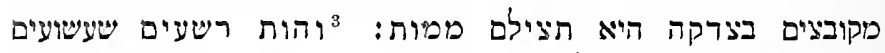

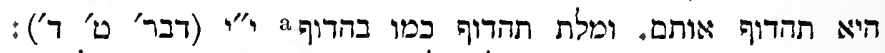

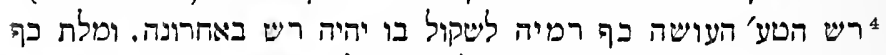

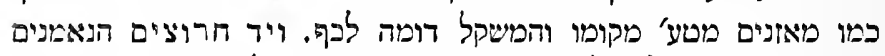

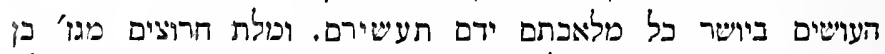

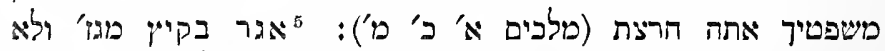

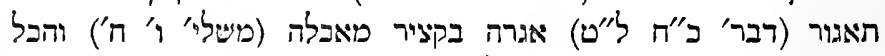

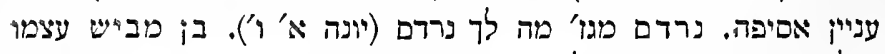

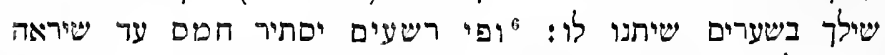

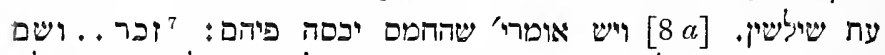

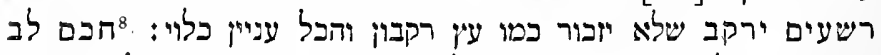

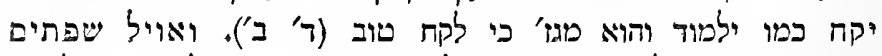

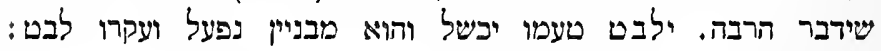




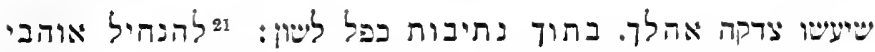

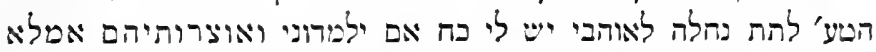

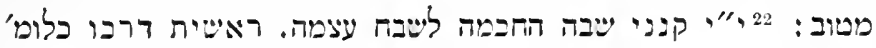

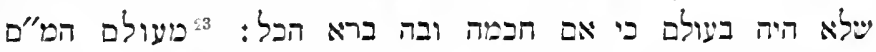

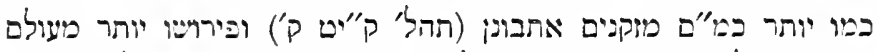

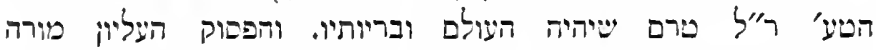

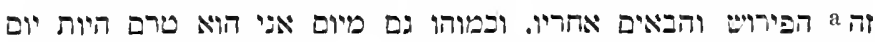

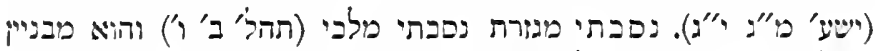

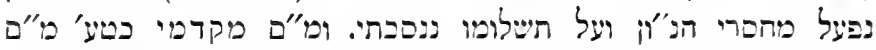

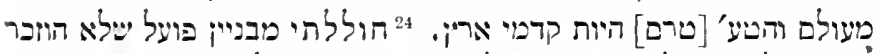

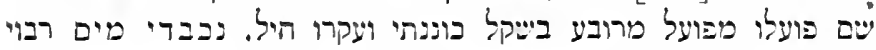

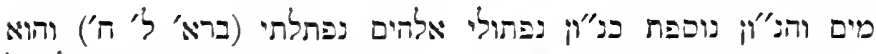

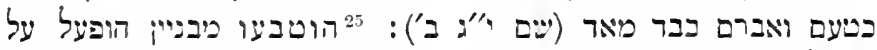

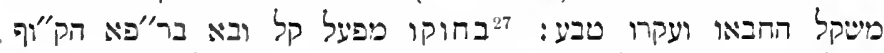

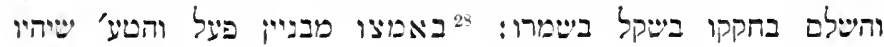

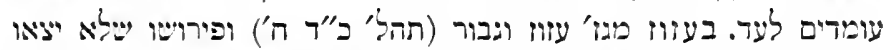

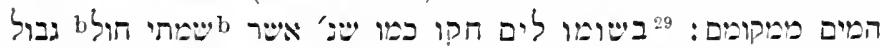

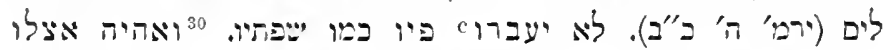

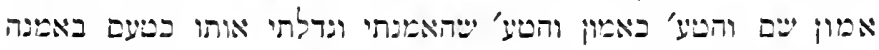

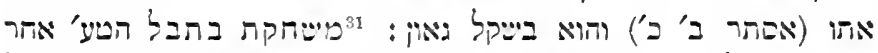

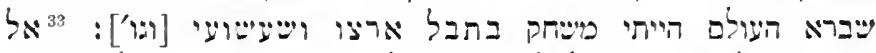

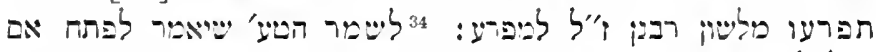

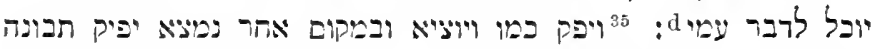

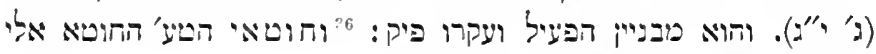

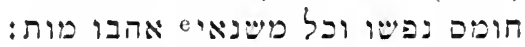

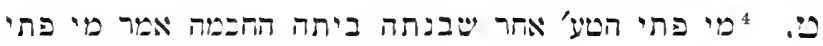

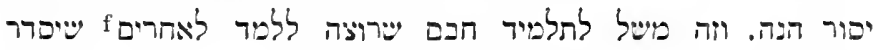

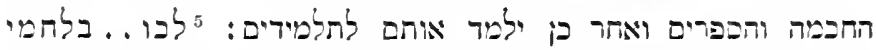

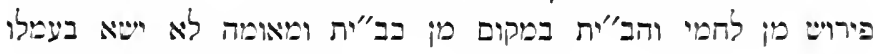

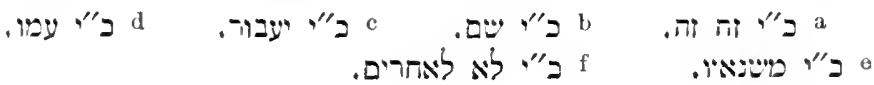




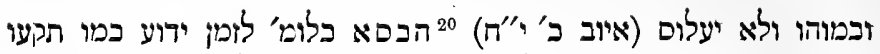

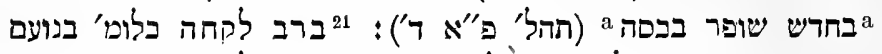

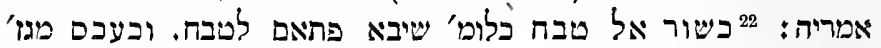

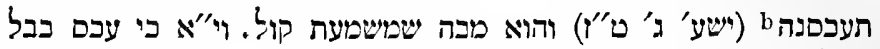

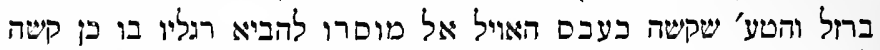

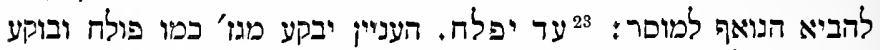

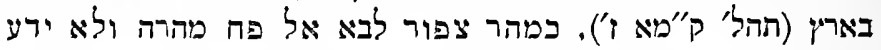

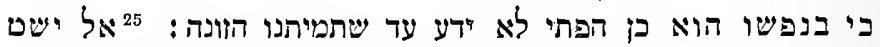

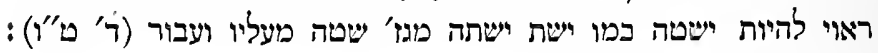

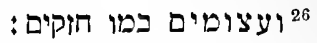

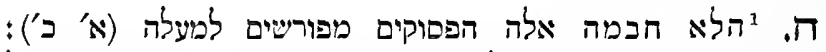

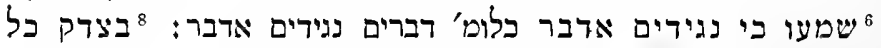

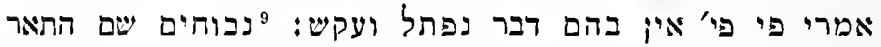

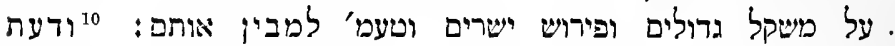

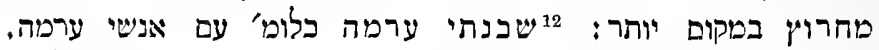

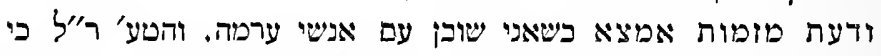

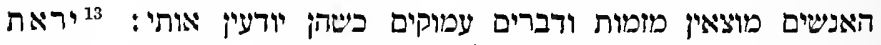

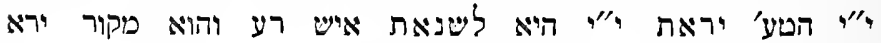

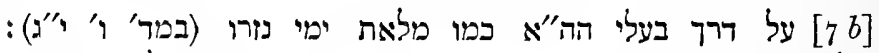

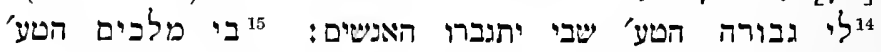

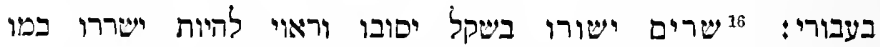

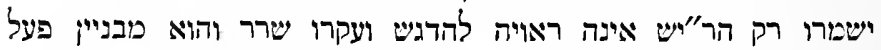

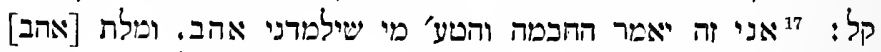

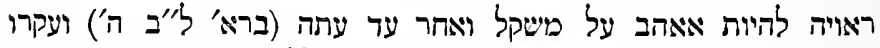

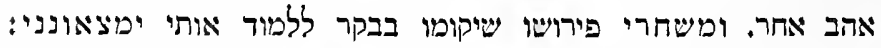

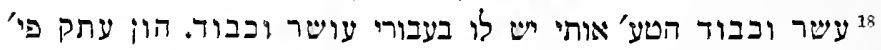

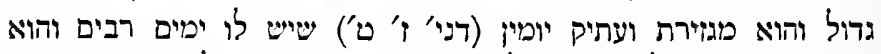

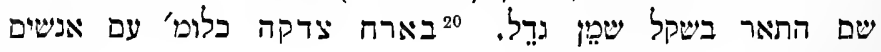

b שם כתב הראב"ע וו"ל ויש אומרי' כי b

a

העכמי' משמיעות קול: ביזר 


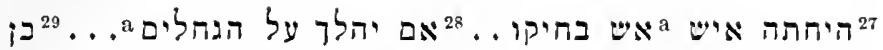

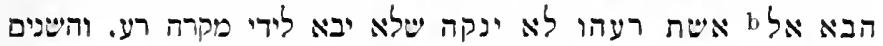

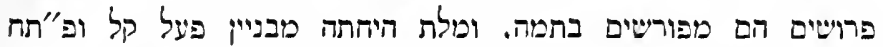

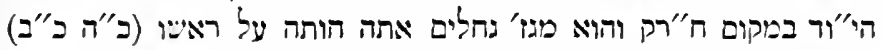

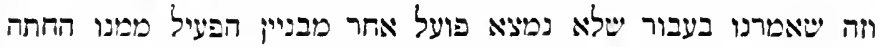

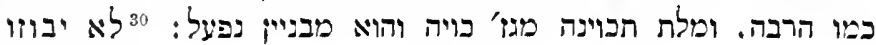

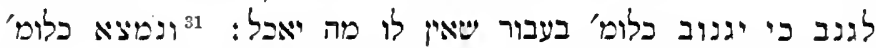

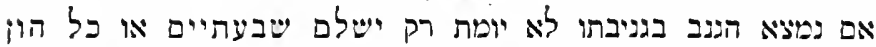

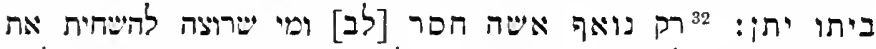

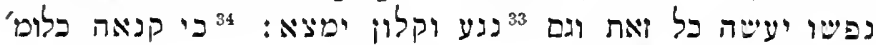

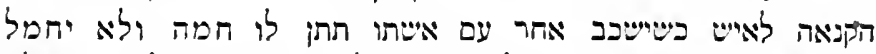

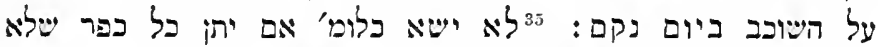

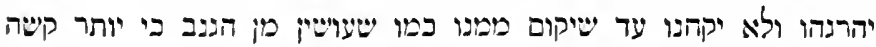
הניאוף מן הגנבה:

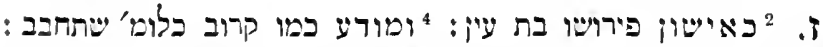

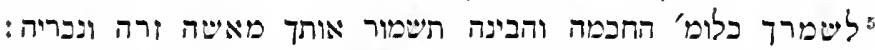

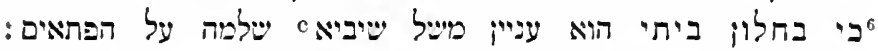

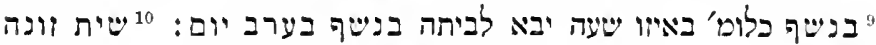

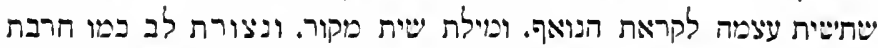

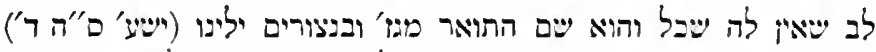

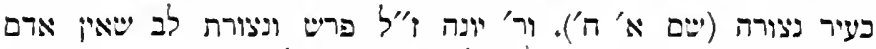

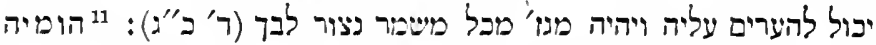

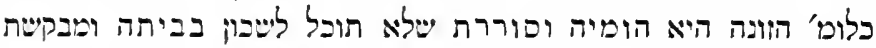
הנואפים:

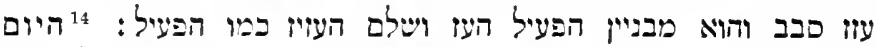

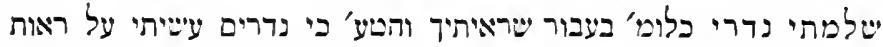

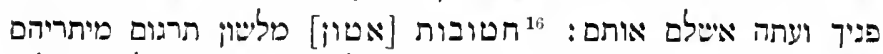

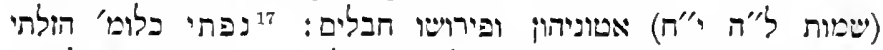

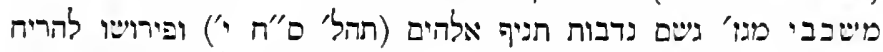
הסדינים ריה טוב : משם:

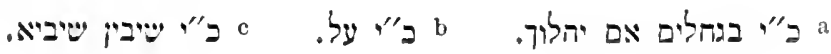




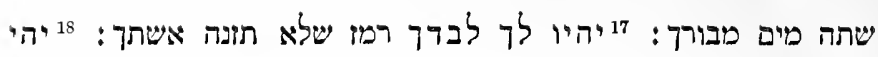

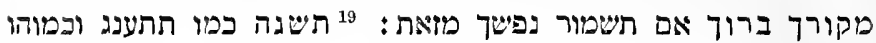

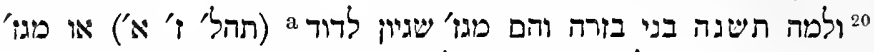

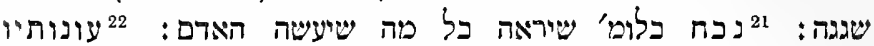

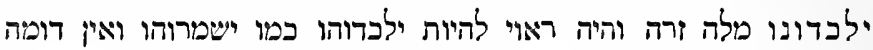

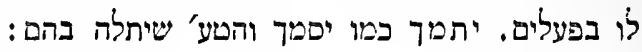
ר.

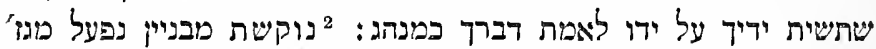

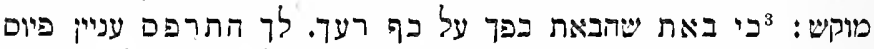

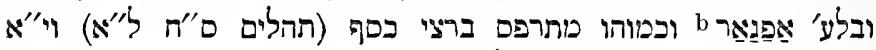

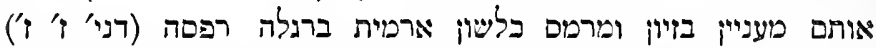

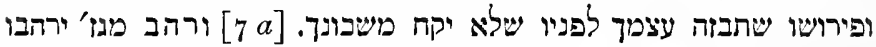

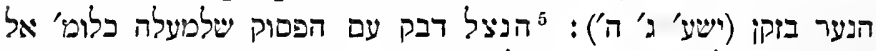

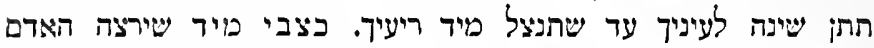

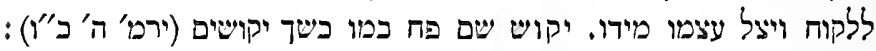

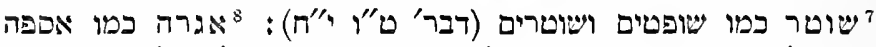

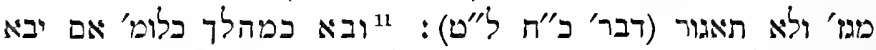

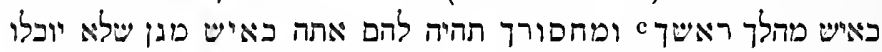

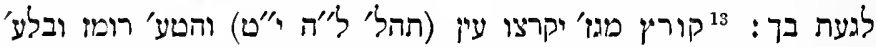

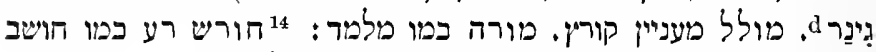

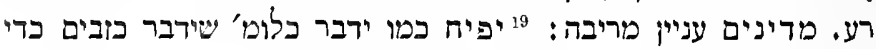

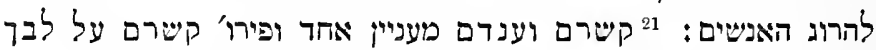

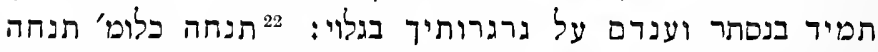

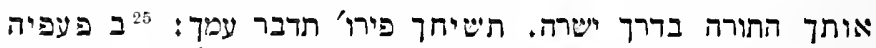

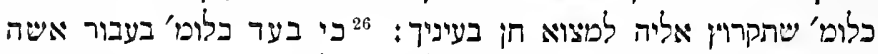

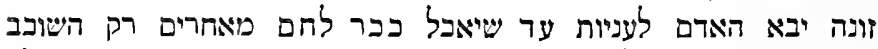

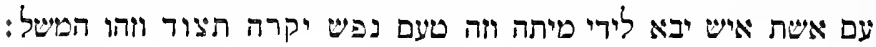

a שם כתב וו"ל ישי מפרשים בו תענוג כמו תשנה תמיד ויש אומרים

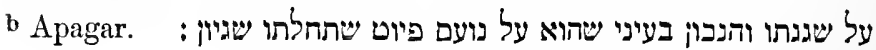
d Guiñar. c כ" כ"י רשך. 


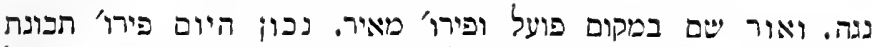

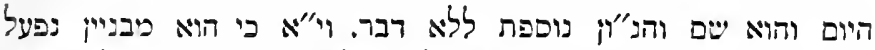

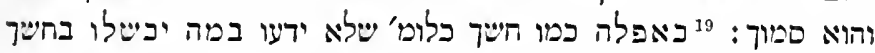

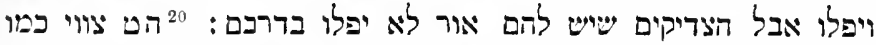

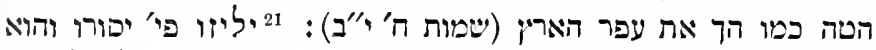

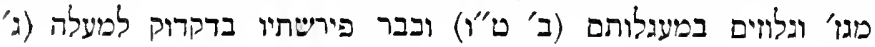

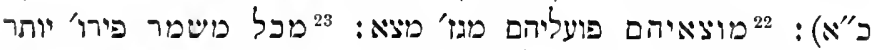

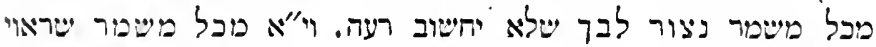

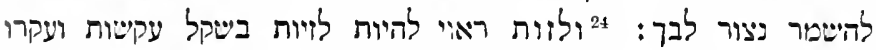

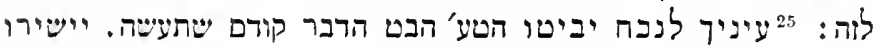

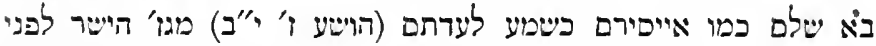

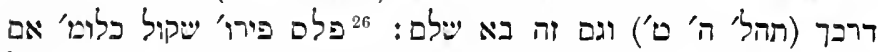

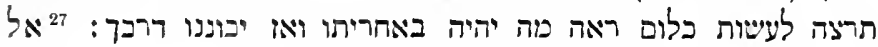

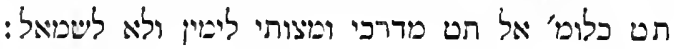

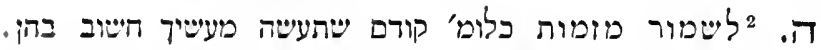

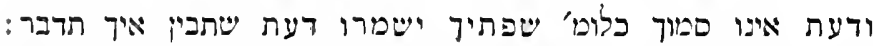

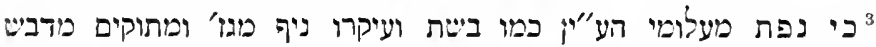

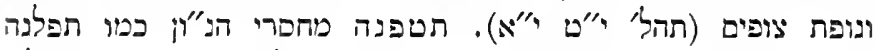

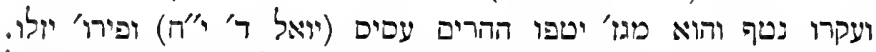

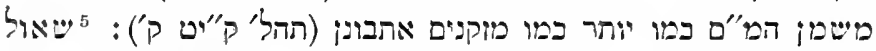

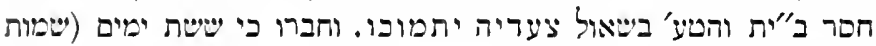

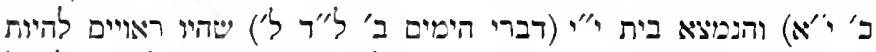

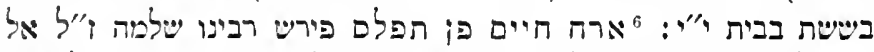

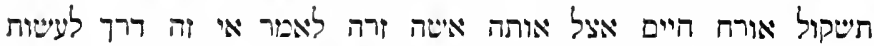

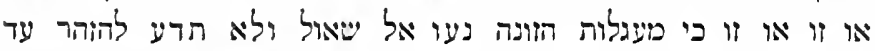

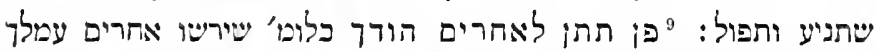

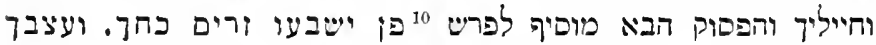

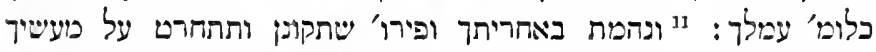

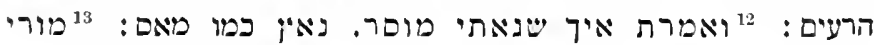
כמו מלמדי:

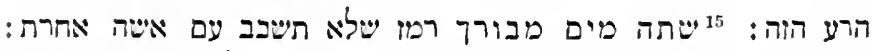

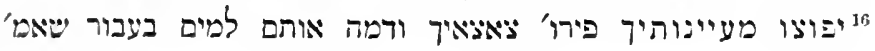


הוא ישמור רגלך. ומלת כסלך במו תקותך וכמוהו וישיטו באלהים בסלם (תהל' ע"ח ו'):

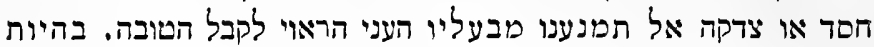

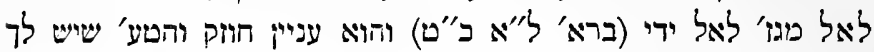

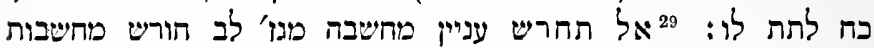
און (ו' יו"ח): [66]

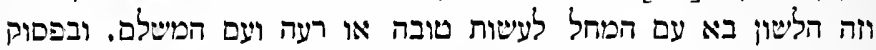

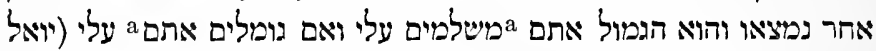
ד' ד'):

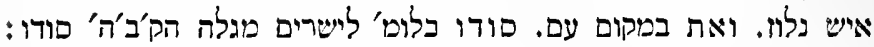

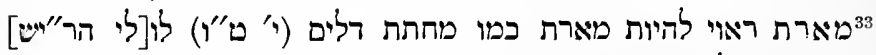

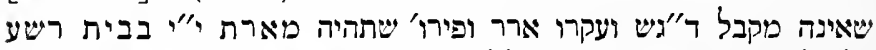

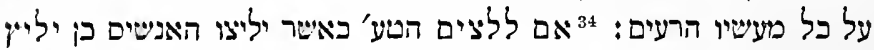
לחם הק'ב'ה' וחה כמו ילעג למו (תהל' ב' ד'ו'):

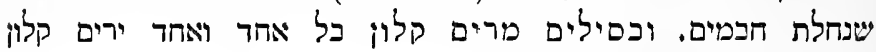
לעצמם והזא נחלחם:

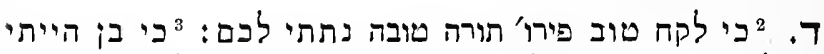

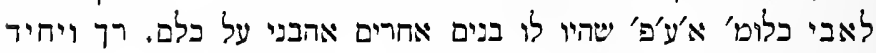

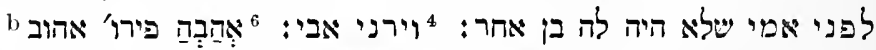

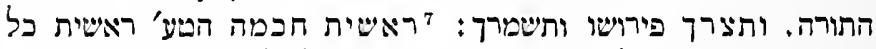

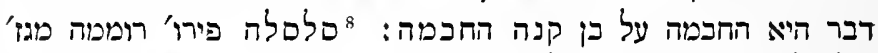

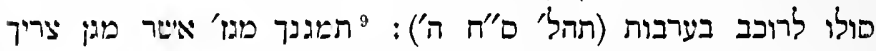

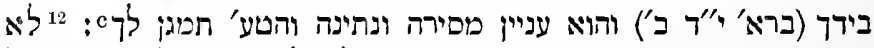

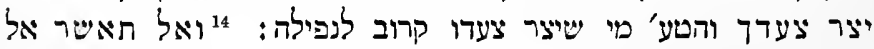

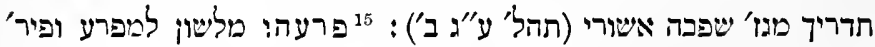

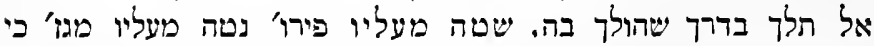
חשטה אשתו (במד' ה' י"ב):

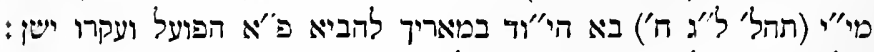

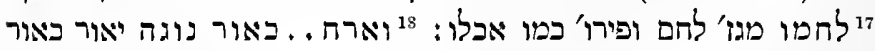

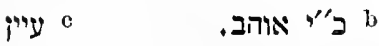

a כ"י משלמין , גומלין. שפת יתר ג"א. כ"אלמיו 


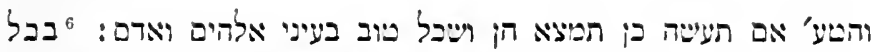

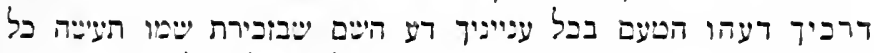

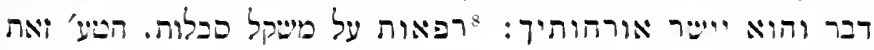

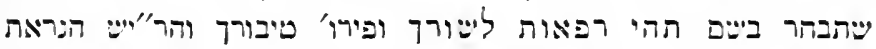

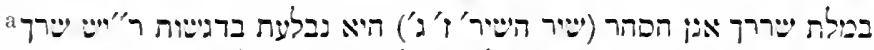

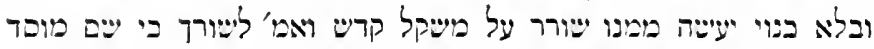

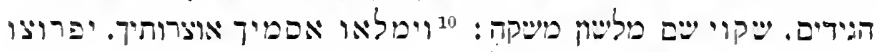

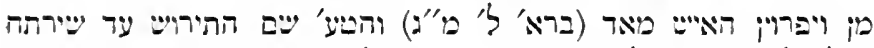

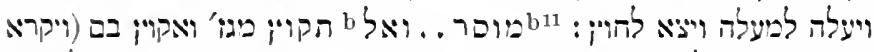

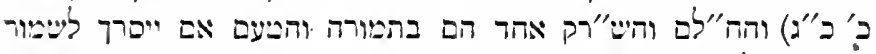
טצנותיו אל תמאם בתובהתו:

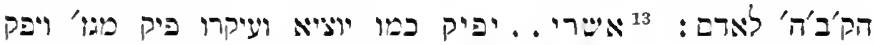

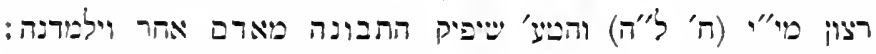

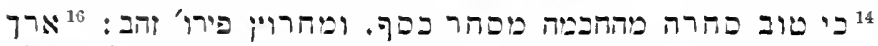

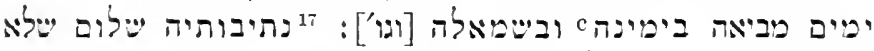

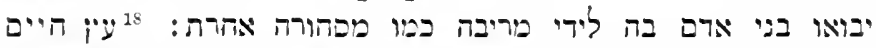

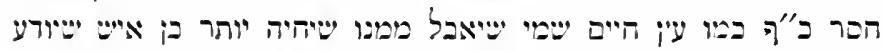

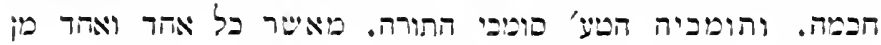

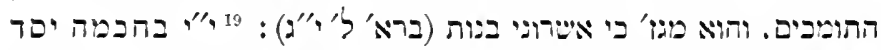

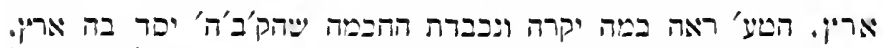

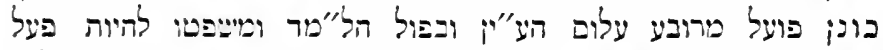

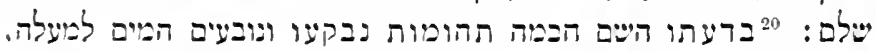

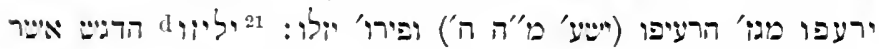

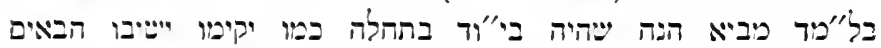

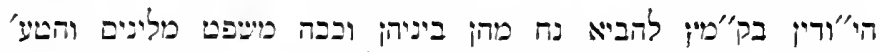

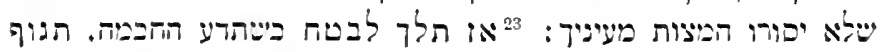

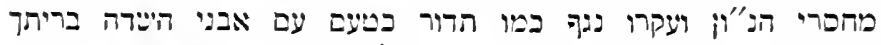

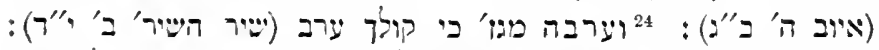

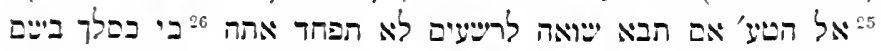

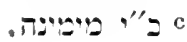

ב" ב"י אל טופר אל.

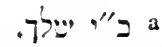

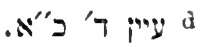




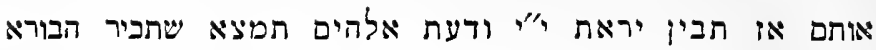

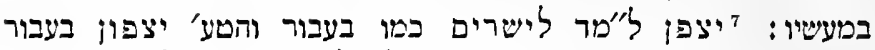

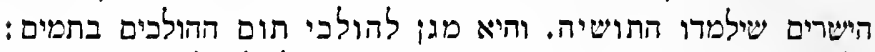

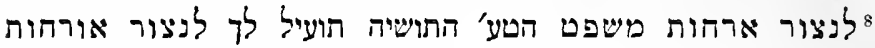
משפט. ודרך חסידיו ישמור השם [a

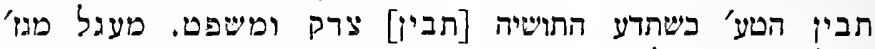

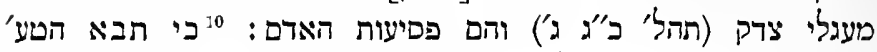

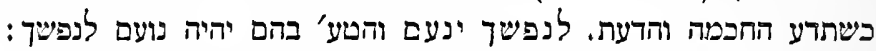

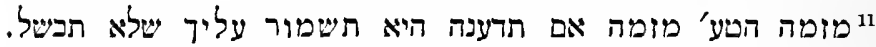

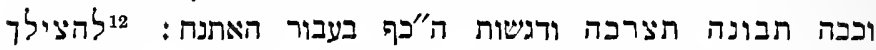

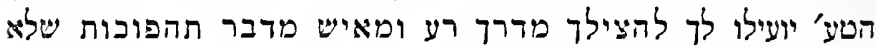

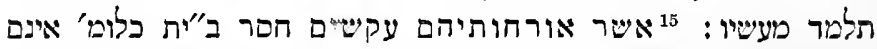

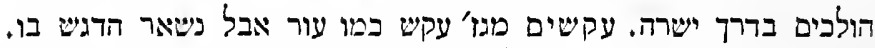

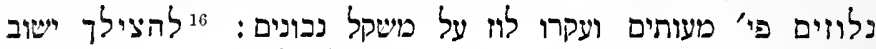

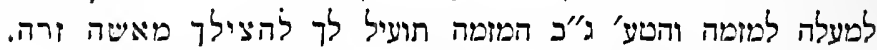
ונבריה כפול בטעם:

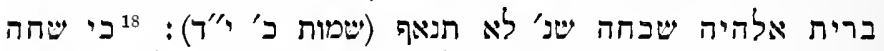

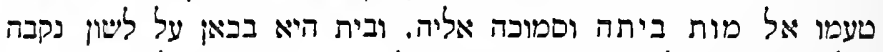

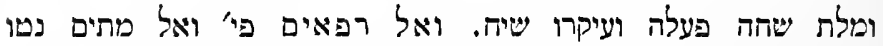

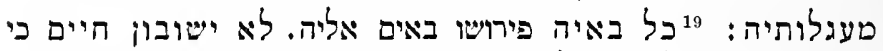

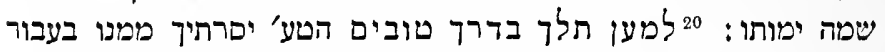

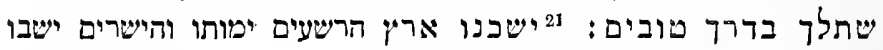

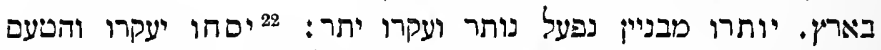

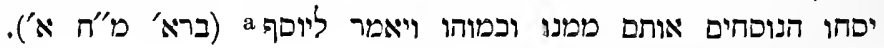

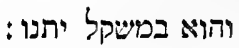

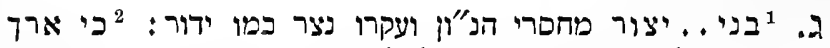

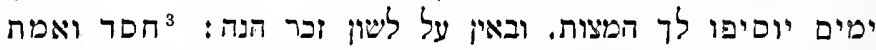

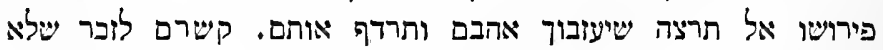

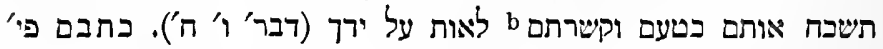

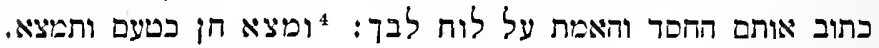


ב"ב ט"ו), אל תבא ללכח עמהם ועקרו אבה וראוי להיות תאבה לולי

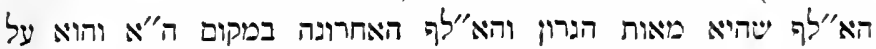

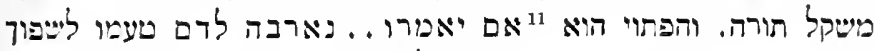

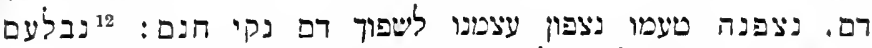

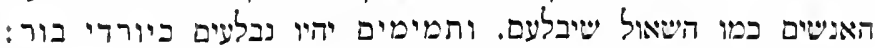
שיבל הון יקר גם וה מן הפתוי:

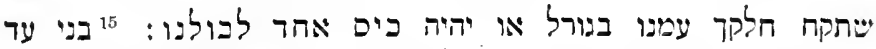

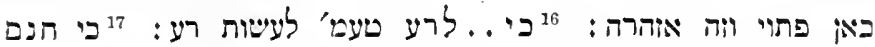

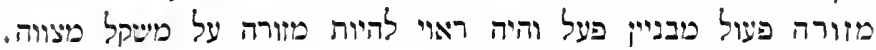

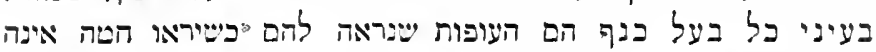

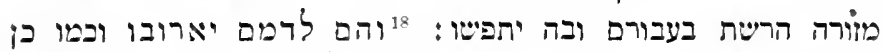

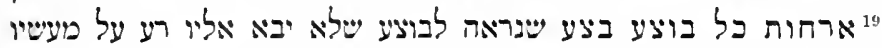

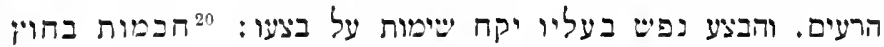

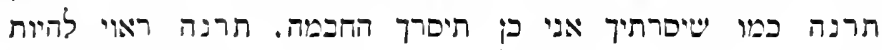

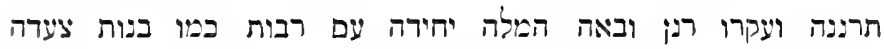
עלי שור (בריא' פ"ט כ"ב):

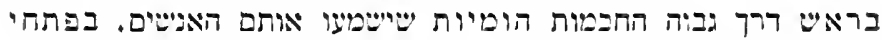

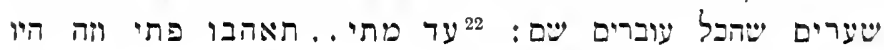

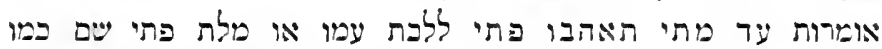

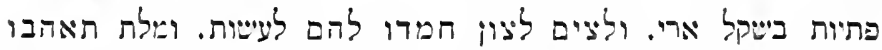

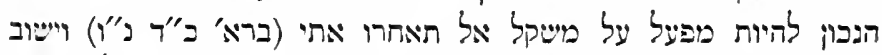
הפ"תח לי"רי a: אומר (תהל'י"ט ב'):

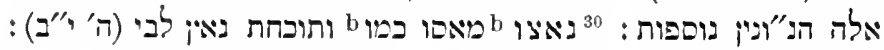

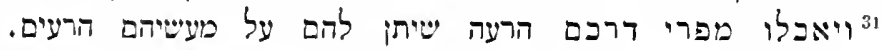
וממועצותיהם הרעות יישבעיו:

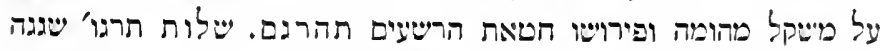

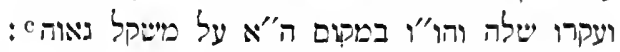

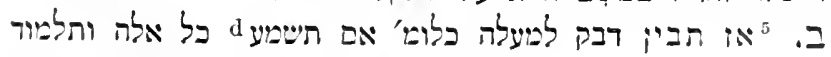

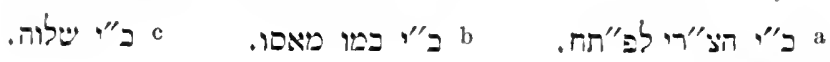

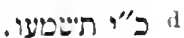




\section{פירושי פישלי \\ לר אברהם אבן עורא}

לורו

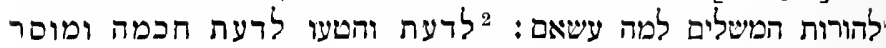

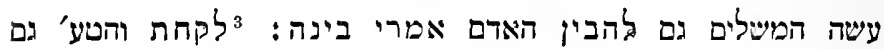

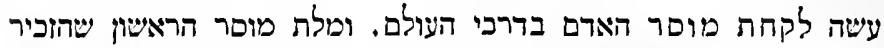

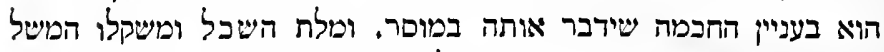

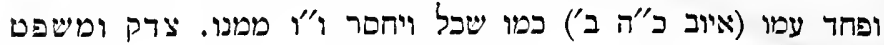

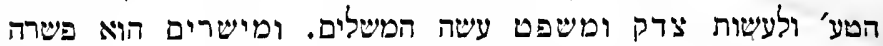

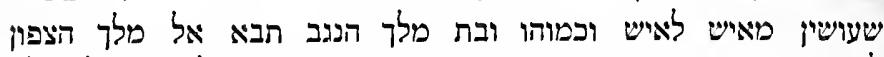

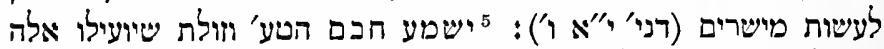

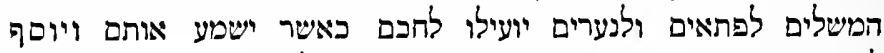

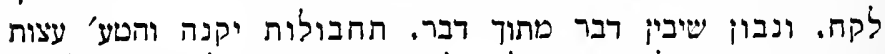

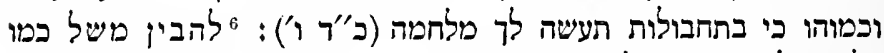

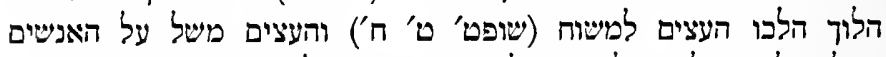

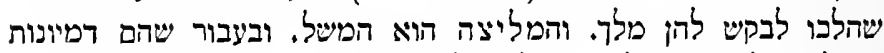

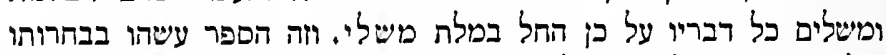

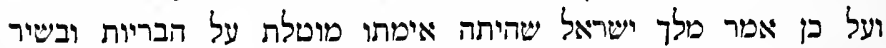

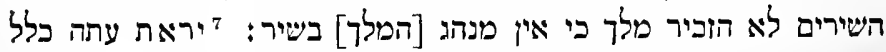

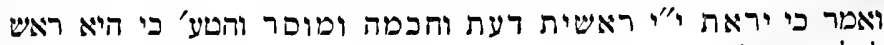

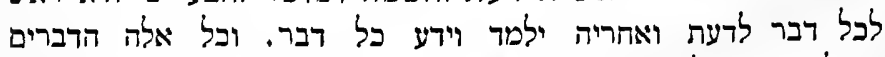

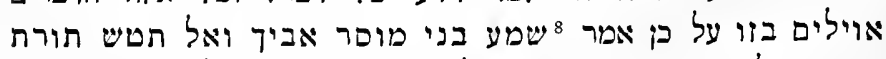

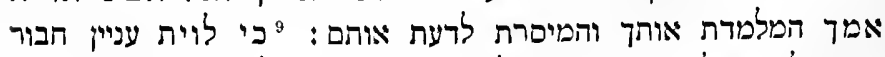

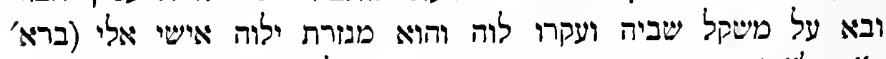

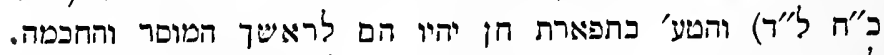

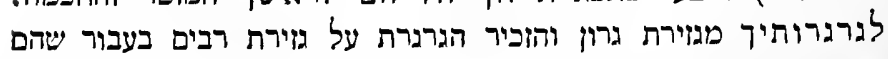
טבעות הרבה: 

פירוטש משלי

מיוחס בכ"י אוקספורד

לר' אברהם אבן עורא

הוצייאו ליאור

שמואל רולס דריבר

איקספורד

בבית דפוס הקלארנדון

$$
\text { שגה ה'ר'מ' לE"ק }
$$



פירוש פשלי 




\section{University of Toronto Library}

\section{DO NOT}

REMOVE

THE

CARD

FROM

THIS

POCKET

Acine Library Card Pocket Under Pat. "Ref. Index File" Made by LIBRARY BUREAU 
